\title{
El Símbolo de la Fe, ayer y hoy
}

Una introducción al «Símbolo de la Fe» debe iniciar por precisar el significado de la palabra inicial «símbolo», comúnmente usada para designar cualquier realidad tomada como figura representativa de un concepto: la bandera es símbolo de la patria, el color negro simboliza la muerte, etc. Uso general, por lo demás, enraizado en su acepción etimológica. Pues aquel vocablo proviene del respectivo griego «symbállein» (= juntar, fusionar, encontrarse, hacer un contrato), cuyo sustantivo «sýmbolon» significa principalmente no sólo «señal» $\mathrm{y}$ «distintivo», sino también «garantía» y «credenciales»; su significado conceptual más antiguo proviene de usos jurídicos previos a la escritura: dos o más partes de un objeto - moneda, sortija, bastón etc. - se distribuían entre otras tantas personas, siendo la coincidencia de aquellas partes «señal» o «garantía» de su reconocimiento como huéspedes, mensajeros o contratarios, quienes por ello tenían derecho a recibir una cosa, un privilegio u hospitalidad ${ }^{1}$. Con este significado fue usado el vocablo «símbolo» - desde el siglo III- por los Padres de la Iglesia ${ }^{2}$, para designar específicamente al Credo en cuanto «signo» de la fe cristiana ${ }^{3}$ : transmitido y explicado a los catecúmenos, para ser por ellos devuelto o solemnemente profesado como «garantía» de poseer el don de la fe, era confesado por los neófitos durante su regeneración bautismal, siendo luego diariamente profesado por los fieles como «reconocimiento» y «distintivo» de su vocación cristiana. El Símbolo era, pues, elemento insustituible de la gestación a la fe y de su profesión: el «signo» exigido por la Iglesia a los catecúmenos, el «sello» impreso en el corazón de los neófitos así como el «distintivo» y «credencial» de los ya fieles. De ahí su alcance.

1. Cf. H. Stephanus, Thesaurus linguae graecae, VIII, Graz 1954, 1045-49. 1058-72; H.G. Liddel-R. Scott, A greek-english lexicon, Oxford 1968, 1674-77; F. Corradini-J. Perin, Lexicon totius latinitatis, IV, Pavia 1940, 641. 2. El primero en usarlo fue San Cipriano (Epist. 69,7; 75,11: «Symbolum Trinitatis») y luego: Conc. Laodicea, Can. 4; San Ambrosio, Explan. Symboli, 1; Rufino A., Expos. Symboli, 2 etc.; San Agustín, De fide et symboli, I, 1.9.16; Serm. 56,1; 57,$2 ; 58,1 ; 212,1.2 ; 213,1.5 .7 .9 ; 214,1.8 .12 ; 215,5.9 ;$ Enchir. 7 etc. Al mencionado significado prístino del Símbolo se refieren expresamente: San Ambrosio (loc.cit.), San Agustín (Serm. $212,1)$ y San Ildefonso de Toledo, De cognit. baptismi, 33. 3. A este respecto, Cf. H-H. Carpenter, "Symbolum» as a title of the Creed: JThSt 43 (1942) 1-11; C. Eichenseer, Das Symbolum Apostolicum beim hl. Augustinus, St. Ottilien 1960, 9-41; V.H. Neufeld, The earliest christian confessions (NTTSt 5), Leiden 1963, 1-7; J.H. Emminghaus, art. Symbol: LThK, IX 1208-10 (bi- 


\section{Importancia del Símbolo}

Si el Padrenuestro sintetiza todo el mensaje central de Jesús y es la oración paradigmática de la Iglesia, mediante la que los hijos de Dios invocan, alaban y suplican, a su Padre celeste ${ }^{4}$, premisa necesaria e insustituible complemento de aquella plegaria es el Símbolo de la Fe. Pues, «¿cómo invocarán a aquél, en quien no han creído?» ( $R m$ 10,14a). Un resumen de esa fe - presupuesto esencial de toda plegaria cristiana - es precisamente el Credo, por ello consignado a los catecúmenos - en la Iglesia antigua y hodierna - antes de la Oración dominical, para que invoquen al Dios, en quien previamente han creído ${ }^{5}$. El Símbolo, en efecto, es:

\section{1) El compendio de la fe}

Así fue valorado siempre el Credo por la Iglesia: como la síntesis de la fe cristiana, la más lograda reunión o fusión (= «symbállein») de las verdades, que caracterizan la fe de la Iglesia. Como tal lo entendieron, por lo demás varios de sus más renombrados comentaristas antiguos, cuando le designan «la Fe» ${ }^{6} \mathrm{y}$, más exactamente, «la Fe santa y apostólica» ${ }^{7}$; pues el Símbolo es «el breviario de la fe» redactado por «los santos apóstoles», antes de separarse a evangelizar a todo el mundo, como "pauta de su predicación» ${ }^{8}$, siendo asimismo «la cifra» lograda o «sucinta fórmula de la fe» ${ }^{9}$ cristiana, por constituir «la breve pero grande norma de nuestra fe» ${ }^{10} \mathrm{o}$ «la síntesis de la fe católica» ", es decir, «la colección de todas las verdades de la fe» ${ }^{12}$ de la Iglesia o su

bliogr.); (i. Mainberger, Vom Zeichen zum Symbol: WuW 26 (1971) 413-21; J.M.D. Kelly, Early christian Creeds, London 31976, 52-61 (trad. españ., 71-81). 4. Cf. S. Sabugal, El Padrenuestro, Salamanca 1982; Id., Abba... La Oración del Señor, Madrid 1985 (bibliogr.). 5. Cf. San Agustín, Serm. 56,1; 57,1; 58,1; 59,1; 214,1; S. Congregación del Culto, Rituale Romanum. Ordo initiationis christianae adultorum (Ciudad del Vaticano 1972), Nos. 183-192; Cf. a este respecto, infra. 21.39ss. 6. San Cirilo J., Cat. V 12; XV 2; Cf. XIII 32; XIV 24.27; XVIII 26.32; Teodoro Mops., Hom. II 4; San Pedro Cris., Serm. 56 (PL 52,355C.356C). 57 (Ib. 360B). 58 (Ib. 361A). 59 (Ib. 362C). 60 (Ib. 365C. 366A). 61 (Ib. 369A). 62 (Ib. 373A); San León M., Hom. 24,6; Epist. 165,3 [ = «la Fe católica»]; Eusebio C., Hist. Eccl., V 28,13; San Basilio M., Epist. 51,2 ; etc. Es pues probable que la designación primitiva del Símbolo fuese «La Fe»; así con F. Kattenbusch, Das Apostolische Symbol, II, Leipzig 1900, 509. 7. San Cirilo J., Cat. XVIII 32. 8. San Ambrosio, o.c., 1. La brevedad y el origen apostólico del Símbolo es subrayado también por: Nicetas de Remesiana, Explan. Symboli, 13; Rufino A., o.c., 2; San Máximo T., Hom. 83 (PL 57,333A); San Ildefonso T., De cogn. bapt., 32; Cf. a este respecto F. Kattenbusch, o.c., II 9-17. 9. San Agustín, Serm. 58,1; 212,2; Cf. Serm. 212,1; 213,1. El Símbolo es «un inagotable tesoro en breves palabras de comprender» (Teodoro M., Hom. I 7) o «la perfecta profesión de la fe», y «la enseñanza sin ambigüedad alguna»: San Juan Cris., Cat. baut., V 19. 10. San Agustín, Serm. 59,1. 11. Id., De fide et symbolo, I 1; Cf. también Teodoro M., Hom. I 7; II 4. En el Símbolo, expresión de nuestra fe y con el que «bautizamos en la Trinidad consustancial», están «resumidos en pocas palabras todos los testimonios» sobre «lo que la Sagrada Escritura dice del Padre, del Hijo y del Espíritu Santo» (San Basilio, De fide, 3-4); pues los apóstoles, «recogiendo testimonios de todas las Escrituras Sagradas, formaron este único y breve edificio de la fe», de modo que «en el Símbolo está consignada para los fieles la fe católica»: San Ildefonso T., De cogn., bapt., 32.35. 12. Sto. Tomás A., Summa Theol., II-II, 
acertado «compendio» ${ }^{13}$, en aquél expuesta y concentrada con brevedad e ilación insuperables. La confesión de aquella fe es, pues, signo y garantía o credencial ( = «sýmbolon») del verdadero creyente en Jesucristo, por ser el Símbolo «la señal de la fe» ${ }^{14}$ cristiana o «la carta de fundación de nuestra Sociedad», de modo que «en quien lo profesa se reconoce a un fiel cristiano» ${ }^{15}$. Por «el signo del Símbolo», en efecto, se distingue aquél del «extraño a la fe y del enemigo de la Iglesia» ${ }^{16}$, cualificándose a la vez como verdadero y legítimo hijo suyo: ¡en la confesión del Credo, - «precioso compendio de la fe de la Iglesia» ${ }^{17}$ y unitario documento de nuestra $\mathrm{fe}^{18}$-, se diferencia tanto del pagano como del hereje y cismático el miembro genuino del Cuerpo místico de Cristo! El verdadero cristiano, en efecto, se caracteriza y distingue no sólo de cualquier otro hombre religioso sino también de los que «naufragaron en la fe» cristiana o «se desviaron de ella» $(1 \operatorname{Tim} 1,19 ; 6,10)$ y, por ello, son «descalificados en la fe» $(2 \mathrm{Tim} 3,8)$ que justifica y salva $(\mathrm{Rm} 3,28 ; 10,9-10)$, por llevar impresa en su espíritu -y testimoniada en su propia historia- la marca o «señal de la fe» bautismal y ortodoxa, condensada en las verdades teológicas o dogmas del Credo. Pues el Símbolo es asimismo:

\section{2) La síntesis de la teología}

Resumen o breviario de la fe cristiana, el Credo es efectivamente también -y por ello- la cifra del esfuerzo racional por entenderla — «fides quaerens intellectum»- o de su reflexión teológica, el más apretado compendio de la dogmática de la Iglesia ${ }^{19}$ : en él están resumidos todos los dogmas centrales del

1 8; el gran teólogo precisa seguidamente, que «los artículos de la fe... están reunidos debidamente en el Símbolo», de modo que «no hay en él nada inexacto» (Ib., I 9). De ahí que en su Exposición del Símbolo de los Apóstoles condensa la explicación de toda la teología cristiana: Cf. infra, n. 19. 13. Catecismo Romano, I 12,1 («fidei nostrae summa»). Así lo designó también, unos años antes, M. Lutero (Der grosse Katechismus [a. 1529]: «Luthers Werke», XXX.1, Weimar 1910, 192: El Credo es «la suma» de la fe) y J. Calvino, Institution de la foi chrétienne, II, XVI 5: El Símbolo de los Apóstoles es «el sumario de la fe» cristiana. 14. Rufino A., o.c., 2; Cf. San Ambrosio, o.c., 1; San Ildefonso T., o.c., 33. 15. San Agustín, Serm. 214,12; Cf. Serm. 212,1; San Máximo T., Hom. 83 (PL 57, 444A); San Ildefonso T., o.c., 33. 16. San Máximo T., Hom. 83 (PL 57, 433A-B). El Símbolo es, pues, «la regla de fe ortodoxa»: San Ildefonso T., De cogn. bapt., 31. 17. J.N.D. Kelly, art. Apostolisches Glaubensbekenntnis: LThK, I 762. 18. Cf. H. de Lubac, La foi chrétienne. Essai sur la structure du Sumbole des Apôtres, París 1969, 223-254. 19. Así lo entendió ya San Agustín, compendiando prácticamente todas las verdades de fe cristiana en el comentario al Símbolo de su obra (a.421) Enchiridion, 9-113. Siguieron su pauta luego dos de los teólogos antiguos más grandes de la Iglesia: Según Sto. Tomás de Aquino, el Símbolo contiene todas las verdades de la fe de la Iglesia (Cf. Sum. Theol., II-II 1,8-9) o «la íntegra verdad de la fe» (Ib. 1,10 ad 3), condensando por ello su Exposición del Símbolo de los apóstoles («Opuscula Theologica», II, Roma 1954, 193-217) la explicación de todas las verdades fundamentales de la dogmática cristiana [ = teología, cristología y soteriología, mariología, pneumatología, eclesiología y sacramentología, escatología], pudiendo por ello ser designado aquel comentario al Credo una mini-Suma Teológica; análoga convicción abrigó san Buenaventura, cuyo Breviloquio es en realidad una exposición de toda la teología cristiana a raíz de los artículos del Credo, desde la fe en Dios (I 1-9) hasta la creencia en «el juicio» y en «la gloria 
cristianismo sobre el Dios uno y trino así como sobre la creación, redención y santificación, formulados en torno al «Símbolo de la Trinidad» ${ }^{20} \mathrm{o}$ a la profesión de fe «en un solo Dios «padre» y «en un solo Señor Jesucristo» y «en el Espíritu Santo». Ésa es, en efecto, la estructura literaria y teológica -esencialmente ternaria y trinitaria- del Credo ${ }^{21}$. Su confesión trinitaria constituye, por tanto, como el sólido tronco del árbol de la fe, del que nacieron y en el que se alimentan e incesantemente se renuevan las ramas fructíferas de las verdades, que integran la dogmática cristiana. La cual, por lo demás, también se enraiza en el Símbolo. La reflexión teológica del cristianismo, en efecto, surgió y se fraguó en torno a la confesión trinitaria, como renovado y tenaz «empeño por conservar» y desarrollar «la única fe» cristiana en «un solo Dios y Padre», así como en «un solo Señor» Jesucristo y en «un solo Espíritu» (Cf. Ef 4,3-6), nutriéndose por tanto en el humus de aquella Confesión tanto «la fe que busca inteligencia» como «la razón iluminada por la fe». $L a$ teología de la Iglesia hunde, pues, sus raíces en el fecundo subsuelo del Símbolo: de él se nutre y en él se consolida. Por lo demás, la reflexión teológica progresa o avanza también en la medida de su fidelidad al Símbolo: «Pauta de la predicación» cristiana y «breve pero grande norma de nuestra fe» así como síntesis de la dogmática de la Iglesia (Cf. supra), el Credo es asimismo - y por ello- no sólo guía experto de la reflexión teológica sino también garante o sendero seguro de su progreso. Pues quienes «se descarriaron en la fe» ortodoxa y perseveran en su descarrío «no avanzaron más» (2Tim 3,8b-9a) por la

del paraíso» (VII 1-7). Como síntesis teológica valoraron también el Símbolo, sin duda tanto los dos grandes reformadores protestantes - M. Lutero y J. Calvino- como el Catecismo Romano, al designarle respectivamente «la suma» de la fe o «el sumario de la fe» y «la suma de nuestra fe» (Cf. supra, n. 13). Y en esta línea se sitúa también uno de los primeros teólogos protestantes, cuando (a. 1557) afirma que «los Símbolos» contienen «brevemente sintetizada la suma de la doctrina» cristiana: PH. Melanchton, Prefacio a la Enarratio Symboli niceni de C. Cruciger: «Corpus Reformatorum», XXIII (Brunschwig 1885) 196-346: 197. Análogamente se expresó un gran conocedor de los antiguos dogmas cristianos y pionero de la moderna investigación del Símbolo, cuando afirma que su «explicación teológica, en el curso de la historia, coindice evidentemente con el desarrollo de la dogmática y de la teología» (A. Harnack, Apostolisches Symbol: RE I 74155:755). De modo más explícito y del todo acertadamente, pues, el mayor teólogo protestante de nuestro siglo afirma, que la Dogmática es «la explicación del Credo»: K. Barth, Credo. Die Hauptprobleme der Dogmatik dargestellt im Anschluss an das Apostolische Glaubensbekenntnis, Zollikon-Zürich 1946, 11. Análogo sentir abrigan los teólogos y patrólogos católicos, cuando afirman que «los más importantes» Símbolos «expresan la fe de la Iglesia», por «contener... la fe divina y católica y subrayar [sus artículos] la importancia central de estos dogmas en la economía de la salvación» (P. Franzen, Glaubensbekenntnis. I: LThK IV 935-38:937), siendo por ello «el Símbolo de los apóstoles» valorado acertadamente como «un resumen de las principales doctrinas del cristianismo» así como «un compendio de la teología de la Iglesia»: J. Quasten, El Símbolo de los apóstoles: «Patrología», I, Madrid 21968, 32-38:32 (Sobre la importancia dogmática del Símbolo, Cf. P. Franzen, a.c., 937s). Si esto es exacto, los diversos tratados teológicos deberían -en asonancia, por lo demás, con su renovación requerida por el Conc. Vat. II, (Cf. Decr. OT 17)- ser reorganizados, de modo que reflejen en su misma ordenación o secuencia la unitaria estructura trinitaria del Símbolo: Cf. infra, 29. 20. San Cipriano, Epist. 75,11. 21. Cf. infra, 48-52. 
senda de la teología, asegurando por el contrario la fidelidad al Símbolo el éxito final o madurez de toda reflexión teológica. Y esto, por su estrecha relación con el Credo de la Iglesia. En efecto, si aquélla reanuda constantemente el esfuerzo por entender las verdades dogmáticas, contenidas en sus artículos, es con el fin de acercar al hombre de su tiempo hasta el sagrario de sus misterios salvíficos. De ahí que todo progreso teológico es, en rigor, un avance hacia la plena inteligencia del Credo, cuya hermenéutica - isiempre necesaria! - equivale por tanto a la interpretación de los centrales dogmas cristianos. Es, pues, normal que el grado de fidelidad o infidelidad a ese insustituible origen y raíz de la teología cristiana o de la dogmática de la Iglesia condicione decisivamente tanto la ortodoxia de la fe como la solidez y talla de toda reflexión teológica, genuinamente cristiana: si la herejía es fundamentalmente infidelidad racional a una o varias verdades del Símbolo, la ortodoxia teológica se caracteriza esencialmente por la lealtad de la razón al «depósito» de la fe (1Tim 6,20; 2 Tim 1,12.14) concentrado en sus artículos, determinando asimismo el grado de esa lealtad tanto la endeblez como la embergadura de todo pensamiento, reflexión y expresión verdaderamente cristianos. El Símbolo, en efecto, es:

\section{3) El eje del cristianismo}

En el «olivo» de la Iglesia (Cf. Rm 11,16-24) es el Credo como el tronco, del que se nutren y por el que fructifican las «ramas santas» de los miembros de aquélla, cuya «casa» o «templo de Dios» (1Cor 3,9-17) se sostiene asimismo por la columna maestra del Símbolo. ¿No se mantiene erguido un cuerpo por la cohesión de sus huesos y vértebras con el eje de su columna vertebral?: «el Cuerpo» de la Iglesia (1Cor 10,17; 12,12-27; Rm 12,4-5), enriquecido por el Espíritu de Dios con diversidad de carismas (1Cor 12,4-11.28-30; Rm 12,6-8; Ef 4,11-13) y animado por ese mismo Espíritu del Señor, - su Cabeza-, se mantiene erguido por la cohesión de la fe de sus miembros con las verdades centrales de aquélla, sintetizadas en el Símbolo. Por ello es éste la esencia del Cristianismo, la «síntesis de su contenido esencial» ${ }^{22}$. En efecto, toda la multisecular historia de la cultura y civilización cristiana, - de su filosofía y teología, de su literatura y arte, de su acción evangelizadora y pastoral, incluso de su investigación científica-, es en realidad el despliegue histórico del Símbolo: el renovado intento de la Iglesia por explicar y reinterpretar, para el hombre de su tiempo, alguna o varias de sus verdades dogmáticas. Las cuales, por ello, sellaron y sellan profundamente la cultura y civilización genuinamente cristianas. Éstas son, pues, inseparables del Símbolo: sólo a su luz pueden ser objetivamente valoradas, rectamente interpretadas y eficazmente renovadas. Lo que significa: sin el Credo, la historia del cristianismo sería un indescifrable enigma. Más aún: de aquél no quedaría más que un montón de

22. J. Ratzinger, Einführung in das Christentum, München 1968, 25 (trad. españ., Salamanca 1971,29$)$. 
ruinas, si eliminásemos de su historia los artículos del Símbolo. ¿Qué subsistiría, por ejemplo, del arte y literatura cristianos, sin las verdades centrales del Credo? ¡Nada o casi nada! Pues a la consistencia y cohesión de aquellas verdades dogmáticas se debe, por lo demás, el que la civilización y cultura cristiana hayan resistido victoriosamente a los frecuentemente destructores embates del tiempo. Éstos aniquilaron efectivamente grandes empresas humanas, hundieron en la sombra del olvido numerosos y fuertes imperios, sofocaron multiseculares y arraigadas religiones así como sólidas ideologías, redujeron a restos arqueológicos o a documentos históricos civilizaciones y culturas florecientes... Si fracasaron, sin embargo, ante la civilización y cultura cristiana, si no lograron enmudecer la voz de la Iglesia ni detener su acción benéfica, se debe principalmente - sin duda - al hecho de estar cimentadas sobre la sólida «roca» (Mt 7,24-25par) del Símbolo de la Fe, verdadero eje central de la historia cristiana. Ya la historia de Israel recibió de la fe su impulso primitivo y su orientación posterior: «Por la fe... fue creado el universo» y agradó «Abel a Dios» y «fue trasladado Henoc» y «construyó el arca» Noé; también «por la fe obedeció Abraham» a la vocación de Dios «y salió» de su casa «y peregrinó por la tierra prometida» y «presentó a Isaac como ofrenda», recuperándolo "para que fuese figura» de Cristo resucitado; «por la fe bendijo Isaac a Jacob» y éste «a cada uno de los hijos de José», quien «por la fe... evocó el éxodo de los hijos de Israel», realizado mediante Moisés «por la fe»; por ésta conquistaron aquéllos la tierra prometida y «sometieron reinos» e «hicieron justicia» tanto «Gedeón, Barac, Sansón y Jefté» como «David, Samuel y los profetas», animados por la misma fe, que vigorizó luego a los mártires de Israel, «alabados todos ellos por su fe» aun «sin haber conseguido el objeto de las promesas» (Cf. Hebr 11,3-39). Realizadas éstas en el «nuevo Israel», quien asimismo nació y se puso en marcha, a impulsos de la fe condensada en el Símbolo. La Iglesia, en efecto, surgió al renacer «del agua y del Espíritu» (Jn 3,5) quienes fueron bautizados «en el nombre del Padre y del Hijo y del Espíritu Santo» (Mt 28,19), es decir, confesando la fe en el Dios uno y trino. Y a la fuerza, conferida por esa fe, se debe principalmente la predicación eficaz de sus evangelizadores, — «icreemos, por eso hablamos!» (2Cor 4,13)-, el testimonio valiente de sus mártires, la enseñanza cristalina de sus maestros y el celo de sus pastores, la cálida intuición de sus místicos, la gigantesca obra de sus misioneros, la fecunda inspiración de sus artistas y, sobre todo, la vida ejemplar de sus santos. Pues el Símbolo de la Fe es:

\section{4) La espina dorsal del cristiano}

La espiritualidad de éste, en efecto, está forjada en el contenido de la fe sintetizada en el Credo: si mediante la explicación de sus artículos educó y educa la Iglesia en la fe cristiana a los catecúmenos (cf. infra), también en la catequesis de niños y de adultos ocupa - idebe ocupar! - el Símbolo un puesto central (cf. infra), alimentando asimismo los fieles su fe en el Credo, por 
ellos recitado - desde el s. VI- durante la celebración de la eucaristía ${ }^{23}$, como sostén de su existencia cristiana. La vivencial confesión del Símbolo, efectivamente, robustece la espiritualidad del cristiano y supera sus crisis de fe, haciendo del creyente «no una caña zarandeada por el viento» (Mt 11,7par) de los sucesos y pasiones, sino un robusto «árbol bueno» (Mt 7,17par) y, más aún, un «hombre nuevo» (Ef 2,24). A ese «hombre en Cristo» (2Cor 12,2) y «hombre de Dios» (1Tim 6,11) o creyente adulto se refería sin duda san Pablo, en su exhortación a los fieles de Corinto: «iMantenéos firmes en la fe! ¡Sed hombres!» (1Cor 16,13). No hay duda: la estatura del «hombre nuevo» se mide por la talla de su vivencia del Símbolo, la cual hace del catecúmeno un fiel cristiano y, más aún, del neófito un adulto en la fe. Y es que sólo la vivencia del Símbolo o la fidelidad a la fe, -condensada en el Credo de la Iglesia-, hace del creyente inicial un espiritualmente adulto: sólo aquella vivencia del Símbolo, traducida en confesión pública da cohesión a los eventos de su vida y mantiene erguido el edificio de su historia, haciendo de la existencia cristiana una «antorcha» (cf. Fil 2,15) o «la luz» que ilumina al mundo con el amor de sus «buenas obras» (Mt 5,14-16); sólo la experiencia personal del Credo hace asimismo del cristiano «la sal», capaz de salar con el amor «la tierra» (Mt 5,13) y, también, la «levadura», que puede - con el amor- «fermentar toda la masa» (Mt 13,33par) de los hombres. ; La vivencia del Símbolo garantiza -sólo ella - tanto la santidad personal como el testimonio del verdadero creyente en Jesucristo!: De quien, mediante la fe justificado (Gál 3,8; $\operatorname{Rm} 3,26-28)$ y salvado (Ef 2,8), está «cimentado en la fe» (2Cor 1,24; Col $1,23)$ del Credo, por ella camina $(2$ Cor 5,7$)$ y en ella progresa $(2$ Cor 10,15$)$, combatiendo diariamente «el buen combate de la fe» (1Tim 6,12). Para esto necesita naturalmente aquél una protección o salvaguardia. Y eso es también el Símbolo:

\section{5) «El escudo de la fe»}

Así designó, en efecto, Pablo - entre «las armas de Dios» (Ef 6, 11-18)a «la fe» cristiana: «El escudo» o la coraza del cristiano, en su cotidiana lucha contra «el maligno» (Ef 6,16), es decir, contra el diabólico «león rugiente» (cf. 1Pe 5,8-9), cuya victoria está condicionada precisamente por su fidelidad al Credo. Pues éste es, en efecto, «una gran defensa contra... la tentación del adversario» ${ }^{24} \mathrm{y}$, también, «nuestra coraza contra la adversidad» ${ }^{25}$ o nuestro protector «escudo contra el maligno» ${ }^{26}$, siendo por ello aquella Confesión de

23. Cf. a este respecto: E. Jammers, Credo: RGG, I 1880; J.A. Jungmann, El Sacrificio de la Misa, Madrid 21953, 509-23: 516ss; L. Lunz, Credo: LThK, III 88s; A Stenzel, Glaubensbekenntnis, II. Liturgisch: Ib., IV 938:39: 939. 24. San Ambrosio, o.c., 1; Cf. Id., De virginibus, III 5,20. 25. San Agustín, Serm. 58,13. 26. Sacrament. Gelasiano, 35 (PL 74, 1091). Así lo entendió ya san Agustín, comentando el Símbolo en su obra Sobre el combate cristiano (XII 13-XXXIII 34), tras la inicial exhortación a «luchar» victoriosamente «contra los dominadores de este mundo» (Ef 6,12) o «el diablo» (I 1-III 3). 
la $\mathrm{Fe}$ cristiana «la característica y señal» de «los genuinos soldados de Cristo" ${ }^{27}$ : así valoran al Símbolo algunos de sus más ilustres comentaristas antiguos, precisando que aquél es asimismo «un remedio contra el veneno de la serpiente» diabólica ${ }^{28}$, recibido por «los fieles para saber cómo deben prepararse a la lucha personal contra el diablo" ${ }^{29}$, a quien deben vencer resistiéndole «firmes en la fe» $(1 \mathrm{Pe} 5,9 \mathrm{a})$, que solemnemente profesaron «ante muchos testigos» (1Tim 6,12). Por eso el Credo se entrega y explica a los catecúmenos, como su «viático durante todo el tiempo de la vida» ${ }^{30}:$;No se puede caminar sin el Símbolo! De ahí la exhortación a que «lo reciten diariamente, al levantarse y al acostarse» ${ }^{31}$, protegiéndose con su «Símbolo antes de dormir y de comenzar la jornada» ${ }^{32}$, de modo que «lo que habéis aprendido y recitado, tenéis que guardarlo siempre en el Corazón y en el alma: Rumiándolo en el lecho y meditándolo por las plazas públicas, no olvidándolo al comer y sí soñando con él» ${ }^{33}$. Esta cálida exhortación sintetiza, sin duda, otro antiguo comentarista para sus catecúmenos, cuando los amonesta: ";Que nadie se olvide del Símbolo!» ${ }^{34}$. Es, en efecto, un precioso tesoro, conservado en el cofre de la Iglesia desde sus orígenes apostólicos. Pues a éstos se remonta:

\section{La antigüedad del Símbolo}

La investigación sobre el Símbolo tiene ya una secular y rica historia ${ }^{1}$. Desde finales de la pasada centuria hasta el presente, en efecto, renombrados especialistas - exégetas y patrólogos, historiadores y teólogos- han consagrado sendos y detenidos análisis a estudiar la génesis y formación de la Confesión de $\mathrm{Fe}^{2}$ cristiana o «Símbolo de los apóstoles». Así fue aquélla designa-

27. Catecismo Romano, I 3. 28. San Quodvultdeus, Serm. I de Symbolo, I 9; Cf. Serm. II, I 4; Serm. III, I 4. 29. San Ildefonso T., o.c., 33. 30. San Cirilo J., Cat. V 12. 31. San Agustín, Serm. 58,13. 32. Id., Serm. ad catech. de Symbolo, $1 . \quad 33$. Id., Serm. 215,1. 34. San Pedro Cris., Serm. 62 (PL 52, 372C).

1. Cf. a este respecto: D. G. Monrad, Die erste Kontroverse über den Ursprung des Apostolischen Glaubensbekenntnisses, Gotha 1881; S. Bäumer, Das Apostolische Glaubensbekenntnis. Seine Geschichte und sein Inhalt, Mainz 1893, $37-39$ (bibliogr.); C. Blume, Das Apostolische Glaubensbekenntnis, Freiburg 1893, 66-210; Th. Zahn, Das Apostolische Symbolum, ErlangenLeipzig 1893, 4-48; F: Kattenbusch, Das Apostolische Symbol, I, Leipzig 1894, 1-37; W. Sanday, Recent research on the history of the Creed: JThS 1 (1899) 3-22; 3 (1902) 1-21; J. Lebreton, Chronique d'histoire des origines chrétiennes, en: RSR 13 (1923) 349-53; J. de Ghellinck, L'histoire du Symbole des Apôtres: RSR 18 (1928) 118-25; Id., Patristique et Moyen Age. Les recherches sur les origines du Symbole des Apôtres, Bruxelles-Paris 1946; P. Feine, Die Gestalt des Apostolischen Glaubensbekenntnis in der Zeit des Neuen Testaments, Leipzig 1925, 5-40; F.J. Badcock, The history of the Creeds, London 21938; B. Lohse, Bekenntnis. IV. Theologiegeschichtlich: RGG, I 993s; H. Laur, Bekenntnisbildung: Ib., 1009-11; J. Quasten, Symbolforschung: LThK, IX 121012; R. Murray, Recent studies in early Symbolic Theology: HeyJ 6 (1965) 412-33. 2. Cf. A. Harvey, The history and theology of the three Creeds, London 1852; M. Nicolás, Le Symbole des 
da, efectivamente, desde mediados del s. IV ${ }^{3}$. No sin motivo. Pues aquel nombre traduce la convicción del origen apostólico del Credo. Es lo que atestigua expresamente una tradición antigua, reproducida en los albores del s. v por un comentarista del Símbolo: antes de dispersarse por el mundo, los apóstoles decidieron establecer «una norma común para su futura predicación» $\mathrm{y}$, «llenos del Espíritu Santo», redactaron «el breve compendio de» aquélla, «aportando cada uno lo que pensaba» y considerando como «norma doctrinal para los creyentes» ese compendio que, «por muchas y justificadas razones, denominaron Símbolo» ${ }^{4}$. Esta tradición vetusta, luego legendariamente ampliada ${ }^{5}$, fue aceptada como histórica durante el período patrístico y medieval, hasta que, a principios del concilio de Florencia (a. 1438), el representante de los griegos -Marcus Eugenios- aseguró ignorar tal «Credo apostólico»: ¡un duro golpe de piqueta, asestado con ello a la mencionada y venerable tradición multisecular! No el único. Pues el origen apostólico del Símbolo fue negado desde entonces - más o menos radicalmente- por varios autores ${ }^{6}$, siendo actualmente unánime la valoración crítica de aquella tradición como una piadosa leyenda. ¡No desprovista, sin embargo, de un sólido fundamento histórico! Así lo reflejan:

Apôtres. Essai historique, Paris 1867; R. Lumby, The history of the Creed, Cambridge-London 1873; A. Swainson, The Nicene and Apostles' Creed..., London 1875; A. Harnack, a.c. («Apostolisches Symbol»), 744-52; Id., Das Apostolische Glaubensbekenntnis, Berlin 1892; Th. Zahn, Das Apostolische Symbol, Erlangen-Leipzig 1893; S. Bäumer, Das Apostolische Glaubensbekenntnis. Seine Geschichte und sein Inhalt. Mainz 1893; H.B. Swete, The Apostles' Creed: Its relation to primitive Christianity, London 1894; F. Kattenbusch, o.c., II, Leipzig 1900, 3-347; A.C. McGiffert, The Apostle's Creed. Its origin, its purpose and its historical interpretation, New York 1902; A. Vacant, Apôtres (Symbole des): DYhC I 1673-79: 1673-76; A. Westphal, Le Symbole des Apôtres. Sa formation, le valeur réligieuse de son enseignement, Neuilly 1928, 48-101; H. Lebreton, Le Symbole baptismal, en: «Histoire du dogme de la Trinité», II, Paris 1928, 141-173; Id., Les origines du Symbole baptismal: RSR 20 (1930) 97-124; J. Ruiz Goyo, Los Orígenes del Símbolo apostólico: EstEcl 13 (1934) 316-37; Th. Camelot, Le Symbole des Apôtres. Origines, developpment, signification: LumVie 2 (1952) 29-80; Id., Símbolo de la fe: SM, V (Barcelona 1976) 359-366; H. Leclercq, Symbole: DACL, XV 1756-78 (bibliogr.); J.D.N. Kelly, Apostolisches Glaubensbekenntnis: LThK, I 760-62 (bibliogr.); A. Adam, Apostolikum. I. Entstehung: RGG, I 510-13; P. Franzen, Glaubensbekenntnis. I. Geschichte und theologische Bedeutung: LThK, IV 935-38; C. Eichenseer, o.c., 75-107; H. Lietzmann, Zur Geschichte des Symbols: «Kleine Schriften», III (TU 74), Berlin 1962, 161-281: 163-248; J. Quasten, Patrología, I, Madrid 21968, 32-38 (bibliogr.); H. de Lubac, o.c., 19-53; J.N.D. Kelly, o.c., 1-99 (trad. españ., 15-124). Más bibliografía, infra, n. 99. 3. Cf. San Ambrosio, Ep. 42,5; Explan. Symb., 2.3.7; Const. Apost., VI 14; San Jerónimo, Contr. Juan Jer., 28; Juan Casiano, De incarn. Christi, VI 3.4; etc. El Símbolo es, pues, «la regla apostólica»: San Ildefonso, De cogn.bapt., 32. 4. Rufino A., o.c., 2; Cf. también San Ildefonso, T. De cogn.bapt., 32. 5. Hacia el s. VIII se atribuyó a cada uno de los doce apóstoles la redacción de uno de los doce artículos del Credo: Cf. Seudo-Agustín, Serm. 240 (PL 39, 2189), reproducido por J.N.D. Kelly, o.c., 3 (trad. españ., 17). A este respecto, Cf.: S. Bäumer, o.c., 24-25; C. Blume, o.c., 200-205; F. Kattenbusch, o.c., II 3-24; A. Vacant, a.c., 1676-79; C. Eichenseer, o.c., 49-53; J.N.D. Kelly, o.c., 1-4 (trad. españ., 15-18). 6. Cf. D.G. Morad, Die erste Kontroverse über den Ursprung des Apostolischen Glaubensbekenntnisses, 


\section{Las raíces neotestamentarias del Símbolo}

El Credo no es obra de la Iglesia: no es producto de su litúrgia, ni elaboración de su catequesis, ni resultado de su reflexión teológica. El testimonio litúrgico, catequético y teológico del mismo hunde sus raíces, más bien, en el subsuelo de la revelación neotestamentaria ${ }^{7}$, a este respecto anticipada y preparada en alguna medida tanto por los credos veterotestamentarios como $-\mathrm{y}$ sobre todo- por las confesiones judaicas. En efecto:

1) Ya Israel expresó su fe ${ }^{8}$ en credos históricos ${ }^{9} \mathrm{e} \mathrm{hímnicos}{ }^{10}$, confesando ${ }^{11}$ «entre las naciones» y «ante todas las gentes» ${ }^{12}$ al Dios que, además de crear «el cielo y la tierra» ${ }^{13}$, libró a su Pueblo de Egipto y lo condujo a la

Gotha 1881; W. Bornemann, Der Streit um das Apostolicum, Magdeburn 1893; Th. Zahn, Der Kampf um das Apostolikum, Nürnberg 1893; J. de Ghellinck, o.c., 18-220; J.N.D. Kelly, o.c., 4-6 (trad. españ., 19-21); V.H. Neufeld, o.c., 2-6. 7. A este respecto, además de la monografía de H.B. Swete (supra, n. 2), Cf. S. Bäumer, o.c., 158-75; C. Clemen, Die Anfänge eines Symbols im Neuen Testament: NKZ 6 (1895) 323-36; P.B. Whitfoord, The presence of an Creed in the New Testament: The Thinker 8 (1895) 416-22; A.E. Burn, An introduction to the Creeds and to the Te Deum, London 1899, 8-26; F. Kattenbusch, o.c., II, 335-47; A. Seeberg, Der Katechismus der Urchristenheit, Leipzig 1903, 45-210; J. Kunze, Das Apostolisches Glaubensbekenntnis und das Neue Testament, Berlin 1911, 37-70; P. Feine, o.c., 41-59.89-139; C. Fabricius, Urbekenntnis der Christenheit: «Fs. R. Seeberg», I, Leipzig 1929, 21-41; C.H. Moehlmann, The origins of the Apostles' Creed: JR 13 (1933) 301-19; E. Stauffer, Theologie des Neuen Testaments, Stuttgart 1945, 212-31; M; Meinertz, Das Palästinabuch, Köln 1946, 22-37 (=el Símbolo apostólico y el NT); Id., Teología del Nuevo Testamento, Madrid 21966, 631-41; P. Benoit, Les origines du Symbole des Apôtres dans le Nouveau Testament: LumVie 2 (1952) 39-60:50-58; H. Lietzmann, Die Anfänge des Glaubensbekenntnis: «Kleine Schriften», III 163-81; Id., Die Urform des Glaubensbekenntnis: Ib., 182-88; V.H. Neufeld, o.c., 42ss; O. Cullmann, Las primeras confesiones de fe cristiana: «La fe y el culto en la Iglesia primitiva», Madrid 1971, 63-122; H. Schlier, Die Anfänge des christologischen Credo: «Zur Frühgeschichte der Christologie» (QD 51), Freiburg 1970, 1358. 8. Cf. O. Procksch, Das Bekenntnis im AT, Leipzig 1936; Ch. Charlier, La profession de foi dans l'AT: LumVie 2 (1952) 16-38: 16-25.30-38; C. Westermann, Bekenntnis. II. Im AT und Judentum: RGG, I 989-91: 989s; R. Schnackenburg, Bekenntnis, II. Biblisch: LThK, II 143-44:143; G. von RAD, Teología del Antiguo Testamento, I, Salamanca 1972, 167-70.187s; Id., Estudios sobre el Antiguo Testamento, Salamanca 1976, 13-17; L. Rost, Das kleine Credo und andere Studien zum Alten Testament, Heidelberg 1965; J. Schreiner, Die Entwicklung des israelitischen «Credo»: Conc 2 (1966) 757-62; W. Richter, Beobachtungen zur theologischen Systembildung in der alttestamentlichen Literatur anhand des «kleinen geschichtlichen Credo»: Wahrheit und Verkündigung» (Fs. M. Schmaus), München 1967, 175-212; E. Zenger, Funktion und Sinn der ältesten Herausführungsformel: Ztschr. d.d.t. morgenl. Ges., Suppl. 1 (1969) 334342; J.I. Durham, Credo, Ancient Israelite: IDB Supl. vol. (1976) 197-99; G. Wallis, Die geschichtliche Erfahrung und das Bekenntnis zu Jahwe im Alten Testament: ThLZ 101 (1976) 801816; B. Lang, Confesiones de la fe de la Sagrada Escritura: Conc 138 (1978) 13-23:13-18. 9. Cf. Dt 6,20-24; 26,5-9; Jos 24,2-13. 10. Cf. Sal 78.105.136: ;confesiones hímnicas de Israel! 11. Así lo subrayan los LXX, con el reiterado uso del verbo exhomologeîn: Gén 29,35; 2 Sam 22,50; 1 Re 8,33.35 etc.; Is 45,24 etc; Tob 11,17; 13,3.6-8.10.16; Sal 6,5; 7,17; 9,1; 17,49 etc; Eclo 39,7.15; 51,1.2.12; Dan 6,10 etc; $2 \mathrm{Mac} 7,37 ; 8,27$; Cf. a este respecto, O. Michel, Homologéo: ThWNT, V 203-5. 12. Sal 17,49 (LXX); Tob 13,3 (LXX). 13. Gén 1,1; Cf. Sal 136,4-9. 
tierra prometida ${ }^{14}$. Una fe en el Dios de la creación y de la historia salvífica, condensada en el «Shemá» (Dt 6,4-5) o confesión de fe ${ }^{15}$ en la unicidad de Dios y su exigencia de amor total, que hizo de Israel el Pueblo de la confesión.

2) Eso se consideró también el judaísmo antiguo, cuyas reiteradas confesiones de $\mathrm{fe}^{16}$ se concentran asimismo en el «Shemá», unánimemente considerado como la característica confesión de fe en el único Dios y en su sólo señorío ${ }^{17}$.

3) Jesús condividió, sin duda, esa confesión de fe judaica en el único Dios y en su exigencia de amor total ${ }^{18}$, no sin subrayar que «el Señor del cielo y de la tierra» es «el Padre» (Mt 11,25par) suyo y de sus discípulos ${ }^{19}$, quienes como tal lo invocan en su Oración característica ${ }^{20}$. No fue ésa, sin embargo, la única confesión de los Doce. Pues tras haberles sido revelada gradualmente por el Maestro su dignidad mesiánica, ellos la confesaron por boca de Pedro con la profesión de fe - «Tú eres el Mesías» (Mc 8,29par) — más antigua del cristianismo ${ }^{21}$.

4) Reasumida y completada luego en las confesiones de fe propias de las primeras Comunidades cristianas ${ }^{22}$.

14. Cf. Dt 6,23-24; 26,8-9. 15. Subrayado por: G. von Rad, Deuteronomium (ATD) 8), Göttingen 1964, 45s; Id., Teología AT, I 290; E. Quell, ThWNT, III 1079s; Ch. Larcher, art. cit., 20; Cf.: N. Lohfink, Höre Israel, Düsseldorf 1965, 63ss; S.D. Bridge, The Yoke of the Kingdom. An exposition of Dt 6, 4-5: Interpr 27 (1973) 273-306. 16. Cf.: Ch. Larcher, a.c., 25-30; C. Westermann, a.c., 990s; O. Michel, a.c., 205s; V.N. Neufeld, o.c., 34-41. 17. Así se expresan todos los autores: J.D. Eisenstein, Shemá: JewEnc, XI 266s; W. Bousset-H. Gressmann, Die Religion des Judentums, Tübingen 1925, 190; STR.- BILL., IV 189s; Id., II 28-30; J.-M. Lagrange, Le Judaïsme avant Jésus-Christ, Paris ${ }^{3} 1931$, 464s; I. Elbogen, Der jüdische Gottesdienst, Frankfurt 1931, 24s; A. Vincent, Le Judaïsme, Paris 1932, 79; Ch. Larcher, a.c., 26s; V.H. Neufeld, o.c., 35; Ch. Ben Chorim, Betendes Judentum, Tübingen 1980, 48; S. Sabugal, Abbá..., 344s (bibliogr.). 18. Mc 12,28-29par (Cf. J. Jeremias, Neutestamentliche Theologie, Gütersloh 1971, 128: trad. españ., Salamanca 1974, 220s). Por lo demás, en el contexto de Su mensaje central sobre el Reinado de Dios enseñó Jesús asimismo, que no se puede «servir a Dios y al dinero» (Mt $6,24=\mathrm{Lc} 16,13)$, sin duda por ser aquél «el único Dios verdadero» (Jn 17,3). Parece, pues, claro que «la confesión del único Dios verdadero es uno de los elementos centrales del mensaje de Jesús»: K. Rahner, Theos en el Nuevo Testamento, en: «Escritos de Teología», I, Madrid 1961, 93167: 117. 19. Cf. J. Jeremias, $A b b a$, Göttingen 1966, 33-37 (trad. españ., 37-73); Id., o.c., $67-$ 73 (trad. españ., 211-18); S. Sabugal, Abbá..., 345. 20. Cf. J. Jeremias, Theologie NT, 191s (trad. españ., 231s); S. Sabugal, El Padrenuestro, 107-118; Id., Abbá..., 397-421. 21. Cf. S. Sabugal, Christós, Barcelona 1972, 85-94: 92s; V. H. Neufeld, o.c., 108-126.142s. 22. Además de la bibliografía citada (supra, n. 7), Cf.: O. Michel, Homologéo: TWNT, V 206-217; E. Kamlah, Bekenntnis. III. Im NT: RGG, I 991-93 (bibliogr.); Ch. H. Dodd, The apostolic preaching and its developpment, London 1936; E. Zeller, Bekenntnis, III: LThK, II 145-46; H.F. Campenhausen, Das Bekenntnis im Neuen Testament: ZNW 63 (1972) 210-253; K. Wengst, Christologische Formeln und Lieder des Urchristentums (StNT, 7), Gütersloh 1972; B. Lang, Confesiones de fe en la Sagrada Escritura: Conc 138 (1978) 13-23: 19ss; X. Pikaza, Las confesiones de fe en la Biblia. Sus formas y significado, en: Com 2 (1979) 7-19; D. Fürst, Confesar la fe: DTNT I 292-95: 294s. 
a) Quienes, en efecto, según el preanuncio del Señor resucitado recibieron «la promesa del Padre» y fueron «bautizados con el Espíritu Santo» (Act 1,4-5.7-8) el día de Pentecostés (Act 2,1-4), anunciaron seguidamente al pueblo ${ }^{23}$ y a los paganos ${ }^{24}$ el cumplimiento de las Escrituras mesiánicas en la pasión y muerte de Jesús de Nazaret así como la Buena Nueva de su resurrección por «el Dios ${ }^{25}$, que hizo el mundo y cuanto hay en él» (Act 17,24.31), quien lo exaltó a su derecha y le dio la potestad de infundir el Espíritu Santo (Act 2,33), constituyéndolo «Señor y Mesías» (Act 2,36), el Portador de la bendición (Act 3,26 ) y el único Salvador (Act 4,12$)$, el «Juez de vivos y muertos» (Act 10,42; cf. 17,31); Él es, pues, el Mesías ${ }^{26}$ y el mesiánico Hijo de Dios ${ }^{27}$, por quien se concede «el perdón de los pecados» ${ }^{28}$ a quienes, convirtiéndose y creyendo en Él ${ }^{29}$, se bautizan en su nombre (Act 2,38). Y los que se bautizaban «en el nombre del Señor Jesús» ${ }^{30}$ y recibían el Espíritu Santo ${ }^{31}$ formaban «la comunidad» (Act 2,$47 ; 15,30$ ) de los creyentes aunados en «un solo corazón y un alma sola» ${ }^{32}$, es decir, «la Iglesia» de los judíos ${ }^{33}$ y paganos ${ }^{34}$. Aquélla nació, pues, por la fe en «la Palabra de Dios» $(1 \mathrm{Pe} 1,23)$ y el bautismo (Tit 3,5; Jn 3,5-6).

b) Pero los que creyeron «en su corazón, ...para conseguir la justicia», deben asimismo «confesar» esa fe «con la boca, para obtener la salvación» ( $R m$ 10,9-10). De ahí que la fe interior de los creyentes se traduce necesariamente en la confesión exterior ${ }^{35}$, solemnemente realizada ya por ellos durante el bautismo (cf. 1Tim 6,12-13) y en la que deben «mantenerse firmes» (Hebr $4,14 ; 10,23)$.

c) ¿Qué contenido envuelve esa confesión o profesión de fe?:

-Ciertamente la existencia de «un solo Dios ${ }^{36}$ y Padre de todos» ${ }^{37}$, por ser «el Padre de nuestro Señor Jesucristo» ${ }^{38} \mathrm{y}$ «Padre nuestro» ${ }^{39}$, siendo asimismo «el Señor todopoderoso» ${ }^{40}$, a quien «nada es imposible» y «todo lo puede» ${ }^{41}$, por ser «el Creador» ${ }^{42}$ de cuanto existe ${ }^{43}$ y, por tanto, del hombre ${ }^{44}$.

-Pero aquella confesión afirma sobre todo que «Jesús es el Señor» ${ }^{45}$, el

23. Act $2,22-36 ; 3,12-26 ; 4,8-12 ; 9,20-22 ; 13,16-41 ; 17,1-3$ etc. 24. Cf. Act 10,34-43; $17,22-31 ; 28,31$. 25. Cf. Act $2,23-32 ; 3,13-15 ; 4,10 ; 10,39-42 ; 13,27-37 ; 17,3.18 .21$; 26,8. 26. Act 9,$22 ; 17,3 ; 18,5$; Cf. $3,13.18$ 27. Act 9,20 ; Cf. 13,33 . 28. Act 13,38 ; Cf.10,43; 26,18. 29. Act 3,$19 ; 13,39 ;$ Cf. 14,$16 ; 26,18.20$. 30. Act 8,$16 ; 10,48 ; 19,5$; 22,16 . 31. Cf. Act 2,$38 ; 8,15-17 ; 10,44-47 ; 19,6$ 32. Act $4,32-35 ; 2,42-47$. 33. Act $8,1.3$; 9,$31 ; 11,22.26 ; 12,1.5$ etc. 34. Act 13,$1 ; 14,23 ; 15,41 ; 16,5$. 35. Cf. Fil 2,$11 ; 1$ Tim $6,12-13$; Hebr 3,1; 4,14; 10,23; Mt 10,32; Lc 12,8; Jn 9,22; 12,42; 1Jn 2,23; 4,2-3.15; 2 Jn 7 . 36. Gál 3,20; 1 Cor 8,4; Rm 3,30; Ef 4,6; 1 Tim 2,5; Sant 2,19. 37. Ef 4,6; 1 Cor 8,6a. 38. 2Cor 1,3; 11,31; Rm 15,16; Ef 1,3; Col 1,3. 39. 1Tes 3,11.13; 2Tes 1,1; 2,16; Gál 1,3.4; 1Cor 1,3; 2 Cor 1,2; Ef 1,2; 4,20; Flm 3; Cf. Gál 4,6; Rm 8,15. 40. 2Cor 6,18; Cf. Apoc 1,8; 4,8; 11,17; 15,3; $16,7.14 ; 19,6.15 ; 21,22$. 41. Lc 1,37; Mc 10,27par. 42. Rm 1,25; 1Pe 4,19; Mt 19,4; Cf. Rm. 1,20. 43. Cf. Ef 3,9; Col 1,16; 1 Tim 4,3; Apoc 4,11; 10,6. 44. Cf. 1Cor 11,9; Col 3,10; Mt 19,4= Mc 10,6. 45. Rm 10,9a; Fil 2,11; Cf. 1Cor 8,6b; Ef 4,5. 
Mesías ${ }^{46}$ y el Hijo de Dios ${ }^{47}$, por Él «enviado al llegar la plenitud de los tiempos» y «nacido de mujer» ${ }^{48}$ - 0 «del linaje de David según la carne» ${ }^{49}$ - por obra del Espíritu Santo ${ }^{50}$; Él «murió y resucitó» ${ }^{51}$, pues «fue crucificado» ${ }^{52}$ $\mathrm{y}$ «murió por nuestros pecados» y «por nosotros» ${ }^{53}$, bajo Poncio Pilato ${ }^{54}$, «y fue sepultado» ${ }^{55}$; pero «Dios lo resucitó de entre los muertos» ${ }^{56} \mathrm{y}$ «lo elevó al cielo» ${ }^{57}$, donde «está sentado a la derecha de Dios» ${ }^{58}$ y de donde «ha de venir a juzgar a vivos y a muertos» ${ }^{59}$, - «itodos hemos de comparecer ante el tribunal de Cristo?» ${ }^{60}$-, tras haber resucitado aquéllos ${ }^{61}$.

—Como no existe más que «un solo Dios Padre» y «un solo Señor» ${ }^{62}$; también hay «un solo Espíritu» ${ }^{63}$, es decir, «el Espíritu Santo» ${ }^{64}$, el cual, por «proceder del Padre» y ser enviado por el Hijo «de junto al Padre» ${ }^{65}$, es «el Espíritu de Dios» ${ }^{66}$ y «el Espíritu de Cristo» ${ }^{67}$, que habló por los profetas ${ }^{68}$; también es «el Espíritu vivificante» (Jn 6,63), en cuanto autor de la regeneración bautismal ${ }^{69}$ y filiación divina ${ }^{70}$ de los fieles, en quienes habita ${ }^{71}$, vivificando y santificando también - mediante sus dones- a la Iglesia ${ }^{72}$, en cuyo Cuerpo mora (1Cor 3,16-17). Pueś como existe «un solo Espíritu», también hay «un solo Cuerpo» ${ }^{73}$, es decir, «el Cuerpo de Cristo» ${ }^{74} \mathrm{o}$ «la Iglesia» ${ }^{75}$, de la que éste es su "Cabeza suprema» ${ }^{76}$; aquélla es, pues, una ${ }^{77} \mathrm{y}$ además santa $^{78}$, pues Cristo la «amó y se entregó para santificarla... y presentarla

46. Cf. Mt 16,16par; Jn 9,22; 11,27; 20,31; 1Jn 2,22; 4,2; 5,1. 47. Cf. Rm 1,3-4; Hebr 4,14; Lc 4,41; Mt 14,33; 16,16; 27,54par; Jn 1,49; 11,27; 20,31; 1Jn 4,15; 5,5. 48. Gál 4,4; Cf. Mt 1,25-2,1; Lc 2,1-7. 49. Rm 1,3; Cf. 2Tim 2,8; Mt 1,1.6-16; Lc 3,23-31. 50. Cf. Mt 1,1825; Lc 1,26-38. 51. 1 Tes 4,$14 ; \operatorname{Rm} 4,25 ; 8,34 ; 14,9 ; 1$ Pe 3,18 etc. 52. 2Cor 13,14; Act 2,36; 4,10; 1Cor 2,8; Cf. Mt 27,33-44par; Jn 19,16-22; Gál 3,13. 53. 1Tes 5,10; Gál 1,4; 2,20; 1Cor 15,3 ; 2Cor 5,14; Rm 4,25; 5,6-8; 1 Tim 2,6; Tit 2,14; $1 \mathrm{Pe} 2,21-22 ; 3,18$; Cf. Mt 20,28par. 54. Cf. Act 3,13-14; 4,27-28; 13,28; 1Tim 6,13; Mt 27,15-56par; Jn 18,28-19,37. 55. 1Cor 15,4a; Cf. Rm 6,4; Mt 27,57-61 par; Jn 20,38-42. Complemento de la fe en la sepultura o verdadera muerte de Jesús es la fe en su «descenso a los infiernos» o ida a «los muertos» (1Pe 3,18-20; 4,6; Cf. Act 2,27.31; Ef 4,9), expresión de la «predicación» o "anuncio» (1Pe 3,$19 ; 4,6)$ cristiano tanto de la ilimitada eficacia salvífica de su muerte expiatoria (Cf. $1 \mathrm{Pe}$ $3,18)$, - jincluso «los muertos» pueden participar de ella! - , como de Su total victoria sobre la muerte (Cf. Apoc 1,18; Mt 27,52; 2 Tim 1,10). 56. 1Tes 1,10; 1Cor 6,14; 15,4b.15; 2Cor 4,14; Gál 1,1; Rm 4,24; 6,4; 10,9; Col 2,12; Ef 1,20;1Pe 1,21. 57. Lc 24,51; Act 1,2. 9-11; Mc 16,19; Cf. Ef 4,8-10. 58. Rm 8,34; Ef 1,20; Hebr 1,3-13; 8,1;10,12; 12,2; 1Pe 3,22; Mc 16,19b; Cf. Mt 22,44par; 26,64par; Act 7,55 etc. 59. 2Tim 4,1; 1Pe 4,5; Cf. Rm 2,12-16; Act 17,31; Mt 13,40-43.48-50; 25,31-46; Jn 5,27; 12,48; Apoc 11,18; 20,12-13. 60. 2Cor 5,10; Cf. $\operatorname{Rm} 14,10$. 61. 1 Tes 4,$16 ; 1$ Cor 6,$14 ; 15,12-53 ; 2$ Cor 1,9; 2,14; Rm 8,11; Apoc 20,3; Cf. Mt 22,23-32par; Jn 11,24. 62. 1Cor 8,6; Ef 4,5-6. 63. Ef 4,4. 64. 1Tes 1,5.6; 4,8; 1 Cor 6,19; Rm 5,5; 9,1; 14,17 etc; $1 \mathrm{Pe} 1,12 ; 2 \mathrm{Pe} \mathrm{1,21;} \mathrm{Jds} 20$. 65. Jn 15,26; Cf. 7,39; Act 2,33; 1 Cor 2,12. 66. 1 Cor $2,11.14 ; 3,16 ; 7,40 ; 2$ Cor 3,3 etc; Rm 8,9; 1 Jn 4,2. 67. Rm 8,9; Cf. Gál 4,6; 2 Cor 3,17 . 68. Cf. 2 Pe 1,20-21; 1Pe 1,10-12; 2Tim 3,16; Mc 12,36par. 69. Cf. Jn 3,5-6; 1 Cor 6,11; 12,13; Ef 1,13; 4,30; Tit 3,5-6. 70. Cf Gál 4,6; Rm 8,14-17. 71. 1Cor 6,19; Cf. 2 Cor 1,$22 ; 5,5 ; \operatorname{Rm} 5,5 ; 2 \operatorname{Tim} 1,14$. 72. $2 \mathrm{Tes} 2,13$; 1 Cor 6,$11 ; 1 \mathrm{Pe} 1,2$; 1 Cor 12,4-11. 73. Ef 4,4; 1 Cor 12,13; Rm 12,5; Ef 2,16; 3,6; Col 3,15. 74. 1Cor 12,27; Ef 4,12.16; 5,30. 75. Ef 1,$23 ; 5,23 ;$ Col 1,18.24. 76. Ef 1,23; Cf 5,23; Col 1,18; 2,19. 77. Cf 1 Cor $1,11-13 ; 10,16-17 ; 12,4-27$; Rm 12,4-8; Ef 4,3-6; Col 1,15. 
santa e inmaculada» ${ }^{79}$; también es católica o universal ${ }^{80}$, en cuanto enviada por su divino Fundador «a todas las gentes» ${ }^{81}$, para llamar «a todos» los hombres al banquete del Reino ${ }^{82}$ y ser tanto «la sal de la tierra» como «la luz del mundo» ${ }^{83}$; es finalmente apostólica la Iglesia ${ }^{84}$, que reconoce «un solo bautismo» (Ef 4,5), conferido «en el nombre del Señor Jesús» ${ }^{85}$ o «en Cristo» ${ }^{86}$ y «en el Espíritu Santo» ${ }^{187}$, «en el nombre del Señor Jesucristo y en el Espíritu de nuestro Dios» (1Cor 6,11), es decir, «en el nombre del Padre y del Hijo y del Espíritu Santo» (Mt 28,19); es el bautismo requerido para obtener el perdón de los pecados ${ }^{88} \mathrm{y}$ necesario para la salvación ${ }^{89}$ de quienes esperan conseguir el don divino de la . Vida eterna ${ }^{90}$.

d) Todas estas verdades, centradas en torno a la confesión trinitaria, constituyen el objeto de «la buena», y «sana enseñanza» ${ }^{91}$ apostólica o «las palabras sanas», a las «que hay que atenerse» como «norma» ${ }^{92}$ de la fe, por ser «el depósito» ${ }^{93}$, que se debe conservar «con la ayuda del Espíritu Santo» (2Tim 1,14), ya que en él se contienen «las palabras de la fe» (1Tim 4,6) o «el misterio de la fe», que se debe «guardar con una conciencia pura» (1Tim 3,9), por ser el compendio de «una sola fe» $(\mathrm{Ef} 4,5)$ o «la fe» ${ }^{94}$, que se debe «conservar sana» ${ }^{95}$. Ahora bien, todas estas expresiones son del todo afines a las designaciones del Símbolo por los Padres de la Iglesia, calificándole de «breviario de la fe» o su «cifra» y «sucinta fórmula», la «breve pero grande norma de la fe» o simplemente «la fe» $y$, más exactamente, «la fe santa y apostólica»» ${ }^{96}$.

La vetusta leyenda sobre la composición del Símbolo por los Apóstoles ${ }^{97}$ tiene, pues, un sólido fundamento histórico: Aunque no haya sido redactado por los Doce, sí compendia «el depósito» de «la fe»o «la enseñanza» trasmitida por los Apóstoles y confesada por la Iglesia ${ }^{98}$ o comunidad de los creyen-

78. Cf 1 Cor 1,$2 ; 3,17 ; 5,1-8 ; 6,1-2.11$ etc; 2 Cor 1,$1 ; 8,4$ etc; Rm 1,$7 ; 8,27$ etc; 1 Tes $4,3-7$; Ef 1,1.4.15; 2,21 etc; Fil 1,1; 4,21; Col 1,2; 3,12 etc; Hebr 3,1; 6,10; 13,24; 1Pe 1,15-16; 2,9; Apoc 22,11. 79. Ef 5,26-27; Cf. Col 1,22; Hebr 13,12. 80. Cf. Rm 1,8; 10,18; Col 1,6; Mt $13,43=$ Lc 13,20s. . 81. Mt 28,19; Cf. Mc 16,15. Lc 24,47; Act 1,8. 82. Mt 22,9-10=Lc 14,21-23. 83. Mt 5,13-16; Cf. Fil 2,15. 84. Cf. Rm 12,28 (=Ef 4,14); Ef 2,20; Apoc 21,14. 85. Act 2,$38 ; 8,16 ; 10,48 ; 19,5$. 86. Gál 3,27; Cf. Rm 6,3-4; Col 2,12. 87. 1Cor 12,13 ; Cf. Act 11,16 88. Act 2,38 ; Cf. 22,16 . 89. Cf. Mc 16,$16 ; 1 \mathrm{Pe} 3,21$. 90. Rm 6,2223; Cf. 2,$7 ; 5,17.21 ; 8,11 ; 1$ Cor 15,22; 2 Cor 5,4; Gál 6,8; Col 3,4; 1Tim 1,16;6,12; Tit 1,2; 3,7; $1 \mathrm{Jn} 2,25 ;$ Jds 21 etc. 91. $1 \mathrm{Tim} 4,6 ; 2 \mathrm{Tim} 4,3$; Tit 1,9. 92. $1 \mathrm{Tim}$ 6,3; $2 \mathrm{Tim}$ 1,13. 93. $1 \operatorname{Tim} 6,20 ; 2 \operatorname{Tim} 1,12.14$. 94. 1 Tim 1,$19 ; 4,1 ; 6,10.21 ; 2 \operatorname{Tim} 4,7$; Tit.1,13; Jds 3. 95. $1 \operatorname{Tim} 1,19 ; 2 \operatorname{Tim} 4,7$; Tit 1,13 . 96. Cf. supra, 4s. 97. Cf. supra, 11. 98. A esta conclusión llegan también: Th. Zahn, o.c., 37.46s; J. Kunze, o.c., 100; P. Feine, o.c., 79-83.144s; A. Seeberg, o.c., 271-73; E. Norden, Agnostos Theos, Leipzig 1913, 269-73: 273; M. Meinertz, Teología NT, 639; P. Benoit, a.c., 59s; H. Leclercq, art. Catéchèse, en: DACL, II 2544; Id., a.c., 1762s; E. Kamlah, a.c., 992; J.N.D. Kelly, a.c. (supra, n. 2), 760s; Id., o.c., (trad. españ.) 25.27.39.45; E. Schillebeeckx, Revelación y Teología, Salamanca 1968, 197-210: 203; H. de Lubac, o.c., 52; W. Pannenberg, La fe de los apóstoles, Salamanca 1975, 14; Th. Camelot, Símbolos de la fe, (supra, n. 2), 362. Esa conclusión condividen también, con respecto a la parte cristológica del Símbolo: H. Lietzmann, Die Anfänge..., 181; H. Schlier, a.c., 58. Está; pues, definitivamente superada la antigua - patrística y medieval - concepción sobre la composición del Cre- 
tes, que, «elegidos según el previo conocimiento de Dios Padre, -con la acción santificadora del Espíritu-, para obedecer a Jesucristo» $(1 \mathrm{Pe} \mathrm{1,2),} \mathrm{fue-}$ ron «lavados... en el nombre del Señor Jesucristo y en el Espíritu de nuestro Dios» (1Cor 6,11) o bautizados «en el nombre del Padre y del Hijo y del Espíritu Santo» (Mt 28,19). De esta neotestamentaria fórmula bautismal se hace reiterado y amplio eco:

\section{El testimonio post-apostólico}

1) Que el Símbolo de la Fe se formó a raíz de esta última fórmula bautismal (Mt 28,19), como desarrollo o ampliación catequética de la misma, es un hecho atestiguado ya por los primeros Padres de la Iglesia ${ }^{99}$. En efecto, la cristológica confesión monomembre o profesión de fe en la concepción virginal de Jesús, su crucifixión bajo Poncio Pilato y su resurrección es atestiguada por san IGNACIO Antioqueno ${ }^{100} \mathrm{y}$, más tarde, por san JUSTINO mártir, quien la completa con la fe en la Ascensión del Señor y su retorno como «Juez de todos» ${ }^{101}$. Asimismo, de la confesión bimembre o profesión de fe en Dios y en

do por los apóstoles, sostenida aún en la época moderna por un autor católico, según el cual sus indiscutibles raíces neotestamentarias muestran que el Símbolo apostólico «es en su forma original» no sólo «la reproducción más fiel de la doctrina apostólica» sino también «una obra de hombres apostólicos», es decir, «de los mismos apóstoles o de discípulos de los apóstoles», (S. Bäumer, o.c., 158-75: 175). Las raíces neotestamentarias del Credo (Cf. sufra), sin embargo, muestran que aquella leyenda «contiene más verdad y sabiduría que la afirmación de que el Símbolo es producto del siglo V o VI»: Th. Zahn, o.c., 48 (Lo cursivo es nuestro). 99. A este respecto, además de la bibliografía citada (supra, n. 2), Cf. en particular: C. Blume, o.c., 210-292; A.E. Burn, o.c., 33-44; F.Kattenbusch, o.c., II, 24-179.277-335.354-60; P. Battifol, Apôtres (Symbole des); DThC I 1660-73; 1670ss; J. Kunze, o.c., 19-37; A. Nussbaumer, Das Ursymbolum nach dem Epidexis des hl. Irenäus und dem Dialog Justins, Paderborn 1921; H. Lebreton, a.c., (RSR 1930), 122ss; Th. Camelot, a.c., (LumVie 1952), 63-71; H. Leclercq, a.c., (supra, n. 2), 1763-76; A. Adam, a.c., 511s; C. Eichenseer, o.c., 60-75.79-94; H. Lietzmann, Symbolstudien V-IX: «Kleine Schriften» III, 213-29; J.N.D. Kelly, a.c., 761; Id., o.c., 65-99 (trad. españ., 87-124). Los textos originales son reproducidos por A. Hahn-G.L. Hahn, Bibliothek der Symbole und Glaubensregeln der Alter Kirche. Berlin ${ }^{3} 1897$ (Hildesheim 1962), 1-13.35. La instrucción catequética previa al bautismo conferido «en el nombre del Padre y del Hijo y del Espíritu Santo» (Mt 28,19), atestiguada expresamente por el Didajista (Cf. Did 7,1), san Justino (Cf. 1.Apol. 61, 2-3) y san Hipólito R. (Cf. Trad. Apost., 17-18.21), así como la ausencia de polémica antidoceta y antignóstica en el contexto inmediato de las confesiones trinitarias y fórmulas bautismales de san Ignacio A. (Magn 13, 1-2), san Justino (Cf. infra, nn. 106.113), san Ireneo (Cf. infra, nn. 107.114) y Tertuliano (Cf. infra, nn. 109.115), muestra ya que el Símbolo se originó no directamente a raíz de la polémica antignóstica (contra: A.C. McGiffert, The Apostle's Creed, New York 1902, 62s; G. Krüger, Das Taufbekenntnis der römischen Gemeinde als Niederchlag des Kampfes geben Marcion: ZNW 6 [1905] 72-79:77ss), sino como normal desarrollo o ampliación catequética de la fórmula bautismal primitiva (Mt 28,19). Así con A. Harnack, Apostolisches Symbol: RE I, 741-55:756s; Cf. también: H. Lietzmann, Die Urform des Glaubensbekenntnis: o.c., 182-88:185; J.N.D. Kelly, o.c., 145s (trad. españ., 177s). 100. Esm. 1,1-2; Cf. también: Ef. 18,2; Trall. 9. 101. Cf. IApol. 21 ,1; 31,7; 42,4; 46,5; Diál. 63,1; 85,2; 132,1; Cf. 126,1. Así también Meliton S., Sobre la Pascua, 70.104. 
Jesucristo se hacen claro y reiterado tanto san IGNACIO ${ }^{102}$ como san POLICARPO ${ }^{103} \mathrm{y}$, luego, san IRENEO ${ }^{104}$. Más frecuente, sin embargo, es la confesión trinitaria: latente ya en algunos PADRES APOSTÓLICOS ${ }^{105}$, es atestiguada sobre todo por san JUSTINO ${ }^{106} \mathrm{y}$, más ampliamente, por san IRENEO ${ }^{107}$, quien ofrece una forma casi completa del Símbolo o «la fe» recibida por «la Iglesia... de los apóstoles y sus discípulos» ${ }^{108}$; esto mismo reproducen los textos de TERTULIANO sobre «la regla de fe» ${ }^{109}$, así como los de ORÍGENES sobre «las verdades claramente trasmitidas por la predicación apostólica» ${ }^{110} \mathrm{y}$ sobre «la fe completa» del cristiano ${ }^{111}$. Este reiterado testimonio de la confesión de $\mathrm{Fe}$, designado «Regla de la verdad» (San Ireneo) o «Regla de la fe» (Tertuliano) por sintetizar «la Fe completa» (Orígenes) de la Iglesia, no se identifica con el Símbolo: éste sintetiza la catequesis pre-bautismal y, en cuanto tal, no expresa toda la fe de los bautizados (de ahí que no se aluda en él p.e. a la eucaristía, enseñanza post-bautismal reservada a los neófitos), formulada en la «Regla de la verdad» o «de la fe», elaborada como desarrollo teológico del Símbolo bautismal " ${ }^{11}$ a a raíz, sin duda, de la bautismal fórmula trinitaria mateana (Mt 28,19). Reproducida ésta por el DIDAJISTA ${ }^{112}$ y luego ampliamente por san JUSTINO ${ }^{113}$, de ella se hace reiterado eco san IRENEO ${ }^{114}$, veladamente TERTULIANO ${ }^{115} \mathrm{y}$, de modo explícitamente más amplio, san HIPÓLITO Romano, según el cual al bautizando «le impone la mano» quien bautiza y le sumerje tres veces en el agua, tras haber respuesto aquél «creo» - antes de cada inmersión- a las tres preguntas:

102. Cf. Magn. 8,2. 103. Fil 2,1 104. Adv. Haer., III 1,$2 ; 4,2 ; 16,6$. 105. Cf.: San Clemente R., ICor 46,5; San Ignacio A., Magn. 13,1-2. A este respecto, Cf. infra, 53, n. 33 (bibliogr.). 106. Cf. 1Apol. 6,2; 13,1-3; 65,3;67,2; Cf. a este respecto infra, 53, n. 33 (bibliogr.). También Aristides, Apol. 15,1.2. 107. Cf. Exposición de la predicación Apostólica, 6; Adv. Haer., IV 33,7 («la regla de nuestra fe»): Textos en A. Hahn-G.L. Hahn, o.c., 6-8; J.N.D. Kelly, o.c., 77s (trad. españ., 100s); a este respecto, Cf. infra, 53, n. 34 (bibliogr.). 108. Cf. $A d v$. Haer., I, 10,1: J.N.D. Kelly, o.c., 79 (trad. españ., 102). 109. De praescr., 13,1-6; Adv. Prax., 2,1-2; Cf. también: De praescr., 36,4-6; De virg. vel., 1. A este respecto, Cf. infra, 53, n. 35 (bibliogr.). 110. De princ., I pref. 4-5.7-8. 111. In Ev. Ioan., 32,16. Los textos de Orígenes son reproducidos por A. Hahn-G.L. Hahn, o.c., 11-13; Cf. J.N.D. Kelly, o.c., 92s (trad. españ., 117s). A este respecto, Cf. infra, 54, n. 38 (bibliogr.). 111a. Así lo insinúa explícitamente san Ireneo, mencionando. «la Regla de la verdad recibida mediante el bautismo...» (Adv. Haer., I 9,4). Sobre la relación entre «el Símbolo» y «la Regla de fe», Cf.: D. van den Eynde, Les normes de l'enseignement chrétien dans la literature patristique des trois premiers siècles, GemblouxParis 1933, 280-313; B. Haegelund, Die Bedeutung «regula fidei» als Grundlage theologischer Aussagen: St Th 12 (1958) 1-44: 3-4; C. Eichenseer, o.c., 108-24; J. Quasten, art. Regula fidei: LThK, VIII 1102s (bibliogr.); Th. Camelot, Símbolos de la fe: SM V (Barcelona 1976) 359-66: 364s; J.N.D. Kelly, o.c., 76-82 (trad. españ., 99-112). 112. Did. 7,1.3. 113. 1Apol. 61,3.10. Los textos confesionales de san Justino en: A. Hahn-G.L. Hahn, o.c., 4-5; J.N.D. Kelly, o.c., 71-75 (trad. españ., 94-98). 114. Cf. Adv. Haer., III, 17,1; Exposición, 3.7.10. 115. Cf. De spect., 4; De corona, 3,2-3; Adv. Prax., 26,9; De bapt., 6,2. Los textos de Tertuliano en: A. Hahn-G.L. Hahn, o.c., 9-11 (reconstrucción de su Credo: $I b .$, 54s); Cf. J.N.D. Kelly, o.c., 85s (trad. españ., 108-110). 


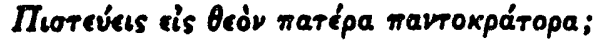

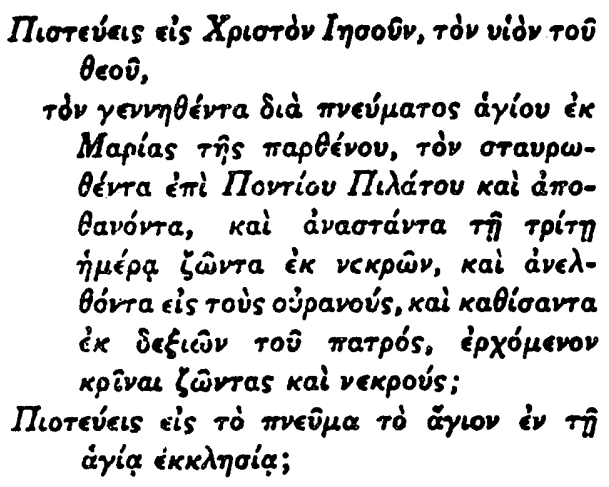

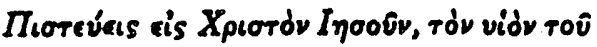
Beov,

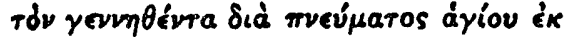
Mapias Tîs naplévov, tòy oraupw-

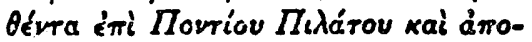

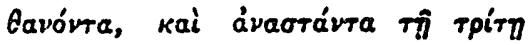

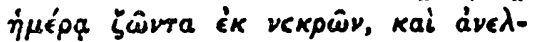
Góvra eis roùs ojpavoús, xai kabiøarra

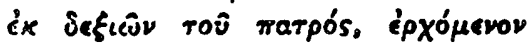

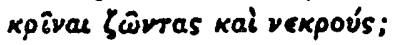

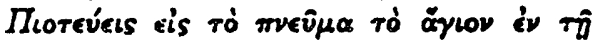

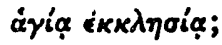

[Credis in deum patremomnipotentem?]

Credis in Christum Iesum, fiilium dei, qui natus est de Spiritu sancto ex Maria virgine, et crucifixus sub Pontio Pilato et mortuus est [et sepultus], et resurrexit die tertia vivus a mortuis et ascendit in caelis et sedit ad dexteram patris, venturus iudicare vivos et mortuos?

Credis in Spiritu sancto et sanctam ecclesiam et carnis resurrectionem? ${ }^{116}$.

La tercera pregunta es diversa en el texto griego y en la trad. latina, la cual — según las últimas investigaciones- nos conservó mejor la forma literaria original, cuya versión hispana reza:

- ¿Crees en Dios, Padre omnipotente?

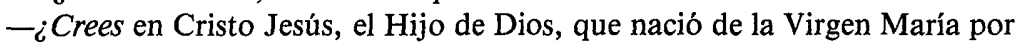
obra del Espíritu Santo, fue crucificado bajo Poncio Pilato, resucitó al tercer día de entre los muertos, subió al cielo, está sentado a la derecha del Padre y vendrá a juzgar a los vivos y a los muertos?

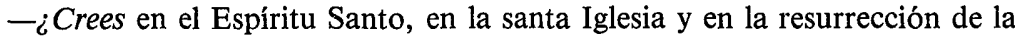
carne?».

La estructura ternaria del Símbolo (cf. infra), reflejada en este triple interrogatorio bautismal, es evidente: «No se puede negar, que tenemos ante nosotros un Credo formal y completo» ${ }^{117}$, es decir, el Símbolo de la Fe profesado en el bautismo ${ }^{118}$.

116. Trad. Apost., 17-21:21 (texto original en: A. Hahn-G.L. Hahn, o.c., 35; J.N.D. Kelly, o.c., 91: trad. españ., 116); a ete respecto, Cf.: F. Kattenbusch, o.c., II 354-60; R.H. Connolly, On the text of the baptismal Creed of Hippolitus: JThSt 25 (1924) 131-39; B. Botte, Note sur le symbol baptismal de saint Hippolyte: «Mél. J. de Ghellinck», I, Paris 1951, 189-200; J.N.D. Kelly, o.c., 45-46.89-91 (trad. españ., 63-64.113-17); D.L. Holland, The baptismal interrogation concerning the Holy Spirit in Hippolytus' Apostolic Tradition: StPatr 10 (1970) 360-65; Id., "Credis in Spiritum Sanctum et sanctam ecclesiam et resurrectionem carnis?»: Ein Beitrag zur Geschichte des Apostolikums: ZNW 61 (1970) 126-44; Id., The third article of the Creed: $A$ study in second-and third-century theology: StPatr 13 (1975) 189-97: En estos estudios (sobre todo ZNW 61) demuestra exhaustivamente el autor, que el tercer interrogante de san Hipólito se ha conservado mejor en la trad. latina, cuya versión española ofrecemos. 117. J.N.D. Kelly, o.c., 91 (trad. españ., 116). 118. Cf. a este respecto: F. Kattenbusch, o.c., II 37-55; G. Bareille, Catéchèse, en: DThC, II 1877-95: 1885s; H. Leclercq, a.c., (supra, n. 2), 1766-69; Id., Catéchèse: DACL, II 2530-79:2543-46; F.T. Dölger, Die Eingliederung des Taufsymbols in den Taufvollzug (AuC, IV), Münster 1934; H.J. Carpenter, Creed and baptismal rites in the first four centuries: JThSt 44 (1943) 1-11; J.H. Crehan, Early christian baptism and the Creed, London 1950; C. Eichenseer, o.c., 133-145. Más bibliografía, infra, n. 128. Sobre el uso litúrgico del Símbolo, en general, Cf. también I. Oñatibia, Símbolos de la fe y celebración litúrgica: Phase 13 (1973) 9-22. 
2) Así lo afirman varios de los grandes Padres de la Iglesia, desde el s. IIr. Ya san CIPRIANO (a. 255) asegura que «la Iglesia católica... bautiza... con el Símbolo», confesando la fe «en Dios Padre» y en «el Hijo Jesucristo» y en «el Espíritu Santo... a raíz del interrogatorio bautismal», completado con la pregunta: $«$ ¿Crees en el perdón de los pecados y en la vida eterna por la santa Iglesia?» "119; tal es "el Símbolo de la Trinidad», profesado durante «el bautismo en el nombre del Padre y del Hijo y del Espíritu Santo» ${ }^{120}$. Testimonios análogos y explícitos of recen luego tanto algunos PADRES CAPADOCIOS como san AMBROSIO ${ }^{121}$, san AGUSTÍN ${ }^{122}$ y, más tarde, el SACRAMENTARIO GELASIANO, completando la última pregunta con la profesión de fe «en la santa Iglesia, el perdón de los pecados y la resurrección de la carne» ${ }^{123}$. Esa confesión tenía lugar en Oriente antes de la inmersión, como lo atestiguan san CIRILO jerosolimitano ${ }^{124}$, TEODORO de Mopsuestia ${ }^{125} \mathrm{y}$ otros autores ${ }^{126}$. Pero, en ambos casos, aquella confesión compendiaba «la fe» cristiana, por ser su «cifra» $\mathrm{y}$ «sucinta fórmula» ${ }^{127}$. De ahí el esmero de la Iglesia por preparar a los catecúmenos a su profesión consciente. Lo hizo ya probablemente desde el s. III y, ciertamente, en el s. IV - no tenemos noticias antes- con los ritos solemnes de la «traditio Symboli» y la «redditio Symboli» ${ }^{128}$, mediante los cuales se les «entregaba la Fe santa y apostólica [=Símbolo], para que la confesasen» ${ }^{129}$, por ser esa Fe «el Símbolo de la sacrosanta confesión, que habéis recibido todos a la vez y habéis recitado uno por uno» ${ }^{130}$ :

119. Epist. 69,7. 120. Epist. 75,11. 121. Cf. San Ambrosio, De sacram., 2,7. El Símbolo, con el que «bautizamos en la Trinidad consustancial según el precepto de nuestro mismo Señor Jesucristo» [ = Mt 28,19], resume cuanto «en la Sagrada Escritura se dice del Padre, del Hijo $y$ del Espíritu Santo», (San Basilio, De fide, 3-4); pues «la Confesión» [ =Símbolo], dada a quienes se sumergen «en las aguas del bautismo», compendia la profesión de «la fe en el nombre del Padre, del Hijo y del Espíritu Santo»: San Gregorio Naz., Orat. 40,39-44. De modo análogo se expresa un Padre antioqueno: El bautismal Símbolo trinitario es «la perfecta profesión de la fe»: San Juan Cris., Cat. baut., V $24 . \quad$ 122. De bapt. contr. Don., 15,35; Cf. también: De fide et op., 9,14; Epist. 98,5. 123. Cf. J.N.D. Kelly, o.c., 37 (trad. españ., 55); así también el Anónimo (s. V), Testamentum Domini: J.N.D. Kelly, o.c., 35 (trad. españ., 52s). 124. Cf. Cat. XIX 9: Texto de «la Fe» (=Símbolo) en Cat. V 12. 125. Hom. XII 27-28. 126. Cf. San Juan. Cris., In 1Cor 15,29 (PG 61,348); Const. Apost., 39. 127. Cf. supra, 45. 128. Cf. San Cirilo J., Cat. V 12; XV 2; XVIII 32; Egeria, Itinerario, 46; Nicetas R., Explan. Symboli, 13; San Agustin, De fide et symbolo, I 1 ; Serm. 56,1; 57,2; 58,1; 59,1; 212,1;215,1; Conf. VIII 2,4-5; Rufino A., Expos. sumboli, 13; San Pedro Cris., Serm. 56 (PL 52,355s). 59 (PL 52,362). 60 (PL 52,366), y otros. A este respecto, Cf.: F. Kattenbusch, o.c., II 47-53.399-401; F. Wiegang, Die Stellung des Apostolischen Symbols im kirchlichen Leben des Mittelalters. I. Symbol und Katechumenat, Leipzig 1899 (repr. Darmstadt 1972); L. Duchesne, Origines du culte chrétien, Paris 1909, 309-60:319-22; G. Bareille, Catéchumenat: DThC, II 1968-87:1978-85; H. Leclercq, a.c., (supra, n. 2), 1766-69; Id., Catéchèse-Catéchisme-Catéchumene: DACL, II 2530-79:2543-46; P. de Puniet, Catéchumenat: DACL, II 2579-2621:2595-2616; M. Righetti, Historia de la Liturgia, Madrid 1956, 649-82:663-65.680s; K. Jansen, Katechumenat: RGG, III 1189-90:1190; J.A. Jungmann, Katechumenat: LThK, VI 51-55:52s; J. Daniélou, La catechesi nei primi secoli (trad. ital.), Torino 1969, 49-51; A. Laurentin-M. Dujarier, Catéchumenat, Paris 1969, 247-49. Más bibliografía, infra, 55 (n. 50: en Milán). 55 (n. 65: en África). 129. San Cirilo Jer., Cat. XVIII 32; Cf. XV 2. «Esta es la Confesión [=Símbolo], que hoy os entrego» a quienes «voy a sumergir 
a) La «traditio Symboli» u oficial entrega del Credo a los catecúmenos, tenía lugar -el sábado de la segunda semana antes de Pascua - en un sugestivo acto litúrgico, mediante el cual la Iglesia - representada por el obispo y su presbiterio con los fieles- transmitía a los «iluminados» [Jerusalén] o «competentes» [ = África] "el tesoro de la vida» ${ }^{131}$ o la $\mathrm{Fe}$ recibida de los apóstoles, aprendiendo así aquéllos lo que deben «creer con el corazón, para conseguir la justicia» (Rm 10,10a). Debían, en efecto, aprender de memoria el Símbolo y «esculpirlo en el corazón» ${ }^{132}$, sin escribirlo «en pergaminos» ${ }^{133}$, a fin que no lo olvidasen ${ }^{134} \mathrm{y}$ - también - para que «el sacramento de la fe no sea públicamente divulgado, ni llegue al infiel el arcano de la fe» ${ }^{135}$. ¡El conocimiento del Símbolo por el pagano, sin previa explicación de sus verdades, podría obstaculizar su acercamiento a la fe cristiana! Durante quince días, por tanto, aquéllos tenían que memorizar y experimentar la fe recibida. Una experiencia del Símbolo acompañada y fomentada con la esmerada explicación del mismo por el obispo, terminada la cual tenía lugar:

b) La «redditio Symboli» o solemne confesión «con la boca» de la fe re-

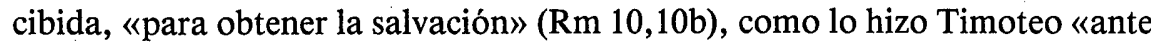
muchos testigos» $(1 \mathrm{Tim} 6,12)^{136}$. También esta pública profesión del Símbolo $\mathrm{o}$ "confesión de la fe» ${ }^{136 a}$ se realizaba en un rito del todo sugestivo, aunque no uniforme en todas las iglesias: mientras que en Jerusalén, «uno por uno» de los «iluminados» - acompañado de sus padrinos - «entregaba el Símbolo» al obispo «al comienzo [= Domingo de Ramos] de la Semana Mayor» ${ }^{137}$, en

en las aguas del bautismo», pues «seréis bautizados profesando esta fe»: San Gregorio Naz., Orat. 40,39-43. 130. San Agustín, Serm. 215,1; Cf. Serm. 57,2; 58,1; Nicetas R., o.c., 13. 131. San Cirilo J., Cat. V 13; el Símbolo es «el tesoro de nuestro pecho» (San Ambrosio, Explan. Symboli, 1) o «un don divino»: San Pedro Cris., Serm. 59: PL 52,362. 132. San Cirilo J., Cat. V 12; Cf. también: Teodoro M., Hom. X 23; San Ambrosio, o.c., 2.9; Rufino A., o.c., 2; San Agustín; De fide et symbolo, I 1; Serm. 58,1.13; 213,10; 214,1.2; Sermo ad catech. de Symb., 1; San Quodvultdeus, Serm. II de Symb., I, 1; Sacram. Gelas., 35 (PL 74,1089); San Pedro Cris., Serm. 56 (PL 52,356). 57 (ib. 360). 58 (ib. 361). 59 (ib. 365). 60 (ib. 368). 61 (ib. 369.371). 62 (ib. 372); San Ildefonso T., De cogn. bapt., 33. 133. San Cirilo J., Cat. V 12; así también: San Ambrosio, o.c., 9; Rufino A., o.c., 2; San Agustín, Serm. 214,1; Serm. ad catech. de Symb., 1; San Pedro Cris., Serm. 56 (PL 52,356). 57 (ib. 360). 134. San Ambrosio, o.c., 9. 135. San Pedro Cris., Serm. 61 (PL 52,371); Cf. también: Id., Serm. 56 (ib. 356). 57 (ib. 360). 58 (ib. 361). 59 (ib. 365); Rufino, A., o.c., 2; San Ildefonso T., o.c., 33. Sobre la «disciplina del arcano» con respecto a Símbolo, Cf.: F. Kattenbusch, o.c., II 39s. 136. Cf. San Cirilo J., Cat. V 13; Nicetas R., o.c., 2; San Agustín, Serm. 56,1; 57,1; 58,1; 59,1; 214,1; San Pedro Cris., Serm. 56 (PL 52,356). 62 (ib. 372). Ese rito de la «redditio Symboli», a imitación de la solemne «confesión pública» tanto de Jesús $(1$ Tim 6,13$)$ como de Timoteo $(1$ Tim 6,12$)$, tiene raíces veterotestamentarias: $\mathrm{El}$ «Credo histórico» de Israel (Dt 26,5b-10) es «pronunciado» por el creyente públicamente en el Templo (Dt 26,4-5a); Cf. C. Westermann, Dieu dans l'Ancien Testament, París 1982, 38. 136a. Así es designado el Símbolo por los Padres: «La Confesión de la fe» (San Cirilo J., Cat. XVII 3; Teodoro M., Hom. I 14; II 14; VI 15; IX 13.22.23; san Pedro Cris., Serm. 56 [PL 52,356A]. 69, Ib., 396B), «nuestra Confesión» (San Agustín, Enchir., 96), «la Confesión de los fieles» (San Agustín, De Civ. Dei, VII 4,9) o simplemente «la Confesión»: Teodoro M., Hom. I 6,7; San Agustín, Enchir., 64. 137. Egeria, o.c., 46,3. 
África devolvían el Símbolo «los competentes» una vez ocho días antes de Pascua y, de modo solemne, el Sábado Santo antes de ser bautizados ${ }^{138}$. Ésta debió ser también la praxis en Milán y en Roma, como lo refleja el informe agustiniano sobre la solemne "profesión de fe» cristiana en esta última ciudad por el retórico y filósofo Mario Victorino, «en presencia del Pueblo santo» $\mathrm{y}$ «con gran entereza», deviniendo así públicamente lo que antes - por temor y vergüenza - rehusaba ser: Un miembro de «la Iglesia de Cristọ» ${ }^{139}$. Pues eso hace ya el Símbolo de quien - aunque no bautizado- lo conoce y profesa: «un fiel cristiano» ${ }^{140}$.

\section{El Credo teológico de la Iglesia}

La bautismal confesión de Fe no es, sin embargo, el único testimonio de la Iglesia antigua sobre el Símbolo. Éste, en efecto, debía ser profesado diariamente por los «fieles», como distintivo o «signo de la fe» cristiana, en contraposición a su «extraño y enemigo» ${ }^{141}$. Es, pues, normal, que existiesen Símbolos derivados aunque no necesariamente vinculados a la profesión bautismal:

1) En efecto, ya en el s. III — probablemente a finales del s. II- la Iglesia de Roma poseía una confesión de Fe, trinitariamente estructurada, conocida como el Símbolo romano. Nos ha sido conservado en griego por una profesión de fe, que Marcelo de Ancira escribió al papa Julió I (ca. 356), ofreciéndonos Rufino de Aquileia (ca. 404) su -ligeramente diversa - forma latina:

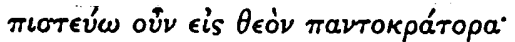

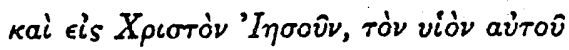

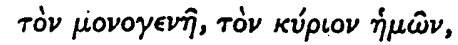

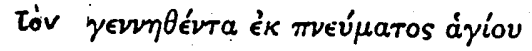

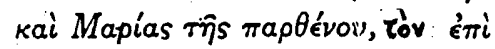

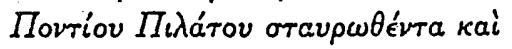

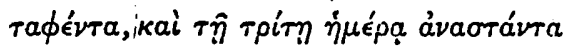

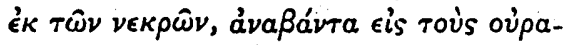

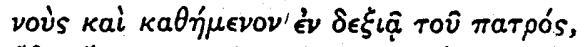

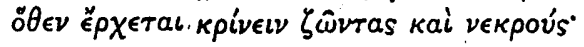

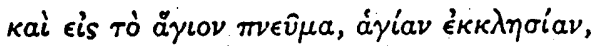

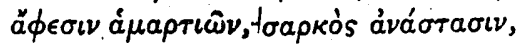
$\zeta \omega \dot{\eta} \nu$ aí́viov.
Credo in deum patrem omnipotentem;

et in Christum Iesum filium eius unicum, dominum nostrum, qui natus est de Spiritu sancto et Maria virgine, quis sub Pontio Pilato crucifixus est et sepultus, tertia die resurrexit a mortuis, ascendit in caelos, sedet ad dexteram patris, unde venturus est iudicare vivos et mortuos;

et in Spiritum Sanctum, sanctam ecclesiam, remisisonem peccatorum, carnis resurrectionem.

138. Cf. San Agustín, Serm. 58,1; 59,1; 213,8. 139. San Agustín, Conf. VIII 2,4-5. 140. San Agustín, Serm. 214,12. Así se expresa también el hodierno Magisterio de la Iglesia, afirmando que «los catecúmenos pertenecen al Pueblo de Dios», por «estar ya vinculados a la Iglesia, ser ya de la casa de Cristo y vivir con frecuencia una vida de fe, de esperanza y de caridad»: Conc. Vat. II, Decr. AG 14; Cf. también Codex Iuris Canonici (Ciudad del Vaticano 1983), can. 206. 141. Cfr. supra, 42 . 
La omisión del vocablo «Padre» en el primer artículo, así como la adición final «vida eterna», son las más importantes variantes del texto griego respecto a su forma latina, cuya versión hispana ofrecemos:

«Creo:

-en Dios, Padre todopoderoso;

-y en Cristo Jesús su único Hijo, nuestro Señor, que nació del Espíritu Santo y de María Virgen, que bajo Poncio Pilato fue crucificado y sepultado, al tercer día resucitó de entre los muertos, subió al cielo, está sentado a la derecha del Padre, de donde vendrá a juzgar a los vivos y a los muertos;

-y en el Espíritu Santo, la santa Iglesia, el perdón de los pecados, la resurrección de la carne» ${ }^{142}$.

Este Símbolo de Roma - regla o norma de la fe cristiana- fue la base del texto recibido por todos los Símbolos Occidentales, al que interpretan con ligeras variantes y ampliaciones textuales ${ }^{143}$. También los Credos Orientales reflejan la interpretación teológica de una antigua profesión de fe ${ }^{144}$, siendo por

142. El texto griego + latino (de Marcelo A. y Rufino A.) es ofrecido por: A. Hahn-G.L. Hahn, o.c., 22-25; J.N.D. Kelly, o.c., 102s (trad. españ., 128s). Sobre el Símbolo Romano; Cf.: A. Harnack, a.c., 743-45; Id., o.c., 10-11; Id., Materialien zur Géschichte und Erklärung des al ten römischen Symbols aus der christlichen Literatur der zwei ersten Jahrhunderten: A. HahnG.L. Hahn, o.c., 364-90; A.E. Burn, o.c., 45-66: 198-201; F. Kattenbusch, o.c., I 59-77; II 471728; P. Battifol, a.c., 1668-73; G. Krüger, Das Taufbekenntnis der römischen Gemeinde als Niederschlag des Kampfes gegen Marcion: ZNW 6 (1905) 72-79; F.J. Bacock, The old Roman Creed: JThSt 23 (1922) 362-89; B. Capelle, Le Symbole Romain au II siècle: RBén 39 (1927) 37-45; Id., Les origines du Symbole Romain: RThAM 15 (1930) 5-20; H.J. Carpenter, The Birth from the Holy Spirit and the Virgin in the Old Roman Creed, en: JThS 40 (1939) 31-36; H. Lietzmann, Symbolstudien, II-IX: «Kleine Schriften», III 192-229; D. Holland, The earliest text of the old Roman Creed: ChH 34 (1965): 251-81; 'A. Adam, Lehrbuch der Dogmengeschichte, I, Gütersloh 21976, 194-98; P. Smulders, The Sitz im Leben of the old Roman Creed. New conclusion from neglected data: StPatr 13 (1975-76) 409-21; J.N.D. Kelly, o.c., 100-166 (trad. españ. 125-201). Sobre la estructura rítmica del texto latino, Cf. H. Jordan, Rytmische Prosa in der altchristlichen lateinischen Literatur, Leipzig 1905, 35-38. La ausencia de polémica antidoceta y antigṇóstica en el contexto inmediato de las confesiones de fe y fórmulas bautismales de san Justino, San Ireneo y Tertuliano (Cf. supra, 18, nn. 106-115) así como la previa instrucción catequética al trinitario interrogatorio bautismal de la Iglesia romana (Hipólito R., Trad. Apost., 17-18.21; Cf. san Justino, IApol., 61, 2-3) muestra, que el Símbolo romano se formó no directamente como reacción antignóstica (contra: A.C. McGiffert, o.c., 62s; G. Krüger, a.c., 77ss; A. Harnack, Marcion, Leipzig 21924, 316*, n. 2: «...no sería improbable...»), sino como normal desarrollo de la fórmula bautismal trinitaria (Mt 28,19) y, a la vez, compendio de la recibida instrucción catequética: Cf. J.N.D. Kelly, o.c., 145s (trad. españ., 177s), y otros autores (supra, 17, n. 99). 143. Cf.: A. Harnack, a.c., 745-47; F. Kattenbusch, o.c., I 78-215; J.N.D. Kelly, o.c., 172-181 (trad. españ.) 209-219). 144. No unánimemente determinada por los especialistas: Mientras algunos la identifican con el Símbolo romano (así F. Kattenbusch, o.c., I 368-92: 389s), otros postulan una diferente profesión original (así H. Lietzmann, o.c., 194-203), atribuyendo otros la formación de aquellos Credos a raíz de la triple confesión bautismal (J.N.D. Kelly, o.c., 198-201: trad. españ., 238-41; Cf. A.E. Burn, o.c., 70), en la que se enraizarían tanto los Credos occidentales como los orientales (Id., o.c., 201-3: trad. españ., 241-45). Del todo instructivos, a este respecto, son los análisis dè A. Harnack, (a.c., 747-52), según el cual los Símbolos orientales surgieron (desde finales del s. III) a raíz de una antigua «formula cristológica» y de antiguas «fórmulas bautismales», 
ello generalmente más amplios que los occidentales ${ }^{145}$ : es lo que acusa el texto del Símbolo cesariense ${ }^{146}$, jerosolimitano ${ }^{147}$ y antioqueno ${ }^{148}$, en los que la reacción antiherética impuso el retoque del texto base.

2) Como teológica interpretación de un antiguo (bautismal) Credo oriental en reacción antiarriana, formularon asimismo en Nicea los padres del primer concilio ecuménico (a. 325) una profesión de la fe ortodoxa en el Símbolo Niceno:

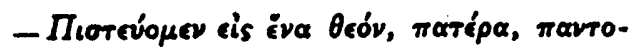

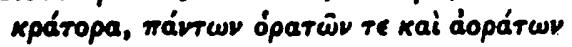
mointiviv.

- Kai eis èva kúplov 'I Toov̂v Xpcotóv, tòv

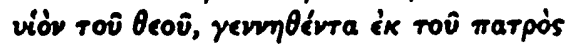

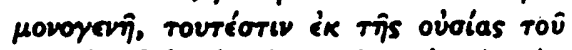

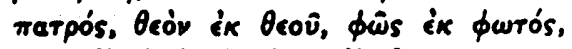

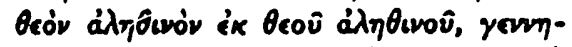

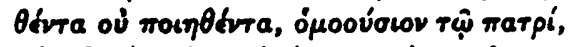

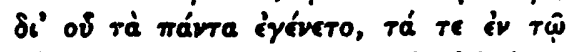

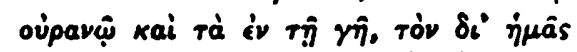

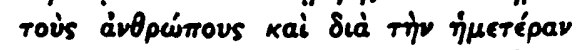

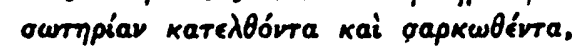

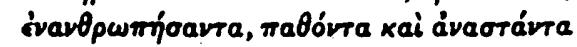

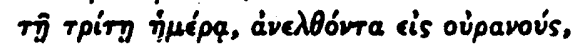

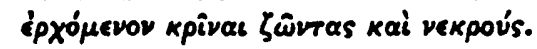

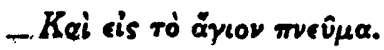

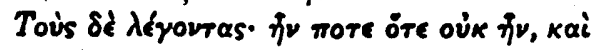

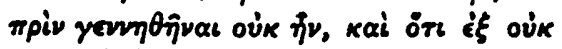

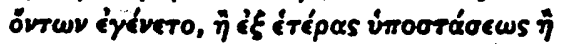

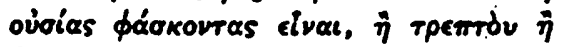

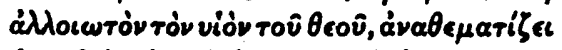

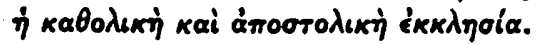

-Creemos en un solo Dios, Padre todopoderoso, creador de todas las cosas, visibles e invisibles.

- $\mathrm{Y}$ en un solo Señor Jesucristo, el Hijo de Dios, engendrado por el $\mathrm{Pa}$ re, unigénito, o sea, de la sustancia del Padre, Dios de Dios, luz de luz, Dios verdadero de Dios verdadero, engendrado, no creado, consustancial con el Padre, por quien todo fue hecho, en el cielo y en la tierra, que por nosotros los hombres y por nuestra salvación bajó y se encarnó, se hizo hombre, padeció y resucitó al tercer día, subió a los cielos, volverá a juzgar a los vivos y a los muertos.

-Y en el Espíritu Santo.

$\mathrm{Y}$ a los que dicen que hubo tiempo en que no existió, que no existió antes de nacer y que comenzó a existir de la nada, y a los que afirman que el Hijo de Dios es de una hipóstasis o sustancia diferente o que está sujeto a alteración o cambio - a éstos la Iglesia católica y apostólica los anatematiza ${ }^{149}$.

no antes de que se hubiese «aprendido a conocer y valorar el Símbolo romano» (749; Cf. 752), siendo en todo caso «hazaña de la Iglesia romana haber creado el Símbolo y, con él, el fundamento de todos los Símbolos eclesiásticos» (752: Lo cursivo es nuestro). 145. Cf. F. Kattenbusch, o.c., I 216-392; II 180-277; H. Lietzmann, Symbolstudien, II-IV: «Kleine Schriften», III 192-213; J.N.D. Kelly, o.c., 181-201 (trad. españ., 219-233). 146. Texto reproducido por A. HanhnG.L. Hahn, o.c., 131s; Cf. F. Kattenbusch, o.c., I 228-233; J.N.D. Kelly, o.c., 182s (trad. españ., 220s). 147. Texto reproducido por A. Hahn-G.L. Hahn, o.c., 132-34; Cf. A.E. Burn, o.c., 66-69; F. Kattenbusch, o.c., I 233-244; J.N.D. Kelly, o.c., 183s (trad. españ., 221s). 148. Texto en A. Hahn-G.L. Hahn, o.c., 141-43.302.380; Cf. F. Kattenbusch, o.c., I 220-23; J.N.D. Kelly, o.c., 185s.187s (trad. españ., 223-24.226s). 149. Texto griego en: A. Hahn-G.L. Hahn, o.c., 160s; J.N.D. Kelly, o.c., 215s (trad. españ. 259); excelente edición crítica y comentario ofrece G.L. Dossetti, Il Simbolo di Nicea e di Constantinopoli, Roma 1976, 29-167.277-84. 
Por vez primera los pastores de la Iglesia usaron la confesión bautismal, para definir la norma o regla de fe ortodoxa, de modo que el catequético Símbolo de los catecúmenos devino el Credo teológico de los obispos y teólogos. Se comprende, pues, la escasa resonancia del Símbolo niceno en la vida de la Iglesia, durante los años siguientes a su formulación: ¡La pastoral del Bautismo así como la praxis cristiana seguía su propio camino! ${ }^{150}$.

También las discusiones teológicas continuaban su curso, hasta que el concilio constantinopolitano I (a. 381), reaccionando contra las nuevas formas del arrianismo así como respondiendo a quienes negaban la divinidad del Espíritu Santo, juzgó necesario reinterpretar el Credo niceno en una nueva norma de la ortodoxia o Confesión de $\mathrm{Fe}$, - - solemnemente leída luego (a. 451) durante el concilio calcedonense y reinterpretada por otros Símbolos ${ }^{151}$-, conocida como el Símbolo constantinopolitano:

Sobre el Símbolo niceno, expresión de «la fe profesada por los padres según las Escrituras» (San Atanasio, Ad Epict., 1), Cf. también: Anónimo (finales s. IV), Commentarius in Symbolum Nicaenum: PLS, I 219-40; F.J.A. Hort, Two Dissertations, I, Cambridge 1876, 54-72; A.E. Burn, o.c., 98-106; F. Kattenbusch, o.c., I 228-233; F. Loofs, Das Nicaenum: «Fs. K. Müller», Tübingen 1922, 68-82; R. Seeberg, Lehrbuch der Dogmengeschichte, II, Erlangen-Leipzig 1923, 41-45; A. D'Alès, Le dogme de Nicée, Paris 1936, 243-70; I. Ortiz de Urbina, El Símbolo niceno, Madrid 1947; Id., Das Glaubensbekenntnis des I. Konzils von Nikaia: LThK, VII 968s; Th. Camelot, «Symbole de Nicée» ou Foi de Nicée?: OCP 13 (1947) 425-33; H. Lietzmann, Symbolstudien, XIII-XIV: «Kleine Schriften», III 248-60; H. Vogel, Das nicaenische Glaubensbekenntnis. Eine Doxologie, Berlin 1963; A. Adam, o.c., II 223-26; B. Welte, Die Lehrformel von Nikaia und die abendländische Metaphysik: «Zur Frühgeschichte der Christologie» (QD 51), Freiburg 1970, 100117; D. Perezil, Le Symbole de Nicée hier et aujourd'hui, en: AA.VV., «La foi de l'Eglise», Paris 1978, 17-45; R. E. Person, The method of theological decision making at the early Ecumenical Councils, Basel 1978, 71-104; J.N.D. Kelly, o.c., 215-254 (trad. españ., 247-303); A.M. Ritter, Dogma und Lehre in der Alten Kirche: «Die Lehrentwicklung im Rahmen der Katholizität», Göttingen 1982, 98-283: 163-170 (bibliogr.). 150. Cf. J.N.D. Kelly, o.c., 254-62 (trad. españ., 303-313). 151. Ya por el Símbolo de Calcedonia (a. 451: Cf. H. Bacht-A. Grillmeier, Chalkedon. II: LThK, II 1006-9: 1007ss; I. Ortiz de Urbina, Das Glaubekenntnis von Chalkedon - sein Text, sein Werden, seine dogmatische Bedeutung: «Das Konzil von Chalkedon» (Hrsg. A. Grillmeier-H. Bacht), I, Würzburg 21959, 389-418: 406ss; E.L. Fotin, The Definitio fidei of Chalcedon and its philosophical sources: StPatr 5[1960] 489-98; J. Liebaert, Christologie. Von der Apostolischen Zeit bis zum Konzil von Chalcedon [HDG III. 1a], Freiburg 1965, 123-126; K. Baus-E. Ewig, El sínodo ecuménico de Calcedonia (451): MHE, II, Barcelona 1980, 172-81: $176 \mathrm{ss}$, formulado «como explicación del Símbolo niceno y contantinopolitano» (A. Grillmeier, a.c., 1008), como lo hará luego el Símbolo atanasiano (texto en: A. Hahn-G.L. Hahn, o.c., 17477; Denz. 39-40), compuesto probablemente en la segunda mitad del s. V y de origen galicano: Cf. A.E. Burn, o.c., 124-149; Id., The Athanasian Creed, Oxford 1912; J. Quasten, Patrologia, II, Madrid 1962, 34-36 (bibliogr.); J.N.D. Kelly, The Athanasian Creed, London 1964; J.M. Perrosanz, El Símbolo atanasiano, Madrid 1976. 


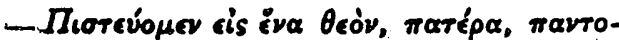

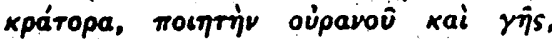

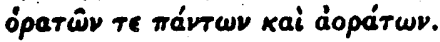

- Kai eis ¿̇va xúplov 'I '̄ooûv Xplotóv, tòv

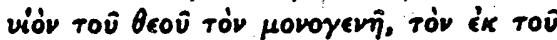

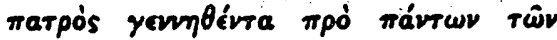

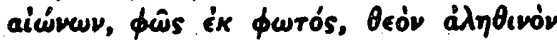

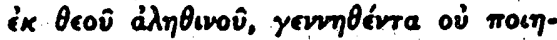

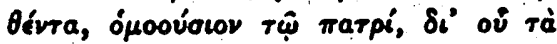

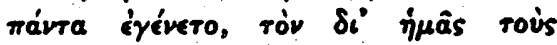

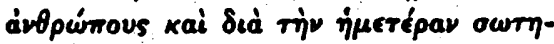

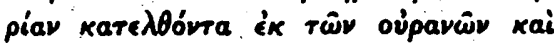

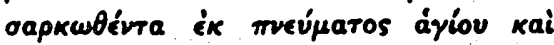

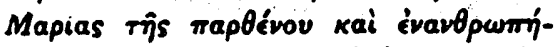

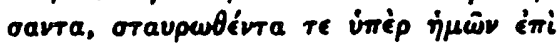
Movríov IIlárov, кai таbóıтa кai.

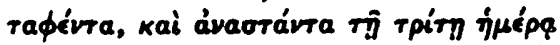

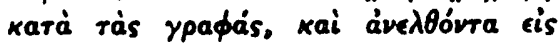
roùs. oujpavoús, rai rabeלóptwov iv

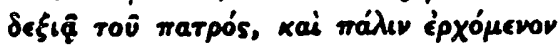

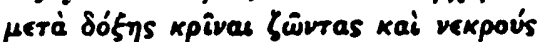

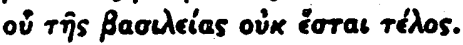

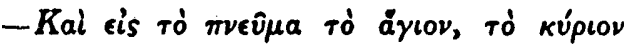

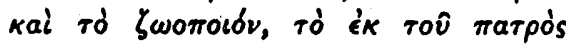

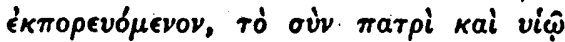

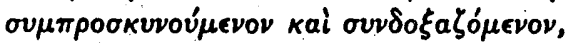

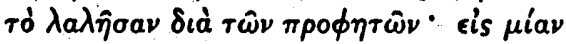

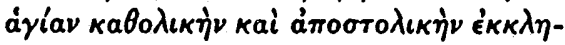

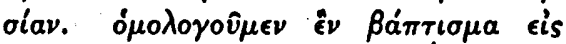

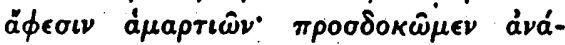

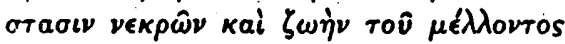

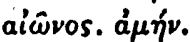

-Creemos en un solo Dios, Padre todopoderoso, creador del cielo y tierra, de todo lo visible y lo invisible.

-Y en un solo Señor Jesucristo, el unigénito Hijo de Dios, engendrado por el Padre antes de todos los tiempos, luz de luz, Dios verdadero de Dios verdadero, engendrado no creado, por el que todo fue hecho, que por nosotros los hombres y por nuestra salvación bajó de los cielos y se encarnó por el Espíritu Santo y María la Virgen y se hizo hombre, y por nosotros fue crucificado por sentencia de Poncio Pilato, y padeció y fue sepultado, resucitó al tercer día, según las Escrituras, y subió a los cielos, y está sentado a la derecha del Padre y volverá con gloria a juzgar a los vivos y a los muertos, y su reino no tendrá fin.

-Y en el Espiritu Santo, el Señor y dador de vida, que procede del $\mathrm{Pa}$ dre, que con el Padre y el Hijo es adorado y glorificado, que habló por los profetas. Y en una sola Iglesia santa, católica y apostólica. Profesamos un solo bautismo para el perdón de los pecados. Esperamos la resurrección de los muertos y la vida del mundo futuro. Amén ${ }^{152}$.

152. Texto griego en A. Hahn-G.L. Hahn, o.c., 162-65; G.L. Dossetti, o.c., 244-250. Cf. a este respecto: F. Kattenbusch, o.c., I 233-44; J. Kunze, Das, nizänisch-konstantinopolitanische Symbol, Leipzig 1898 (reprod. Aalen 1972); A. D'Ales, Nicée-Constantinople. Les premiers Sym boles de foi: RSR 26 (1936) 85-92; J. Lebon, Nicée-Constantinople. Les premiers Symboles de foi: RHE 32 (1936) 537-47; I. Ortiz de Urbina, La estructura del Símbolo constantinopolitano: OrChrP 12 (1946) 275-85; Id., Nicaeno-Konstantinopolitanisches Glaubensbekenntnis: LthK, VII 938-40; E. Kähler, Nicäno-Konstantinoplitanum: RGG, IV 1454s; A-M. Ritter, Das Konzil von Konstantinopel und sein Symbol, Göttingen 1965, 132-208; Id., o.c., 206-14; B. Schultze, Das Nicaeno-Constantinopolitanum und das Filioque: OrChr 35 (1969) 334-46; A. Adam, o.c., 240-43; G.L. Dossetti, o.c., 169-284 (;excelente edicción crítica y comentario!); W. Beinert, Das

Glaubensbekenntnis der Ökumene. Eine Auslegung des grossen (nizäno-konstantinopolitanischen) Glaubensbekenntnis, Freiburg 1976, 17-142; J.D.N. Kelly, o.c., 296-367 (trad. españ., 353434); K. Baus-E. Ewig, El Símbolo de Constantinopla (381): MHE, II, Barcelona 1980, 118-24; W.D. Hausschild, Das trinitarische Dogma von 381 als Ergebnis verbindlicher Konsensbildung: «Glaubensbekenntnis und Kirchengemeinschaft» (Hrsg. v. K. Lehmann-W. Pannenberg), Frei- 
Éste es el Credo más influyente en la Iglesia, a partir del s. IV: Reinterpretado - contra los monotelistas- por el CONC. de LETRÁN (a. 649) ${ }^{153}$, y más ampliamente - contra los priscilianistas - por el XI CONC. de TOLEDO (a. 675) ${ }^{154}$ así como por LEÓN IX (a. 1053) en la Profesión de Fe obligatoria para la consagración episcopal ${ }^{155}$, aquél fue reasumido sustancialmente -con ligeras ampliaciones - ya por el I-II CONC. de TOLEDo (a. 400.447) ${ }^{156} \mathrm{y}$, más tarde, por Pío IV (a. 1564) en su "Profesión de fe tridentina» ${ }^{157}$; fue, pues, desde el s. V una de las principales teológicas «Reglas de Fe», usadas por la Iglesia contra los herejes en la determinación y definición de sus verdades dogmáticas. Litúrgicamente ocupó también ese Símbolo un puesto central ${ }^{158}$. Si en Oriente (desde el s. VI) y en Occidente (desde el s. IX) devino el Símbolo bautismal, a partir del s. VI fue introducido (por vez primera en España) en la santa Misa, durante cuya celebración lo recitaron los fieles en los siglos siguientes. «Lejos de arrinconarlo, la reforma [protestante] reafirmó su carácter de obligatoriedad», siendo por tanto «este Credo uno de los pocos lazos, que siguen uniendo a las diferentes partes del cristianismo desgarrado» ${ }^{159}$. Y sigue aunando en la fe a los fieles católicos: Tras la reforma litúrgica impulsada por el Conc. Vaticano II, la Iglesia católica le asignó su justificado puesto tanto en la Liturgia de los catecúmenos como en la de la Misa de los fieles ${ }^{160}$, siendo asimismo ese Símbolo la profesión de fe exigida por la actual Legislación eclesiástica a quienes son promovidos tanto a las órdenes y dignidades eclesiásticas como al gobierno pastoral e institucional de las Iglesias ${ }^{161}$.

3) La sustitución del antiguo Símbolo romano por el Credo constantinopolitano en el rito bautismal, sin embargo, no fue definitiva. Ya en el s. VI aparece en el norte de España y sur de Francia una fórmula del «Credo» muy afín al Símbolo romano, que terminó por ser aceptada como texto recibido $[=\mathrm{T}]$ o forma oficial del Símbolo de los apóstoles ${ }^{162}$. Se distingue de aquél por algunas ligeras variantes y, sobre todo, por adiciones sustanciales, como son el «descenso a los infiernos» de Jesús tras su muerte, la designación de la Iglesia como «católica» y la fe en «la comunión de los santos», así como la conclusiva mención de «la vida eterna» ${ }^{163}$.

burg-Göttingen 1982, 13-48. 153. Cf. Denz. 254-269; ya en el s. V por el Símbolo Calcedonense y el Símbolo Atanasiano: Cf. supra, n. 151. 154. Texto latino en: A. Hahn-G.L. Hahn, o.c., 242-48; Denz. 275-87. Cf. a este respecto: J.A. de Aldama, El Símbolo toledano (AG. 7), Roma 1934; J. Madoz, Le Symbole du XI ${ }^{e}$ Concile de Tolède, Louvain 1938; Id., El Símbolo del conc. XVI de Toledo, Madrid 1946; J. de Pérez, La cristología de los Símbolos toledanos IV, VIy XI, Roma 1939. 155. Cf. Denz. 343-49. 156. Cf. Denz. 19. 157. Cf. Denz. 994-100: 994; Cf. H. Jedin, Tridentinisches Glaubensbekenntnis: LThK, X 338; Id., Geschichte des Konzils von Trient, IV. 2, Freiburg 1975, 241. 158. Cf. supra, 8s, n. 23 (bibliogr.). 159. J.N.D. Kélly, o.c., 296 (trad. españ., 354); así también W.D. Hauschild, a.c., 13. 160. Cf. S. Congregación del Culto, Rituale Romanum. Ordo initiationis christianae adultorum (Ciudad del Vaticano 1972), Nos 186-199; Pablo VI, Missale Romanum, Ciudad del Vaticano 1975, 389s. 161. Cf. Codex Iuris Canonici, can. 833 162. Cf. F. Kattenbusch, o.c., I 189-99; II 759-815; P. Battifol, a.c., 1662-65; J.N.D. Kelly, o.c., 368-434 (trad. españ., 435-509); sobre la mencionada fecha de composición y origen del T, Cf. Id., o.c., 404-20 (trad. españ., 477-93). 163. Cf. J.N.D. Kelly, o.c., 369-97 (trad. españ., 437-68). Reproducimos a continuación el texto latino ofrecido 
-Credo in deum patrem omnipotentem, creatorem coeli et terrae.

-Et in Iesum Christum, filium eius unicum, dominum nostrum, qui conceptus est de Spiritu Sancto, natus ex Maria virgine, passus sub Pontio Pilato, crucifixus, mortuus et sepultus, descendit ad inferna, tertia die resurrexit a mortuis, ascendit ad coelos, sedet ad dexteram dei patris omnipotentis, inde venturus est iudicare vivos et mortuos.

-credo in Spiritum sanctum, sanctam ecclesiam catholicam, sanctorum communionem, remissionem peccatorum, carnis resurrectionem, et vitam aeternam. Amen.
- Creo en Dios Padre todopoderoso, creador de cielo y tierra.

- $\mathrm{Y}$ en Jesucristo, su único Hijo, nuestro Señor, que fue concebido por obra del Espíritu Santo, nació de María Virgen, padeció bajo Poncio Pilato, fue crucificado, muerto y sepultado, descendió a los infiernos, resucitó al tercer día de entre los muertos, subió a los cielos, está sentado a la derecha de Dios Padre todopoderoso, desde allí ha de venir a juzgar a los vivos y a los muertos.

- Creo en el Espíritu Santo, la santa Iglesia católica, la comunión de los santos, el perdón de los pecados, la resurrección de la carne y la vida eterna. Amén.

Este ampliado texto del Símbolo romano se impuso gradualmente como fórmula de fe en las iglesias de occidente, hasta que en el s. IX adquirió ya «el monopolio» de Credo bautismal y, a partir de entonces, fue aceptado también por Roma como «el Credo oficial» ${ }^{164}$. Nada de extraño, pues, si a raíz de ese texto recibido del Símbolo apostólico redactaron su Profesión de Fe en el IV CONC. de LETRÁN (a. 1215) y el II CONC. de LIÓN (a. 1274) ${ }^{165}$, siendo asimismo el texto del Símbolo comentado por STO. TOMÁs A. (a. 1273) primero y, luego (a. 1566), por el CATECISMO.ROMANO ${ }^{166}$ : su autoridad -en el período medieval y renacentista - era indiscutible. Y fue reconocida también por los reformadores protestantes, así como - en nuestro siglo- por varias asambleas ecuménicas ${ }^{167}$, siendo ésa la fórmula preferentemente usada hoy por la Iglesia católica en la renovada Liturgia de los catecúmenos, durante el rito de la «traditio Symboli» ${ }^{168}$.

Estos precedentes desarrollos, por lo demás, son ya un claro indicio de:

por: A. Hahn-G.L. Hahn, o.c., 30s; Denz. 7; J.N.D. Kelly, o.c., 369 (trad. españ., 436). 164. J.N.D. Kelly, o.c., 426-34 (trad. españ., 501-9). 165. Cf. Denz. 428-30.461-64. 166. Cf. infra, 57s. 167. Cf. J.N.D. Kelly, o.c., 368 (trad. españ., 435s). 168. Cf. S. Congregación del Culto, o.c., (supra, n. 160), n. 186. 


\section{Actualidad del Símbolo}

El Credo de la Iglesia no es monumento literario del pasado. Aquél es, por el contrario, el siempre actual compendio de la fe cristiana, que de cada creyente exige no sólo ser personalmente creída «en el corazón» sino también ser confesada «con la boca» ( $\mathrm{Rm} 10,9-10)$, como testimonio o gozoso anuncio de «la Vida» divina manifestada en «la Palabra» encarnada, por aquél «oída» y "vista» y «contemplada» (Cf. 1Jn 1,1-3). Precisamente la fuerza ínsita en ese testimonio confiere hoy al Símbolo un puesto de relieve en la vida de la Iglesia y, ante todo, en la hodierna reflexión teológica:

\section{Actualidad teológica}

1) La hodierna renovación de los estudios teológicos, recientemente requerida e impulsada por el Conc. Vat. II «mediante un contacto más vivo con el misterio de Cristo y la historia de la salvación» (Decr. OT 17), exige una profunda reestructuración interna y externa de los diversos tratados de la teología, que satisfagan plenamente a la orientación del Magisterio conciliar. Una tarea ya ciertamente aquí y allí emprendida, pero insuficientemente lograda. Un criterio seguro, a este respecto, lo puede ofrecer la estructura misma del Credo. En efecto, si la teología está compendiada en el Símbolo, cifra y síntesis de la dogmática de la Iglesia (Cf. supra), sus tratados teológicos deberían reorganizarse interior y exteriormente ajustándose a la unitaria estructura literariamente ternaria y teológicamente trinitaria del Credo (Cf. infra), de modo que en su misma ordenación interna y externa reflejen aquéllos tanto la unidad como la jerarquía de las verdades reveladas, que integran la dogmática de la Iglesia, explicitación teológica del Símbolo: Si su «creo en» introductorio es explicitado por la introducción general a la teología [=Teología Fundamental], todos los demás tratados deberían reorganizarse y estructurarse como explicitaciones teológicas de la triple confesión en Dios Padre y Creador [ = Dios uno y trino + Cosmología teológica], en Jesucristo su Hijo y Señor [=Cristología], el cual por nosotros se encarnó, murió y resucitó [= Encarnación + Soteriología + Mariología], y en el Espíritu Santificador [= Pneumatología] mediante la Iglesia y sus sacramentos [=Eclesiología + Semeiología sacramentaria], para comunicar al hombre creyente «la vida eterna» [ = Escatología]. Toda la teología se estructura de este modo según la composición interna del Símbolo, —su raíz u origen y compendio-, al que explicita y desarrolla. Una estructuración, pues, normal y objetiva, por corresponder a la de su fuente. Más aún: aquélla tiene la ventaja no sólo de resaltar que el epicentro de toda la teología — ¡lo es del Símbolo! - es «el misterio de Cristo», según la mencionada orientación del Magisterio conciliar, sino también de subrayar la extrecha relación tanto de la Mariología con la Cristología como de la Eclesiología y Semeiología sacramentaria con la Pneumatología. Si todo esto es exacto, el Símbolo puede contribuir eficazmente a la ho- 
dierna renovación de los estudios teológicos. No es ése, sin embargo, el único ni principal motivo de su actualidad teológica.

2) También está llamado a desempeñar hoy el Credo de la Iglesia un papel decisivo, en el contexto del actual pluralismo teológico:

La libertad - natural facultad humana de elegir los medios más aptos para conseguir el propio fin ${ }^{1}$ - es constitutivo esencial del hombre. Éste, en efecto, fue creado a imagen del Dios libre ${ }^{2}$, Quien por eso quiso dejarle «en manos de su propia decisión (Eclo 15,14), para que espontáneamente busque al Creador y, adhiriéndose libremente a Él, alcance la plena bienaventuranza» ${ }^{3}$. De ahí que la libertad «acompañó y acompaña al hombre a través de su historia», como «uno de los factores más determinantes de su rumbo», pues aquél «hizo y hace historia en la medida que quiso y quiere liberarse de toda tiranía» ${ }^{4}$, consciente de que la «libertad es el mayor de los bienes» ${ }^{5}$. Esta convicción abriga sobre todo el hombre hodierno, particularmente sensible al acariciado sonido de aquel vocablo: «Nunca ha tenido el hombre un sentido tan agudo de su libertad» ${ }^{6}$. Herida ésta, sin embargo, "por el pecado», y cuyo recto uso exige por tanto de aquél «apoyarse necesariamente en la gracia de Dios» ${ }^{7}$. De ahí el empeño del actual Magisterio de la Iglesia por enseñar y fomentar el recto uso de las libertades del hombre ${ }^{8} \mathrm{y}$, entre ellas, el libre ejercicio de la cultura, reconociendo sin ambages a todos «los fieles _clérigos o laicos-la justa libertad de investigación, de pensamiento y de manifestar humilde y valerosamente su opinión en los campos que son de su competencia» ${ }^{9}$.

Es, pues, normal que los exégetas y teólogos católicos, estimulados por el mismo Magisterio «a buscar siempre un modo más apropiado de comunicar la doctrina [de la fe] a los hombres de su época» y a profundizar «en la verdad revelada sin perder contacto con su tiempo, a fin de facilitar a los hombres cultos... un más pleno conocimiento de su fe» ${ }^{10}$, hiciesen en los últimos decenios amplio uso de esa libertad, justamente reconocida. Resultado eminentemente positivo de ese ejercicio es, sin duda, el primaveral o ya estivo florecimiento de las ciencias sagradas, desembocando en un legítimo pluralismo teológico que, fiel a la Tradición apostólica - custodiada e interpretada por el

1. León XIII, Enc. Libertas praestantissimum (ASS 20 [1887] 593-613), 5; Id., Enc. Annum ingressi (ASS 34 [1901-1902] 513-22), 24 . 2. Cf. Gén 1,26-27; Jer 18,6; Rm 9,15-21; 2Cor 3,17. 3. Conc. Vat. II, Cons. GS 17; Cf. ib. 21.68. 4. S. Sabugal, ¿Liberación y secularización?: Intento de una respuesta bíblica, Barcelona 1978, 8. 5. Epicteto, Dissertationes, IV 1,52. 6. Conc. Vat. II, Const. GS 4; Cf. Pablo VI, Exh. Apost. EN 29-30. 7. Conc. Vat. II, Const. GS 17. 8. Politica (Cf. Juan XXIII, Enc. MM 97; Enc. PT 35.42-52.120-25; ( unc. Vill. 11. ('onst. (jS 31.75), socioeconómica (CF. Juan XXIII, Enc. MM 82-83.109-112; Conc. Vat. II Const. GS 66-68.71; Pablo VI, Enc. OA 47), religiosa: Cf. Conc. Vat. II, Const. LG 36; Const. GS 42.76; Decl. DH 2-8.10.13. 9. Conc. Vat. II, Const. GS 62. Sobre el tema de «la libertad en la Iglesia», Cf. K. Rahner, Escritos de Teología, II, Madrid 1961, 95-114.26974; VI, Madrid 1969, 210-32; Id., Schriften zur Theologie, X, Einsiedeln 1970, 115-32; Id., Curso fundamental de la fe, Barcelona 1979, 463s. 10. Conc. Vat. II, Const. GS 62. 
Magisterio de la Iglesia - y enraizado o anclado en la unidad de la fe cristiana, promete y está dando ricos frutos.

¡No siempre es ése el caso, sin embargo! Pues, precisamente en las últimas décadas, varios exégetas y teólogos realizán su investigación exegética y elaboran su reflexión teológica al margen o, incluso, contra la guía y enseñanza del Magisterio de la Iglesia, al que «únicamente fue confiado [por Cristo] el carisma de interpretar auténticamente la Palabra de Dios» ${ }^{11}$, dañando así gravemente la unidad dogmática del cristianismo. En efecto, ya el a. 1967 la comisión especial nombrada por el primer SíNODO EPISCOPAL denunció la existencia de serios errores teológicos ${ }^{12}$, proponiendo que «la Sede Apostólica... publique una declaración positiva y pastoral sobre las cuestiones referentes a la actual problemática doctrinal, para dirigir con seguridad la fe del Pueblo de Dios» ${ }^{13}$.

Una propuesta solícitamente acogida por el entonces Pastor supremo PABLO VI, respondiendo a los mencionados errores teológicos con su «Solemne Profesión de Fe» o «El Credo del Pueblo de Dios» ${ }^{14}$, que con agrado designaríamos el Símbolo del siglo XX: En el empeño por «conservar íntegramente el depósito de la fe (Cf. 1Tim 6,20)» cristiana y de llevarla «a la vida... en este mundo», así como consciente de tener que «cumplir el mandato confiado por Cristo a Pedro», - - en calidad de «sucesor» suyo-, es decir confirmar «en la fe a los hermanos» (Lc 22,32), el Papa decidió «hacer una profesión de fe», que «repite sustancialmente - con algunas explicaciones postuladas por las condiciones espirituales de esta época- la fórmula nicena, es decir, la fórmula de la tradición inmortal de la santa Iglesia de Dios» ${ }^{15}$; lo hizo, por lo demás, saliendo al paso de «perturbaciones» sufridas por algunos bajo el «influ-

11. Conc. Vat. II, Const. DV 10: Cf. ib., 23; Decr. OT 16; Const. LG 67. 12. En su informe sobre Las opiniones religiosas actuales y el ateismo (Cf. Ecclesia 28 [1967] 1657ss) se lamentan el que «algunos pongan realmente en duda ciertas verdades de fe, entre otras las referentes al conocimiento de Dios, a la persona de Cristo y su resurrección, a la eucaristía, al misterio del pecado original, a la objetividad permanente de la ley moral y a la perpetua virginidad de Santa María»: Ibid., 1657. 13. Ib., 1659. 14. Cf. Pablo VI, Solemnis Professio Fidei, en: AAS 60 (1968) 433-445. Las primeras ediciones en varios idiomas, hechas por la Políglota Vaticana, titularon esa Profesión de Fe (así la ed. española) El «Credo» del Pueblo de Dios; Cf. a este respecto: J. Daniélou, La profession de foi de Paul VI: Etudes (1968) 599-607; L.M. Almendáriz, Los enunciados de la fe (Cristianismo para hoy): RazFe 178 (1968) 23-40; Y Congar, Au milieu des ouragans. L'Eglise affronte aujourd'hui son avenir, Paris 1969, 58-65. El mejor comentario a ese importante documento de Pablo VI es el realizado por el teólogo español C. Pozo, El Credo del Pueblo de Dios, Madrid (1969) ${ }^{2} 1975,38-237$. 15. Pablo. VI, o.c., 1.3. Ya Sto. Tomás enseñó que «compete a la autoridad del Sumo Pontífice hacer una nueva proposición del Símbolo» o «redactar un nuevo Símbolo», puesto que «la composición de» aquél «se hizo en un concilio universal» [ = Niceno + Constantinopolitano], sólo válidamente «convocado por la autoridạd del Sumo Pontífice»; por lo demás, su redacción «pertenece a la misma autoridad, que debe determinar por sentencia las cosas de fe, para que sean inalterablemente mantenida por todos», lo que «pertenece a la autoridad del Sumo Pontífice» (Cf. Lc 22,33), por garantizar él «la unidad de la fe en toda la Iglesia»: Summa Theol., II-II, I 10. 
jo de un mundo..., en el que tantas verdades son completamente negadas o puestas en discusión»; pues si «la Iglesia juzga obligación suya no interrumpir los esfuerzos de penetrar más y más en los misterios profundos de Dios» así como de «proponerlos a los hombres de las épocas sucesivas cada día de un modo más apto», debe cuidar «que, mientras se realiza este necesario deber de investigación, no se derriben verdades de la doctrina cristiana» ${ }^{16}$; y seguidamente dio el Santo Padre «un testimonio firmísimo a la Verdad confiada a la Iglesia, para que la anuncie a las gentes», con la «Profesión de Fe» ${ }^{17}$, que «reúne los elementos esenciales de la fe católica» ${ }^{18}$ en una interpretación hodierna del Credo de Nicea y del Símbolo de los Apóstoles. De ahí su actualidad teológica.

Y no la perdió desde entonces. Pues, lamentablemente, no parecen haberse abierto todos los oídos de exégetas y teólogos sordos al Magisterio y, por ello, promotores de un pluralismo teológico frecuentemente herético ${ }^{19}$, en el que la unidad de la fe cristiana y de la dogmática de la Iglesia son sacrificadas sobre el altar de un liberalismo teológico y de un esnobismo mundano. El problema cobró tales dimensiones, que la Santa Sede decidió confiar su estudio y soluciones a la COMISIÓN PONTIFICIA INTERNACIONAL DE TEOLOGía, cuyos trabajos y deliberaciones fueron resumidos (a. 1972) en 15 tesis, - comentadas por algunos de sus más renombrados representantes ${ }^{20}$-, en cuyos análisis así como en otros estudios se percibe el esfuerzo por un equilibrio entre el justificado pluralismo teológico y la necesaria unidad dogmática ${ }^{21}$.

Ahora bien, ese equilibrio sólo es realizable, - nos parece-, si tanto el análisis exegético como la reflexión teológica se enraizan o vuelven a enraizarse en el fecundo subsuelo del Símbolo, aceptando como punto de partida esa unitaria Confesión de Fe cristiana ${ }^{22}$ y síntesis de la dogmática de la Iglesia, que la exégesis y la teología deben sin duda reinterpretar incesantemente para el hombre de su tiempo. Lo que significa: Si en curso del Cristianismo el Credo fue criterio seguro de la ortodoxia cristiana, es decir, faro de la exégesis y

16. Pablo VI, o.c., 4. 17. Pablo VI, o.c., 8-30. 18. Así lo designó Juan Pablo II, Exh. Apost. CT, 28. 19. Cf. K. Rahner, Häresien in der Kirche?: «Schriften zur Theologie», IX, Einsiedeln 1970, 453-478. 20. Cf. Comisión. Teológica Internacional, El pluralismo teológico, Madrid 1976, 11-104. 21. Cf. J. Ratzinger, Las dimensiones del problema: Ib. 15-50; Id., Sobre la cuestión de la validez permanente de las fórmulas dogmáticas; Ib., 61-68; B. Rigaux, Unidad y pluralidad de las imágenes de Jesús en Los Sinópticos: Ib., 107-148; Ph. Delhaye, Unidad de fe y pluralismo teológico según los documentos del Magisterio romano de los diez últimos años (1962-72): Ib., 149-175; L. Bouyer, La unidad de fe y el pluralismo teológico: Ib., 177-193. Sobre el justificado pluralismo teológico. Cf. también K. Rahner, Der Pluralismus in der Theologie und die Einheit des Bekenntnisses in der Kirche: o.c., IX 11-33; Id., El pluralismo en teología y la unidad de confesión en la Iglesia: Conc 46 (1969) 427-48; G. Philips, A propos du pluralisme en théologie: EThL 46 (1970) 149-79; M. Flick, Pluralismo teologico e unità della fede: Civ Catt 1 (1970) 323-33; R. Latourelle, Cristo y la Iglesia signos de salvación, Salamanca 1971, 165-71. 22. Cf. K. Rahner, Häresien in der Kirche?, 464-69; H. de Lubac, o.c., 346s. 
teología así como «la norma de fe» usada por el Magisterio de la Iglesia en la determinación y definición de sus verdades dogmáticas, también hoy el Símbolo está llamado a ser el árbitro de la ortodoxia exegética y teológica: El insustituible garante de ese equilibrio -difícil pero no menos necesario-entre pluralismo teológico y unidad dogmática, que necesita y está exigiendo la hodierna exégesis y teología de la Iglesia. De ahí la fraterna exhortación a mis colegas, exégetas y teólogos: ¡No olvidemos el Símbolo! Pues éste tiene además una indiscutible:

\section{Actualidad ecuménica}

«Promover la unidad entre todos los cristianos» fue «uno de los principales propósitos del Concilio Vaticano II», cuyo Decreto sobre el Ecumenismo, elaborado en la convicción de que la «división» entre las diversas Iglesias cristianas «contradice abiertamente a la voluntad de Cristo, es un escándalo para el mundo y daña a la sacratísima causa de la predicación del evangelio a todos los hombres» ${ }^{23}$, ha delineado los principios fundamentales, que deben guiar e impulsar a los fieles católicos en la práctica de un objetivo diálogo ecuménico ${ }^{24}$. Precisamente en la sincera y valiente realización de este diálogo, debe ocupar un puesto central el Símbolo de la Fe. Por varias razones:

1) El Símbolo ha sido y es tenido en alto aprecio por todos los Hermanos separados, como síntesis y expresión perenne de la fe apostólica ${ }^{25}$. En efecto, las separadas Iglesias ortodoxas consideran al Símbolo niceno-constantinopolitano «la suma de las decisiones dogmáticas de los 7 sínodos ecuméni$\cos$ (a. 325-787)» antiguos ${ }^{26} \mathrm{y}$, por tanto, «infalible norma de fe» ${ }^{27}$. Una valoración plenamente condividida por la Iglesia católica: ;El Credo nos mantiene unidos! También nos une con las Iglesias protestantes. Ya LUTERO lo comentó (a. 1529) en su «Catecismo mayor» y «menor» ${ }^{28}$, designándole acertadamente - como lo habían hecho varios Padres y lo haría después el Catecismo romano- «la suma» de la $\mathrm{fe}^{29}$. También J.CALVINo comentó amplia-

23. Conc. Vat. II, Decr. UR, 1. 24. Cf. Ibd., 2-23. 25. Cf. a este respecto: B. Lohse, Bekenntnisse. IV. Theologiegeschichtlich; RGG I 993s; W. Jannasch, Bekenntnis. Praktischtheologisch: Ib., 1000-3:1001s; W. Maurer, Bekenntnis. Rechtlich: Ib., 1003-7:1005ss; H. Lahr, Bekenntnisbildung: Ib., 1009-11:1010s; E. Wolf, Bekenntnisschriften: Ib., 1012-17:1012.1015s; J. Koenen, Anglikanische Artikel: LThK, I 545s; Y.M.-J. Congar, Anglikanische Kirche, II. Lehre: Ib., 548-52:548s; B. Schultze, Bekenntnisschriften. II. B. der Orthodoxen: Ib., 148s; W. Lohff, Bekenntnisse. IV.Protestantische B.: Ib., II 149-52:149s; P. Meinhold, Ökumenische Kirchenkunde, Stuttgart 1962, 101-102; W.D. Hauschild, a.c., 45-48; J.N.D. Kelly, o.c., 368 (trad. españ., 435s). 26. E. Wolf, a.c., 1015. 27. B. Schultze, a.c., 148. 28. Cf. M. Lutero, Der grosse Katechismus: "Luthers Werke», XXX. 1, Weimar 1910, 123-238: 182-92; Id., Der kleine Katechismus: Ib., 239-345:292-98. 29. Id., Der grosse Katechismus: o.c., 192; Cf. supra, 5. n. 13. A este propósito es instructivo recordar, que los Símbolos apostólicos, niceno y constantinopolitano fueron designados por Lutero «Símbolos ecuménicos»: E. Wolf, a.c., 1012; W. Lohff, a.c., 149. Todo ello muestra, que el padre de la reforma protestante «apreció en gran medida el Símbolo»: A. Harnack, Das Apostolische Glaubensbekenntnis, Berlin 1892, 17. 
mente el Símbolo, subrayando su origen apostólico - sin abordar el problema de su autor - y valorándolo como «el sumario de la fe» ${ }^{30}$. Nada de extraño, pues, si la CONFESIÓN AUGUSTANA (a. 1530) reasumió en su art. 1 el Símbolo niceno ${ }^{31}$, ampliamente comentado por dos renombrados TEÓlOGOS de la naciente reforma protestante ${ }^{32}$. La cual, por lo demás, no dudó en introducir aquél u otros Símbolos en su LITURGIA bautismal y eucarística ${ }^{33}$, cuyos fieles por tanto - como los de la Iglesia católica (Cf. infra) - son educados a la fe cristiana y la nutren con el Credo: ;El Símbolo nos une! Y nos vincula asimismo con los Hermanos anglicanos: De los 39 «artículos anglicanos» (a. 1571), el $8 .^{\circ}$ «reconoce los tres. Credos de la Iglesia como contenidos en la Escritura» ${ }^{34}$, siendo considerado el Credo niceno como «la autorizada interpretación» del Símbolo bautismal ${ }^{35}$; nada de extraño, pues, si el Credo forma parte de su liturgia bautismal y eucarística: ;Un sólido lazo de unión con los fieles católicos!

Y a consolidar ese lazo han contribuido sensiblemente, por lo demás, la investigación histórica y la reflexión teológica realizada en los dos últimos siglos por especialistas y miembros de las diversas confesiones cristianas, separadas de la Iglesia católica. En efecto, la moderna investigación del Símbolo debe muchísimo a las aportaciones - frecuentemente decisivas - de sus varios e ilustres exégetas e historiadores del cristianismo antiguo (C.P. Caspari y A. Hahn, A. Harnack y Th. Zahn, F. Kattenbusch, H. Lietzmann y J.N.D. Kelly...). Y a su valoración teológica dio un nuevo impulso el mayor teólogo protestante -K. Barth- de nuestro siglo, comentando el Credo ${ }^{36}$ y explicando a raíz de sus doce artículos «los principales problemas de la Dogmática», en la convicción de que ésta es «la explicación del Símbolo» ${ }^{37}$. A otro renombrado teólogo hodierno debemos asimismo una detenida explicación del Símbolo apostólico, en un intento por interpretar su contenido para el hombre de nuestro tiempo ${ }^{38}$.

30. J. Calvino, Symboli explicatio: «Christianae Religionis Institutio», cap. VI-VIII («Corpus Reformatorum», XXIX, Brunschwig 1863, 478-686): El Símbolo es de origen apostólico (o.c., VI 3: "Corpus...», XXIX 478) y, en su división trinitaria, contiene «todo el misterio de nuestra redención» (o.c., VI 5: «Corpus...», XXIX 479), siendo el sumario de la fe» (Institution de la Réligion Chepetienne [Genève 1955], II, XVI 5). 31. Cf. W. Maurer, a.c., 1005. A este respecto, 'Cf. también W.D. Hauschild, a.c., 47s; Id., Die Confessio Augustana und die altkirchliche Tradition: KuD 26 (1980) 142-63. Sobre la «Confesión Augustana», en general, Cf.: H. Bornkamm, Augsburger Bekenntnis: RGG, I 733-36 (bibliogr.); Th. Sartory, Augsburger Konfession, en: LThK I 1079-81 (bibliogr.). 32. Cf.: C. Cruciger, Enarratio Symboli Niceni (a. 1550): «Corpus Reformatorum», XXIII, Brunschiwig 1855, 209-246 (instructivo prefacio de PH. Melanchton, Ib., 196-209); P. M. Melanchton, Explicatio Symboli Niceni (a. 1557): Ib., 347548. 33. Cf. W. Jannasch, a.c., 1001s; W. Maurer, a.c., 1006s; H. Lahr, a.c., 1010.34. J. Koenen, a.c., 546. 35. Y.M. J. Congar, a.c., 548. 36. Cf. K. Barth, La Confession de foi de l'Église. Explication du Symbole des Apôtres d'après le Catéchisme de Calvin. Neuchâtel 1943, ( ${ }^{2} 1946$; Id., Dogmatik im Grundriss, Zürich (1947) ${ }^{4} 1977,16-182 . \quad$ 37. Id., Credo. Die Hauptproblemen der Dogmatik dargestellt an Anschluss an das Apostolische Glaubensbekenntnis, Zollikon-Zürich 1946, 11; Id., Dogmatik..., 9-182:15. 38. W. Pannenberg, Das Glau- 
Es, pues, normal que, en el hodierno esfuerzo «por la base común de la fe y de la predicación», las iglesias separadas «busquen determinar su relación con las confesiones de fe de los padres» de la reforma, para «la solución de cuya tarea» importa "reconquistar la interna unidad de las motivaciones de la Confesión [de $\mathrm{Fe}$ ], proveniente de la Iglesia primitiva...» ${ }^{39}$. Esta reconquista reclama y exige también el diálogo ecuménico. Así lo entendió el CONSEJO ECUMÉNICO DE LAS IGLESIAS, haciendo del Símbolo niceno-constantinopolitano el fundamento de su fórmula básica ${ }^{40}$.

2) Los precedentes desarrollos, - que podrían ampliarse-, muestran claramente el puesto de honor reservado al Símbolo de la Fe por la teología y piedad de todos los Hermanos separados, del todo similar al que ocupó y ocupa en la teología y piedad de la Iglesia católica. No es, por tanto, exagerado afirmar, que el Credo apostólico o la Confesión de Fe en el Dios Uno y Trino así como en el misterio redentor del Hijo de Dios encarnado es el más fuerte lazo de unión entre todos los hermanos separados, que aún liga estrechamente a la cristiandad dividida: ;El más sólido tejido, que aún mantiene unida «la inconsútil túnica» de Cristo! (Jn 19,23b). En efecto, puesto que «los antiguos Credos cristianos constituyen aún por sí un lazo de unidor» entre las iglesias separadas, «la Confesión de $\mathrm{Fe}$ es... también el distintivo por el que las iglesias son reconocidas en su unidad de fe» ${ }^{41}$, de forma que al recitar el Credo «nos sentimos uno con todos los cristianos» ${ }^{42}$. Si, pues, en su ya inaugurado diálogo con los hermanos separados debe la Iglesia católica «poner de relieve sobre todo lo que nos es común, antes de subrayar lo que nos divide» ${ }^{43}$, no sería exagerado afirmar que ese acento tiene que recaer ante todo y principalmente en el Símbolo: ‘En el común Credo apostólico, niceno y constantinopolitano debe centrarse todo el esfuerzo de la hodierna tarea ecuménica! Esto, precisamente, refleja la cálida exhortación del Magisterio conciliar, cuando pide que «todos los cristianos profesen ante todas las gentes la fe en Dios Uno y Trino, en el Hijo de Dios encarnado, Redentor y Señor nuestro» ${ }^{44}$ : ¡Alusión evidente al Símbolo de la Fe! Una no menor clara alusión envuelve también la enseñanza del mismo Magisterio conciliar, afirmando que «la acción ecuménica de los fieles [católicos] tiene que ser plena y sinceramente católica, es decir, fiel a la verdad que recibimos de los Apóstoles y de los Padres, y conforme a la

\footnotetext{
bensbekenntnis ausgelegt und verantwortet vor den Fragen der Gegenwart, Hamburg 1972; trad. españ.: La Fe de los Apóstoles, Salamanca 1975 (citamos sólo según esta traducción). Instructivos, a este respecto, son también los sermones sobre el Símbolo del teólogo protestante H. Tielicke, Ich glaube. Das Bekenntnis der Christen, Freiburg 1971. 39. H. Lahr, a.c., 1010s. 40. Cf. H.L. Althaus, Ökumenische Dokumente, Göttingen 1962, 11s. 41. P. Meinhold, o.c., 101.102; Cf. también a este respecto W. Beinert, o.c., 14s. 42. W. Pannenberg, o.c., 26. Un acceso a la comprensión ecuménica del Símbolo de la Fe ofrecen W. Beinert-K. Hoffmann-H. von Schade, Glaubensbekenntnis und Gotteslob, Einsiedeln-Zürich 1971; Cf: también H. Schröer, Unser Glaubensbekenntnis heute. Versuch einer theologischen Bilanz, Hamburg 1971, 52-85. 43. Pablo VI, Enc. ES $102 . \quad$ 44. Conc. Vat. II, Decr. UR 12.
} 
fe siempre profesada por la Iglesia católica» ${ }^{45}$ : Nadie duda, que «la verdad» recibida por la Iglesia «de los Apóstoles y de los Padres», y por ella «siempre profesada», está precisamente sintetizada en el Credo, «compendio de la fe» cristiana y «síntesis de la dogmática de la Iglesia» ${ }^{46}$; en este sentido, «la acción ecuménica de los fieles» católicos debe enraizarse en el Símbolo, que fue y es - como decíamos - el lazo y tejido de unión entre todos los creyentes en Cristo. ¡Un lazo en verdad extrecho y un tejido del todo consistente! Pues si el Símbolo, además de compendiar la fe de la Iglesia y sintetizar su teología es también «el eje del cristianismo» así como «la espina dorsal del cristiano» ${ }^{47}$, en realidad nos une a todos los cristianos mucho más de lo que nos separa: ¡Nos une un mismo compendio de fe y una misma síntesis dogmática! ¡Tenemos un mismo eje así como una misma espina dorsal! ¡Sólo nos separan las vértebras de algunas verdades dogmáticas! ¿Hemos cobrado suficientemente conciencia de esto? ¿No hemos olvidado con frecuencia este elemental presupuesto del ecumenismo cristiano? ¿No se centra frecuentemente nuestro diálogo en verdades teológicas ciertamente sustanciales, pero no explícitamente profesadas en el Credo común? ;Vuelta al Símbolo! .

3) A la escasa importancia dada hasta el presente al Credo común se debe, probablemente, la triste constatación de K. Rahner, según el cual «el resultado» del hodierno diálogo ecuménico «entre teólogos de diversas confesiones cristianas es muy pequeño» ${ }^{48}$. Lo que no debe descorazonarnos. ¡Al contrario! Pues, por otra parte, desde que fue formulada esa constatación ha experimentado notables avances el interconfesional diálogo y colaboración entre exégetas ${ }^{49}$ y teólogos ${ }^{50}$. Un claro indicio de ese progreso es la reciente obra de

45. Conc. Vat. II, Decr. UR 24. 46. Cf. supra, 4-7. 47. Cf. supra, 8s. 48. K. Rahner, Einige Probleme der Ökumenismus heute, en: «Schriften zur Theologie», X, Einsiedeln 1972, 493-502:494. 49. Reflejo de esta colaboración es la Traduction oecuménique de la Bible, Paris 1977 (con anotaciones interconfesionales); Cf. también: La Biblia Interconfesional. Nuevo Testamento. Madrid (BAC) 1978; Evangelisch-Katholischer Kommentar zum Neuen Testament, Hrsg, von J. Blank-R. Schnackenburg (catól.) y E. Schweizer-Uwilckens (Protest.), NeukirchenZürich, Einsiedeln-Köln 1975ss: Han sido publicados ya los comentarios a Flm (a. 1975: P. Stuhlmacher), $C o l$ (a. 1976: E. Schweizer), $M c$ (a. 1978-79: J. Gnilka), $R m$ (a. 1978-82: U. Wilckens) y Ef (a. 1982: R. Schnackenburg). A este respecto, Cf. O. Cullmann, Biblia en el diálogo interconfesional (trad. españ.), Salamanca 1968. 50. Cf. a este respecto: K. Schuh (Hrsg.), Amt im Widerstreit, Berlin 1973; AA.VV., Reform und Anerkennung kirchlichen Ämter, MünchenMainz 1973; H. Meyer, Luthertum und Katholizismus im Gespräch, Frankfurt 1973; K. Rahner, Vorfragen zu einem ökumenischen Amtsverständnis, Freiburg 1974; H. Stirnimann-L. Vischer (Hrsg.), Papstum und Petrusdienst, Frankfurt 1975; Comisión Católica-Luterana, Das Herrenmahl, Paderborn-Frankfurt 1978; P. Lengsfeld-H.G. Stobbe, Theologischer Konsenz und Kirchenspaltung, Stuttgart-Berlin 1981; Comisión Anglicana-Católica, Declaración de Windsor (a. 1981): HerderKorr 36 (1982) 288-93; H. Fries, Das Petrusamt im anglikanisch-katholischen Dialog: StimZeit 200 (1982) 723-38; P. Gordan (Hrsg.), Die Kirche Jesuchristi. Enttäuschung und Hoffnung, Graz 1982; J. Ratzinger, Theologische Prinzipienlehre, München 1982, 265-281; K. Lehmann-W. Pannenberg (Hrsg.), Glaubensbenntnis und Kirchengemeinschaft, FreiburgGöttingen 1982. Del todo alentador, à este respecto, es el comentario ecuménico al Credo por va- 
dos teólogos católicos, -el mismo K. Rahner y H. Fries-, en la que «la unión de las Iglesias» es valorada no sólo posible sino, más exactamente, como una "posibilidad real» ${ }^{51}$ : Por ellos concretizada ésta en la formulación de ocho tesis ${ }^{52}$, - cada una de ellas ampliamente comentada - ${ }^{53}$, que deberían ser aceptadas por todas «las iglesias particulares» y llamadas con ello a unirse en «una Iglesia universal», bajo la guía «del Papa romano» en cuanto «garante concreto de la unidad de la Iglesia en la verdad y el amor» ${ }^{54}$. No es de nuestra competencia - tampoco interesa aquí- valorar la objetividad de esta propuesta ecuménica, que por la cualidad de sus autores debe -en todo casoser tomada muy en serio. Lo que sí es del todo sintomático, a nuestro propósito, es el hecho de que la primera de esas tesis o postulados de la «realmente posible» unión reza: «Las verdades fundamentales del cristianismo, tal como están expresadas en la Sagrada Escritura, en los Credos apostólicos, niceno y constantinopolitano, son normativas para todas las Iglesias particulares de la futura Iglesia única» ${ }^{55}$. Los dos autores - de indiscutible talla teológica y empeño ecuménico - condicionan, pues, la «posibilidad real» de la «unión de las Iglesias» ante todo a la común aceptación de las «fundamentales verdades» cristianas, «expresadas» tanto «en la Sagrada Escritura» como «en los Cre$d o s »$ primitivos de la Iglesia. Este último aspecto subraya el respectivo comentario de H. Fries ${ }^{56}$, precisando que si «el Símbolo apostólico y su contenido pertenece al fundamento de las Iglesias cristianas de occidente» ${ }^{57}$, el Credo niceno y constantinopolitano - altamente apreciado éste, tanto por las iglesias orientales como por las Iglesias reformadas de occidente- ${ }^{58}$ "es una grapa que aun hoy mantiene unidas a las Iglesias cristianas separadas y; a la vez, exige la unidad de» aquéllas, pues «la permanente validez de» estos dos Símbolos «es la garantía de la continuidad e identidad de las Iglesias a través del tiempo» ${ }^{59}$.

Como garante de identidad cristiana y grapa unidora de todos los creyentes en Cristo, el Credo está llamado, por tanto, en la actualidad a jugar un papel determinante - ciertamente central- en el último esfuerzo, porque la

rios teólogos y exégetas de directas confesiones cristianas: G. Rein (Hrsg.), Das Glaubensbekenntnis, Stuttgart 1967 (trad. ital. Brescia 1971). 51. Cf. K. Rahner-H. Fries, Einigung der Kirchen-Reale Möglichkeit (QD 100), Freiburg 1983: En su introducción (9-15) afirman ambos autores, que la «unidad de la Iglesia», objeto del «precepto del Señor» y «cuestión de vida y muerte para la Cristiandad» en la hora actual, no sólo es del todo necesaria sino que «hoy es real mente posible»: 14. 52. O.c., 17-19. 53. O.c., 23-156. 54. H. Fries, o.c., 70-97. 55. O.c., 17.25. 56. O.c., 23-34:25-31. 57. Id., o.c., 27. De ahí que ya en el a. 1967 todas las Iglesias cristianas de Alemania hicieron una traducción común del Símbolo: ¡Es de esperar, que tal iniciativa ecuménica se universalice pronto! 58. Cf. Id., o.c., 28-29. 59. Id. o.c., 28.30. La verdadera dificultad, a este respecto, reside en que la unidad de la común Confesión de Fe está quebrada por la diversa interpretación de algunos de sus artículos centrales, sobre la cual el católico debe atenerse naturalmente al Magisterio de la Iglesia, al que «únicamente fue confiado el oficio e interpretar auténticamente la Palabra de Dios oral o escrita»: Conc. Vat. II, Const. DV 10; Cf. Decr. UR 21. 
«posibilidad real» de la unión anhelada devenga pronto realidad lograda. Pues sólo cuando los creyentes en «un solo Dios y Padre» así como en «un solo Señor» y en «un solo Espíritu» (Ef 4, 3-6) centren todo su esfuerzo en el estudio y, sobre todo, la vivencia del Símbolo o confesión común de «una sola fe» $(\mathrm{Ef} 4,5)$, podremos llegar «todos a la unidad de la fe» en Cristo (Ef 4,13). De ahí mi cálida exhortación a todos los ecumenistas y, en general, a todos los cristianos sensibles al diálogo ecuménico: ¡No olvidemos el Símbolo!

\section{Actualidad catequética}

No deben olvidarlo, sobre todo, el «pastor» y el catequista en su ardua pero no menos necesaria labor catequética, la cual, si «ha sido siempre para la Iglesia un deber sagrado y un derecho imprescindible», constituye hoy «una tarea absolutamente primordial de su misión» ${ }^{60}$ evangelizadora y catequética. Ahora bien, el Símbolo de la Fe debería ocupar precisamente un puesto de singular relieve, en la hodierna tarea catequética de la Iglesia. Y esto, a todos los niveles:

1) No hay duda alguna, que la catequesis pre-bautismal tiene que centrarse ante todo en el Credo. Así lo hizo desde antiguo la Iglesia. Y maestros consumados, al respecto, son ciertamente los grandes catequistas de la antigüedad cristiana (san Cirilo Jer. y Nicetas de Remesiana, Teodoro M. y san Agustín, san Quodvultdeus y san Pedro Crisólogo, san Máximo de Turín y san Ildefonso de Toledo...), quienes instruyeron a los catecúmenos en la fe sobre todo comentando el Símbolo (Cf. infra), legándonos así esa rica literatura catequética sobre el Credo, que constituye uno de los más preciados tesoros heredados por la Iglesia de la edad patrística ${ }^{61}$. iEn aquella literatura tendría que instruirse y de ella debería servirse con frecuencia el catequista hodierno! No sólo para seguir así, de cerca, las huellas de sus ilustres antepasados, aprendiendo de ellos tanto la pedagogía catequética como - y sobre todo- el rico venero teológico del Símbolo. El contacto asiduo con los comentarios patrísticos al Símbolo se impone hoy con particular apremio al catequista, para responder a la exigencia del Magisterio hodierno sobre la restauración del «catecumenado de adultos» ${ }^{62}$, cuidando los Pastores que «se restablezca o se adapte mejor la instrucción de los catecúmenos adultos» ${ }^{63}$ y que éstos no sólo «se inicien convenientemente en el misterio de la salvación» sino también «sean introducidos en la vida de fe» ${ }^{64}$ : „Ninguna mejor instrucción catecumenal, ninguna más conveniente iniciación al misterio salvífico, ninguna mejor introducción a la vida de fe que la catequética explicación del Símbolo! Y esa instrucción catequética alcanza, en la actualidad, un punto culminante en los

60. Juan Pablo II, Exh. Apost. CT, 15.16. 61. Cf. infra, 54ss. Const. GS 64.66; Cf. Decr. AG 14. 63. Conc. Vat. II, Decr. ChD 14. Decr. AG 14.
62. Conc. Vat. II, 64. Conc. Vat. II, 
ritos de la «entrega» y «devolución del Símbolo», mediante los cuales la Iglesia - con amor materno- consigna a los catecúmenos el compendio de su fe [«entrega del Símbolo»], para que públicamente la confiesen [= «devolución del Símbolo»] o atestigüen ${ }^{65}$. El Símbolo de la fe debe ser, pues, hoy-como en la edad patrística fue- la espina dorsal de la catequética instrucción catecumenal.

2) También la catequesis post-bautismal debería centrarse en el Credo. Así lo enseña el hodierno Magisterio, asegurando que tanto los antiguos Símbolos o «síntesis felices de la fe de la Iglesia» como «el Credo del Pueblo de Dios» de Pablo VI son una «referencia segura para el contenido de la catequesis» post-bautismal ${ }^{66}$. Ésta, por tanto, debe nutrirse del Símbolo:

a) Ya la catequesis para niños, adolescentes y jóvenes. En efecto, los niños que se preparan a la primera comunión o a la eucarística celebración del Misterio Pascual, en el que participaron ya por el bautismo, deben por ello cobrar conciencia sobre todo de su fe bautismal: Revivir el triple «creo», con el que -en nombre suyo- respondieron sus padrinos a la triple pregunta del Símbolo bautismal, que les hizo la Iglesia sobre la fe «en Dios Padre» y «en su Hijo Jesucristo» y «en el Espíritu Santo». ;Una adecuada catequesis sobre el Credo es, pues, sin duda alguna, la mejor preparación a esa post-bautismal revivencia del Símbolo! Aquella renovación de las promesas bautismales deberán hacer también los adolescentes y jóvenes, antes de recibir el sacramento de la confirmación: Su ritual hodierno, - renovado «para que aparezca más claramente» la «íntima relación» de ese sacramento con el bautismo- ${ }^{67}$, exige de aquéllos la renovación del triple «sí, creo» bautismal, para recibir luego el don del Espíritu Santo - mediante la imposición de las manos- y ser fortalecidos para el combate cristiano con la sagrada crismación ${ }^{68}$. La catequesis pre-confirmacional debería iniciar, por tanto, con una apropiada instrucción - más profunda que la anterior-sobre cada artículo del Credo, robusteciendo así la vida espiritual de los confirmandos con el vigor del Símbolo o «la espina dorsal del cristiano» (Cf. supra) y para sostener victoriosamente su futura «lucha» contra «el maligno» (Cf. Ef 6,12), proporcionándoles con ello la segura defensa del Credo o «el escudo de la fe» (Cf. supra).

Urge, pues, impregnar de aquél los catecismos para niños, adolescentes y jóvenes, elaborándolos según la estructura trinitaria del Símbolo de la Fe, con

65. Cf. S. Congregación del Culto, Rituale Romanum. Ordo initiationis christianae adultorum, Ciudad del Vaticano 1972, Nos 183-87.194-99. 66. Juan Pablo II, Exh. Apost. CT 28. De modo análogo se expresaba un ilustre patrólogo y teólogo, afirmando que «la Profesión de fe de Pablo VI... debe ser la norma de toda catequesis y de toda evangelización» (J. Card. Daniélou, Iglesia y secularización (J. Daniélou-C. Pozo), Madrid 21973, 45), por constituir «la carta magna de los apóstoles, transmitida y explicada por la Iglesia infalible... a los hombres de nuestro tiempo»: Id., ¿Desacralización o evangelización? Bilbao 1969, 46. 67. Conc. Vat. II, Const. SC 71; Cf. S. Congregación del Culto, Pontificale Romanum. Ordo Confirmationis, Ciudad del Vaticano 1973, Nos 1-3.5. 68. O.c., Nos 35.40 . 
el fin de iniciar a aquéllos en las sólidas verdades centrales del cristianismo, y conferir a éstos una fe adulta que resista victoriosamente «las pruebas»: Todo ello, a raíz de una esmerada y cuidadosamente adaptada explicación de sus doce artículos ${ }^{69}$. Una tarea, hoy, particularmente necesaria. Pues esa instrucción catequética es precisamente el mejor modo de contrarrestar el influjo de hodiernas publicaciones catequéticas «equívocas y perjudiciales para los jóvenes y para la vida de la Iglesia», por «desorientar a los jóvenes y aún a los adultos ya por la omisión - consciente o inconsciente - de elementos esenciales a la fe de la Iglesia, ya por la excesiva importancia dada a determinados temas con detrimento de los demás, ya sobre todo por una visión global harto horizontalista, no conforme con la enseñanza del Magisterio de la Iglesia», debiendo por tanto «las obras catequéticas» - entre otras cosas- «decir todo el mensaje de Cristo y de su Iglesia, sin pasar por alto ni deformar nada, exponiéndolo todo según un eje y una estructura, que hagan resaltar lo esencial» ${ }^{70}$. iA todas estas exigencias del Magisterio supremo sobre la cualidad de la instrucción catequética responde precisamente el Símbolo, cuyo «eje y estructura» resalta «lo esencial» de la fe cristiana, por compendiar «todo el mensaje de Cristo» y sintetizar los «elementos esenciales a la fe de la Iglesia»! La post-bautismal catequesis sobre el Credo es pues necesaria y, más aún, apremiante. Lo es ciertamente, si se tiene en cuenta, por lo demás, el grande -a veces determinante- influjo, que sobre niños, adolescentes y jóvenes ejercen hoy tanto maestros no cristianos como algunos medios de comunicación, - ¡la televisión y el cine!-, en los que frecuentemente se propagan y defienden ideologías secularizantes, inmorales e incluso abiertamente anticristianas. Es, por tanto, del todo necesario rearmar espiritualmente a aquéllos, mediante una sólida instrucción sobre las verdades basilares de nuestra fe: ¡Éstas contiene y sintetiza precisamente el Símbolo! De ahí que, como subraya con acierto un hodierno comentarista protestante del Credo, «hoy se debería conceder una especial atención en las iglesias a la interpretación y explicación de los enunciados de la profesión de Fe» ${ }^{71}$. Lo que significa: Hoy como ayer sigue siendo el Símbolo de la Iglesia la «gran defensa» del cristiano, su «coraza

69. Un buen ejemplo, al respecto, es la «Explicación del Símbolo apostólico» del mayor teólogo medieval (St. Tomás A., In Symbolum Apostolorum expositio, en: «Opuscula Theologica», II [ed. R.M. Spiazzi], Roma 1954, 193-217), quien expone incluso la doctrina sobre la gracia y los sacramentos en el contexto del artículo sobre «la comunión de los santos» (O.C., 213s). Un ilustre liturgista católico de nuestro siglo aconseja seguir este ejemplo en la estructuración global del catecismo, iniciando con la doctrina sobre la fe en Dios y en el misterio redentor de Cristo, -iéste en el centro! - , para proseguir con la de la Iglesia, en cuyo contexto se debería exponer la teología sobre la gracia y los sacramentos: Cf. J.A. Jungmann, Katechetik. Aufgabe und Methode der religiösen Unterweisung, Freiburg ${ }^{3} 1965$, 97-100. Lamentablemente son hoy poquísimos los catecismos así redactados y estructurados, siendo excelentes excepciones los elaborados por: A. BaurW. Plöger, Botschaft des Glaubens, Donauwörth-Essen, 1978; Obispos Alemanes, Katholischer erwachsenen Kathechismus. Das Glaubensbekenntnis der Kirche, München-Stuttgart 1985. 70. Juan Pablo II, Exh. Apost. CT 49. 71. W. Pannenberg, o.c., 27. 
contra» las seducciones del mundo y su «remedio contra el veneno de la serpiente» diabólica, «el escudo de su fe» ${ }^{71 a}$.

b) No menor actualidad e importancia tiene hoy el Credo de la Iglesia en la catequesis para adultos. También a ésta, en efecto, se refiere JUAN PABLO II, cuando enseña que tanto los «antiguos Símbolos» como «el Credo» de Pablo VI son «una referencia segura para el contenido de la catequesis» (Cf. supra). Pero, ¿cómo introducir y estructurar en las parroquias esa catequesis permanente para adultos? Este interrogante plantea, sin duda, uno de los más urgentes problemas de la pastoral catequética hodierna. La solución, por lo demás, ha sido reiteradamente insinuada por el actual Magisterio supremo: Ya PABLO VI aseguró, que «las condiciones actuales hacen cada día más urgente la enseñanza catequética bajo la modalidad de un catecumenado, para un gran número de jóvenes y adultos que, tocados por la gracia, descubren poco a poco la figura de Cristo y sienten la necesidad de entregarse a Él» ${ }^{72}$; JUAN PABLO II re-asumió y prolongó esta enseñanza, en el contexto de su instrucción sobre la catequesis para adultos ${ }^{73}$, afirmando que ésta — «la forma principal de la catequesis»- hoy «ha de ser permanente, para que sea eficaz» ${ }^{74}$, no sin precisar seguidamente la necesidad que tienen de ser reiniciados a una fe adulta quienes, por diversas circunstancias, fueron insuficientemente o «nunca educados en su fe y, en cuanto adultos, son verdaderos catecúmenos» ${ }^{75}$. El actual Magisterio supremo invita, pues, a estructurar «bajo la forma de un catecumenado» la «catequesis permanente» para aquellos adultos, que la necesitan por ser «verdaderos catecúmenos» o - reservando este vocablo (según su significado prístino) a los aún no bautizadosneocatecúmenos.

3) A esa exigencia del Magisterio responde precisamente el «CAMINO NEOCATECUMENAL» ${ }^{76}$, -la más sólida experiencia hodierna de iniciación a la fe cristiana para jóvenes y adultos-, cuya fase catequética alcanza ciertamente una de sus más encumbradas cimas en el período bienal de la «entrega» y «devolución del Símbolo»:

a) Ese período, en efecto, se inaugura con el rito de la entrega del Símbolo», en el que los neocatecúmenos reviven esa parte de su bautismo. Cuidadosa y eficientemente preparados aquéllos con una convivencia de tres días, - dirigida por los catequistas de la(s) comunidad(es) respectiva(s) - , la consignación del Credo tiene lugar luego durante un rito solemne y ciertamente

71a) Cf. supra, 9s. 72. Pablo VI, Exh. Apost. EN 44. 73. Cf. Juan Pablo II, Exh. Apost. CT 43-44. 74. Id., o.c., 43. 75. Id., o.c., 44. 76. Iniciado en Madrid (a. 1967) por iniciativa de los jóvenes españoles Francisco Argüello y Carmen Hernández, seguidamente introducido en Roma (a. 1968) y extendido actualmente por más de 74 naciones de los cinco continentes, es hoy -en nuestra opinión- la más válida - ya sólida y fructíferamente experimentada - respuesta concreta a ese requerimiento del Magisterio. Una objetiva información general, al respecto, ofrece G. Zevini, Neocatecumenato: NDSp (Roma 1982), 1057-73 (bibliogr.). 
sugestivo, presidido por el obispo: Una breve monición ambiental sobre el significado del rito, seguida del adecuado canto, preceden al introductor saludo del Presidente, al que sigue la proclamación de las dos primeras Lecturas bíblicas sobre la misión de Moisés (Ex 3,1-22) y sobre el kerygma post-pascual de los primeros Enviados (1Cor 15,1-11); tras esa doble proclamación de la Palabra, precedida y acompañada de respectivas moniciones y cantos, tiene lugar la recitación del Credo por el obispo y los presbíteros, como pública confesión y transmisión de la fe a los neocatecúmenos por la Iglesia, en aquéllos representada; una transmisión completada con la proclamación de la tercera Lectura bíblica sobre la necesidad de confesar «con la boca» la Palabra creída «en el corazón» (Rm 10,8-17), tras la cual interroga el obispo a la(s) comunidad(es) si acepta(n) el envío a confesar la $\mathrm{Fe}$ [=el Símbolo], que oficialmente la Iglesia les ha transmitido; al «sí» de aquélla(s) responde la proclamación del Evangelio sobre el primer envío de los doce por Jesús (Mt 10,7-10.1242), seguidamente comentado por el Presidente en su homilía; el rito se concluye con un exorcismo, -isólo liberados de quien "siembra la cizaña» es posible ir a sembrar el «buen grano»! - , pronunciado por el presbítero sobre cada neocatecúmeno, - ante aquél arrodillado-, al que siguen las oraciones y el canto final, con la conclusiva bendición del Presidente. En explícita referencia al rito de la «entrega del Símbolo», hoy re-introducido «en la iniciación de los catecúmenos», se interroga Juan Pablo II si «no habría que encontrar una utilización más concretamente adaptada, para señalar esa etapa -la más importante de todas - en la que un nuevo discípulo de Jesucristo acepta con plena lucidez y valentía el contenido de lo que más adelante va a profundizar con seriedad» ${ }^{77}$ : Una concreta y eficaz adaptación de la antigua «entrega del Símbolo» es ciertamente el respectivo rito del Camino neocatecumenal.

b) Este rito - decíamos - inaugura un período bienal, durante el cual la comunidad neocatecumenal debe vivir y confesar la previamente recibida $\mathrm{Fe}$ de la Iglesia:

- La experiencia personal del Símbolo en la propia historia es semanalmente incentivada por una celebración - comunitaria y doméstica- de la $\mathrm{Pa}$ labra sobre cada artículo del Credo, convenientemente preparada por un grupo a raíz de especializada bibliografía patrístico-teológica y, sobre todo, de adecuados textos bíblicos, para ofrecer seguidamente a la comunidad el tema -en una celebración presidida por el presbítero- con tres o cuatro Lecturas bíblicas, catequéticamente comentadas por uno del grupo preparatorio; los integrantes de éste ofrecen en esa ocasión a la comunidad un cuestionario práctico sobre el celebrado artículo del Credo, al que los miembros de aquélla deben responder - durante la semana - en celebraciones domésticas, cada una de ellas asistidas por uno del grupo preparatorio; éste prepara -en la tercera semana - una nueva celebración de la Palabra, en la que - a raíz de cuatro

77. Juan Pablo II, Exh. Apost. CT 28. 
Lecturas bíblicas proclamadas - intenta iluminar la problemática existencial suscitada por las previas respuestas al cuestionario. El respectivo artículo del Símbolo es así profundamente estudiado y solemnemente celebrado, contribuyendo eficazmente, tanto aquel estudio como esta celebración, a que su mensaje cale en la realidad existencial de la propia historia: «¿Hay un solo Dios en mi vida?»... «¿Creo realmente que Él me ha creado, todo lo hizo bien en mi historia y es mi Padre?»... «¿Puedo afirmar, que Jesucristo es el único Señor de mi existencia?»... «¿En qué medida descendió y desciende Él al infierno de mi vida?»... «¿Creo realmente que Él resucitó de entre los muertos y, por tanto, tiene poder sobre mi realidad de sufrimiento y de muerte?»... «¿Qué significa para mí hoy la fe en la Vida eterna?»... Así deviene gradualmente el Símbolo como algo personal, una fe vivida y encarnada en la historia de cada día, experimentada también a raíz de frecuentes crisis existenciales, absolutamente necesarias para madurar en la fe y con las que, asimismo, se aprecia tanto el gratuito don de aquella fe como la humanamente imposible tarea de llegar a ser un cristiano adulto: iSi el Señor no construye la casa, en vano se afanan los constructores!» (Sal 127,1).

-Adiestrados así los neocatecúmenos, con esa experiencia personal del Símbolo, durante ese período bienal deben también confesarlo a las gentes, anunciando a todos - con especial énfasis a quienes realmente no creen en Dios y en su Hijo Jesucristo- «lo que han visto y oído» ${ }^{78}$, es decir, dando personalmente «testimonio» de que «la Vida se manifestó y nosotros la hemos visto» ${ }^{79}$, pues «Dios es amor» $\mathrm{y}$ «nosotros hemos conocido el amor que Dios nos tiene» $(1 \mathrm{Jn} 4,16)$. Y puesto que, «además de la proclamación... colectiva del Evangelio», en la hodierna tarea evangelizadora «conserva toda su validez e importancia esa otra transmisión de persona a persona» ${ }^{80}$, el obispo o el párroco enviará a aquéllos «de dos en dos» ${ }^{81}$ por las casas, para, tras dirigirles a sus moradores «el saludo de la Paz» (Cf. Mt 10,12-13par), anunciarles seguidamente la Buena Nueva sobre «la cercanía del Reino de Dios» ${ }^{82}$ Padre así como sobre la muerte salvífica y la resurrección victoriosa de su Hijo Jesucristo ${ }^{83}$, por las que «nos reconcilió consigo» y ofrece gratuitamente -a

78. Cf. Mt 11,4-5 = Lc 7,22. Un análisis exegético sobre Mt 11,2-6=Lc 7,18-23 ofrecemos en nuestra monografía La embajada mesiánica de Juan Bautista, Madrid 1980, 3-202, en la que nos hemos esforzado por precisar el significado teológico de esos «signos» mesiánicos (Mt 11,5=Lc $7,22)$ al nivel histórico del mensaje de Jesús (o.c., 178-90), así como por ofrecer una hodiernización teológico-pastoral de esa importantísima perícopa evangélica: O.C., 205-262. 79. 1Jn 1,2; Cf. 5,5-12; Jn 1,32-34: 19,34-35; Act 4,33; 10,40-43; 8,23 etc. 80. Pablo VI, Exh. Apost. EN 46. 81. Como Jesús envió a sus discípulos (Cf. Mc $6,7=\mathrm{Lc} 10,1$ ) y como las Comunidades apostólicas enviaban a sus misioneros (Act 13,2-4; Cf. 3,1.11;4,13.19; 8,14; 13,43; 15,2.36-40; 16,35; 17,10): A este respecto, Cf. J. Jeremias, Paarweise Sendung im Neuen Testament: "Abba», Göttingen 1966, 132-39:135ss; Id., Theologie NT, 226 (trad. españ., 274s). 82. Mt $10,7=$ Lc 9,$2 ; 10,9 ;$ Cf. Act 8,$12 ; 19,8 ; 20,25 ; 28,23-31$. 83. Cf. Act 4,33; 10,38-42; 13,30-37; 2 Cor 4,5-12 etc. 
cuantos, creyendo en Él, se convierten- el perdón de los pecados ${ }^{84}$ y el aon de la Vida eterna ${ }^{85}$. Tras haber orado y escuchado la Palabra o empuñado «las armas de Dios» ${ }^{86}$, conscientes por lo demás de que «al ir, va llorando el que esparce la semilla» (Sal 126,6a), aquéllos van «tímidos y temblorosos» (1Cor 2,2) y, a la vez, «hablando con valentía sobre el Señor» Jesús ${ }^{87}$, como «servidores de la Palabra» y «colaboradores de Dios en el Evangelio de Cristo» ${ }^{88}$; pues no dudan, que el Señor resucitado les «precederá en la Galilea» de los neopaganos ${ }^{89}$ y allí «estará con» ellos ${ }^{90}$, dándoles, mediante su Espíritu, una palabra poderosa y eficaz ${ }^{91}$, "colaborando con ellos y confirmando la Palabra con signos» maravillosos ${ }^{92}$. Así, avalado su anuncio con la experiencia personal del Símbolo, — «icreemos, por eso hablamos!» (2Cor 4,13)-, van sembrando por «el campo del mundo» la «buena semilla» del anuncio salvífico ${ }^{93}$, experimentando la fuerza ínsita en la «Palabra vivificante» y «salvadora» ${ }^{94}$, la cual, por «no estar encadenada» y sí ser «más cortante que espada de dos filos» ${ }^{95}$, puede «dar la libertad a los oprimidos» por el diablo ${ }^{96} \mathrm{y}$ «abrir los ojos» de los espiritualmente ciegos, «para que se conviertan de las tinieblas» del odio «a la luz» del amor de Dios ${ }^{97}$. Los evangelizadores constatan, en efecto, que a raíz de su reiterado, paciente y gratuito anuncio de «la Buena Nueva a los pobres» de cualquier edad, estado y condición social, «los ciegos ven y los cojos andan, los leprosos quedan limpios, los sordos oyen y los muertos resucitan» ${ }^{98}$ : ‘Así devienen testigos de verdaderos milagros morales! Por lo que no se vanaglorían. Pues para eso se encarga el Señor de darles, al mismo tiempo, «en la carne el aguijón» de persecuciones y peligros, rechazos y desprecios, insultos y calumnias, «trabajos y fatigas» ${ }^{99}$, llevando de ese modo «el tesoro» de la evangelización «en basos de barro, a fin que aparezca que el extraordinario poder [de la Palabra predicada] es de Dios y no de» ellos, quienes «siempre y por doquier experimentan corporalmente la muerte de Jesús, a fin de que también en sus cuerpos se manifieste la vida de Jesús» resucitado en favor de los que evangelizan, pues al "actuar la muerte en» aquéllos, éstos «reciben la Vida» ${ }^{100}$.

c) De ésta dan así testimonio durante dos años, concluyéndose ese período de experiencia y confesión de la Fe recibida con el rito de la «devolución del Símbolo», celebrado antes de la Semana Santa y en el que los neocatecúmenos reviven su bautismal profesión de fe. También esta confesión pública

84. Cf. 2 Cor 5,14-6,10; Act 3,15-20; 10,42-43; 13,32-39 etc. 85. Cf. Rm 6,22-23; Jn 3,1516; 5,24 etc; 1 Jn 5,10-12 etc. 86. Cf. Ef 6,13-18; también: Rm 15,$30 ; \operatorname{Col} 2,1 ; 4,12$. 87. Act 14,3; Cf. 9,27-28; 1Tes 2,2; Ef 6,19. 88. Lc 1,2; 1Tes 3,2. 89. Cf. Mt 26,32 [= Mc 14,28]; 28,$7 ; 4,15$ s. 90. Mt 28,20; Cf Jn 14,18-19. 91. Cf. Jn 14,26; Mt $10,20=$ Lc 12,12. 92. Mc 16,20; Cf. 1Tes 1,5; Gál 3,5; 1Cor 2,4-5. 93. Mt 13,24-27.37-38; Cf. Mc 4,3-8.14-20par. 94. Act 5,20; 13,26; Cf Jn 6,63; 1Jn 3,9; 1Cor 4,15; 1Pe 1,23; Sant 1,21. 95. 2 Tim 2,9; Hebr 4,12. 96. Lc 4,18; Cf. Act 10,38; Jn 8,31-36.44. 97. Act 26,17-18; Cf. Lc 4,18; Jn 8,12; $1 \mathrm{Jn} 1,7 ; 4,8.16$. 98. Mt $11,5=$ Lc 7,22 (Cf. supra, n. 78). 99. 2 Cor 12,$7 ; 11,23-27$. 100. Cf. 2 Cor $4,7-12$. 
del Credo es cuidadosamente preparada con una convivencia de tres días, - dirigida por los catequistas de la(s) comunidad(es)_, en los que momentos de oración comunitaria y personal se alternan con catequesis sobre los «signos» obrados por Jesús con paralíticos (Jn 5,1-18) y ciegos (Jn 9,1-41), hambrientos (Mc 6,30-44par; 8,1-10par) y muertos (Jn 11,1-45), seguidamente concretizadas en un cuestionario, al que cada uno debe responder. Así se preparan de inmediato a confesar públicamente los signos obrados por el Señor en ellos: A dar testimonio de su Credo vivido. Lo hacen - tras sostener individualmente un detenido escrutinio por sus catequistas - en rito solemne y público, del todo sugestivo, presidido por el párroco y sus presbíteros: Una breve monición ambiental sobre la necesidad de confesar la Palabra creída (Rm 10,9-10), como lo hizo Jesús «ante Poncio Pilato» y Timoteo «ante muchos testigos» (1Tim 6,12-13), precede al ingreso de los neocatecúmenos acompañados de sus catequistas; seguidamente se proclama la Palabra sobre la «solemne profesión» de Timoteo (1Tim 6,3-16), el «tan solemne testimonio» de Jesús (Jn 18,1-19,10) y la curación del sordomudo (Mc 7,31-37), tras lo cual, previa la imposición de las manos y una invocación al Espíritu Santo por el Presidente, cada neocatecúmeno devuelve a la Iglesia - allí representada por los presbíteros, catequistas y fieles-el Credo recibido, dando público testimonio de su fe experimentada y recitando seguidamente el Símbolo apostólico. Como en otro tiempo (s. IV) el convertido retórico y filósofo Mario Victorino hizo pública su «devolución del Símbolo» en Roma, así ahora la voz del neoconfesor de la $\mathrm{Fe}$-situado también él «en un lugar eminente» de la presidencia, junto al crucifijo- resuena conmovida y «totalmente segura», poderosa y convincente a los oídos de la silenciosamente presente y atenta «asamblea santa» ${ }^{101}$, que suele acoger y confirmar su testimonio valiente con la rúbrica de un nutrido aplauso. Es éste un momento culminante del Camino neocatecumenal, en el que la bienal experiencia personal y anuncio del Símbolo se concentran en un insólitamente fuerte testimonio de fe cristiana, que sella en lo profundo la vida del confesor y conmovedoramente sobrecoge a sus oyentes, aquél y éstos absolutamente convencidos - al menos ahora- de una cosa: iVale la pena ser cristiano! Este efecto produce en todos la solemne confesión del neocatecúmeno. Tras la cual, se arrodilla aquél ante el Presidente, quien le impone las manos e invoca sobre él «la fuerza del Espíritu Santo, a fin que sea testigo» fiel del Señor resucitado en su aldea o ciudad, en su nación «y hasta los confines de la tierra» ${ }^{102}$, para que, en toda circunstancia y ante todos los hombres, pueda «mantener firme la confesión profesada» ${ }^{103}$. Desde ese momento, el Símbolo es para él un compañero inseparable y, más aún, un fiel amigo: Deviene su «salvaguardia siempre presente» y su «gran defensa» tanto contra las crisis de fe como «contra las tentaciones del adversario», por ser su

101. Cf. san Agustín, Conf. VIII 2,5. 102. Act 1,8; Cf. Lc 24,46-49. 103. Hebr 4,14; Cf. 10,23 . 
"viático durante todo el tiempo de la vida» ${ }^{104}$. El rito se concluye con una oración del Presidente y las preces de la asamblea, el mutuo signo de la Paz y la bendición de aquél, seguida por un canto final que despide a todos, fortalecida su fe «en el Señor y en la fuerza de su poder» $(\operatorname{Ef} 6,10)$.

$\mathrm{El}$ «Domingo de Ramos» reciben solemnemente todos los neoconfesores de la Fe su verde y majestuosa palma, símbolo del Símbolo, signo también de su fe sólida y vertebrada, porque está arraigada en la espina dorsal del Credo ${ }^{105}$. Llevarán luego aquélla a sus casas y la clavarán en su puerta de ingreso, como memorial perpetuo de la $\mathrm{Fe}$, que han confesado y diariamente deben confesar. No sólo eso. Para los vecinos y familiares, amigos y demás visitantes, esa palma - cada año renovada - es también un memorial de lo que aquél es y debe ser: Un confesor de la $\mathrm{Fe}$ o, en otras palabras, un candidato al martirio. Pues el cristiano, a quien la Iglesia entregó la $\mathrm{Fe}$ para que la confiese ${ }^{106}$, es por vocación eso: Un testigo [ = mártir] de la $\mathrm{Fe}$, un confesor del Símbolo.

Pero esa confesión, siempre idéntica en su contenido esencial, varía sin embargo con el tiempo en su expresión, por tener que ser profesada en circunstancias diferentes y ante hombres diversos: Personalmente vivido, para ser eficazmente confesado el Símbolo debe ser interpretado.

\section{La interpretación del Símbolo}

La hermenéutica del Credo de la Iglesia no es producto de la moderna investigación sobre el Símbolo. Aquélla, por el contrario, se remonta a sus mismos orígenes. En efecto, la primitiva fórmula bautismal mateana (Mt 28,19) fue ampliada e interpretada ya por san JUSTINO y san IRENEO, alcanzando una interpretación plena en san HIPÓLITO ${ }^{1}$. También las antiguas confesiones trinitarias de los Padres apostólicos, ampliadas por san JUSTINO, cobran formas cada vez más plenas ya en san IRENEO y, luego, tanto en TERTULIANO como en ORÍGENES ${ }^{2}$. Y si más tarde, como hemos indicado, los Credos teológi$\cos$ de occidente son en realidad interpretaciones del Símbolo romano, del mismo modo que los Credos de oriente interpretan una vetusta Profesión de $\mathrm{Fe}$, eso es también el Símbolo niceno, al que a su vez interpretó tanto el Credo constantinopolitano ${ }^{3}$ como - recientemente- PABLo VI (Cf. infra). No hay duda: La historia del Símbolo se identifica con la historia de su hermenéutica. Su interpretación hodierna ${ }^{4}$, por tanto, no es tarea secundaria sino, más bien, necesidad imperiosa $\mathrm{o}$, en otras palabras:

104. Así lo designan, respectivamente, san Ambrosio (Expl. Symb., 1.9) y san Cirilo J., Cat. V 12. 105. Cf. supra, 8s. 106. San Cirilo J. Cat. XVIII 32.

$\begin{array}{llll}\text { 1. Cf. supra, 17s; infra, nn. 14-15.17. } & \text { 2. Cf. supra, 18. } & \text { 3. Cf. supra, } 22 \mathrm{~s} \text {. 4. Cf. las }\end{array}$ «modernas confesiones de Fe», ofrecidas por E. Bleistein, Kurzformel des Glaubens. II: Texte, Würzburg 1971, 20-85: El a. ofrece asimismo varios «bosquejos de breves fórmulas de fe», reali- 


\section{Una exigencia}

La hermenéutica del Credo, en efecto, fue realizada en las pasadas centurias y continuará realizándose, mientras cambie la historia de los hombres, que lo profesan. Pues al dinamismo de la fe cristiana corresponde la renovada vitalidad del Símbolo, - sintética expresión de aquélla-, cuyas inmutables verdades fueron y serán diversamente formuladas por creyentes siempre diversos y en diferentes circunstancias históricas: A la variación de aquéllos y éstas responde precisamente la siempre renovada hermenéutica del Credo, constitutivo esencial de la fe por él formulada. Esto reflejan sus interpretaciones antiguas (Cf. supra). Y así lo entendió recientemente PABLO VI en su «Solemne Profesión de Fe» ${ }^{5}$, por él redactada repitiendo «sustancialmente - con algunas explicaciones postuladas por las condiciones espirituales de nuestra época- la fórmula nicena», precisando asimismo que «la Iglesia juzga obligación suya no interrumpir los esfuerzos por penetrar más y más en los misterios profundos de Dios... y, a la vez, proponerlos a los hombres de las épocas sucesivas cada día de un modo más apto», no sin «tener sumo cuidado en que, mientras se realiza este necesario deber de interpretación, se derriben verdades de la doctrina cristiana», pues «pertenece a la interpretación o hermenéutica» el esfuerzo «por entender y discernir el sentido contenido en tal texto, pero no innovar de algún modo ese contenido, según la arbitrariedad de una conjetura» ${ }^{6}$. El «Credo» de Pablo VI es, pues, una interpretación del Símbolo niceno: La hermenéutica de la antigua Confesión de Fe, hecha por el actual Magisterio para el creyente hodierno. La reiterada interpretación antigua del Credo, por tanto, continúa siendo un «necesario deber» hodierno. Y a esa tarea insoslayable nos exhorta JUAN PABLO II recientemente, enumerando entre las «condiciones indispensables» de «las obras catequéticas, para responder a su finalidad», la necesidad de conectar «con la vida concreta de la generación a la que se dirigen», así como esforzarse "por encontrar el lenguaje que entiende» aquélla y, a la vez, «decir todo el mensaje de Cristo y de su Iglesia, sin pasar por alto ni deformar nada» "; pues «la catequesis» hodierna, en efecto, «tiene el deber imperioso de encontrar el lenguaje adaptado» a todos los hombres de nuestro tiempo, siendo «el tema del lenguaje sin duda alguna primordial tanto en catequesis como en teología», pero - precisa seguidamente- «la catequesis no puede aceptar ningún lenguaje, que -bajo el pretexto que sea, aun supuestamente científico- tenga como resultado desvirtuar el contenido del Credo" ${ }^{8}$. Reinterpretar en un lenguaje hodierno el inmutable contenido

zados por diversos teólogos (86-102), la trad. alemana del «Credo del Pueblo de Dios» propuesto por Pablo VI (103-13) y la «paráfrasis al [Símbolo] apostólico» de J. Zink (113-17) así como varios credos políticos (118-23), entre los cuales dos ateas «confesiones de fe» comunistas (121-23): ¡Incluso los ateos renuevan su confesión de fe... en la materia y en el futuro del hombre! $\mathbf{5}$. Cf. supra, 31. 6. Pablo VI, o.c., 3-5; texto latino + trad. españ.: C. Pozo, El Credo..., 13-15. 7. Juan Pablo II, Exh. Apost. CT VI 49. 8. Id., o.c., VII 59. 
total del Símbolo: Ésa es la tarea reconocida y encomiada por el actual Magisterio supremo de la Iglesia tanto al exégeta y al teólogo como al pastor y al catequista. ¡Una empresa nada fácil! Para que sea objetiva, exige ante todo detectar:

\section{La unidad y estructura del Símbolo}

El análisis sobre la composición orgánica del Credo ha sido reiteradamente abordado ${ }^{9}$. Y con razón. Pues el contenido y mensaje de un texto sólo puede ser objetivamente apreciado y valorado, tras haber detectado el molde literario, en que fue vertido por su autor, es decir, tras haber logrado desvelar su estructura literaria, para distinguir la(s) idea(s) central(es) de la(s) que, accesoriamente, la(s) complementa(n) y sostiene(n), en la unidad literaria de su temática. ¿Cuál es la estructura lițeraria del Símbolo?

1) Una respuesta a este interrogante - la más generalizada en los catecismos y conocida por los fieles- es la división del Credo en doce artículos, correspondientes a otras tantas verdades centrales de la fe cristiana. Una estrueturación ciertamente antigua: Se enraíza en la vetusta leyenda (s. IV) sobre la composición del Credo por los doce apóstoles ${ }^{10}$, siendo luego generalmente aceptada y divulgada hasta la época del renacimiento ${ }^{11}$. Esta estructuración tiene asimismo el mérito de subrayar y recordar el origen apostólico del Símbolo ${ }^{12}$. Pero, añadámoslo seguidamente, esa estructura docenal del Credo no es objetiva, sino «posterior y artificial» ${ }^{13}$ : Además de apoyarse en un legendario presupuesto histórico, no responde a la composición interna reflejada claramente tanto en las más vetustas fórmulas y Credos bautismales como en las antiguas Confesiones de $\mathrm{Fe}$ y Credos teológicos. ¡La estructura de aquéllos y éstos es otra! ¿Cuál exactamente?

2) El Símbolo de la Fe se formó gradualmente a raíz de la «fórmula bautismal» trinitaria, transmitida por el evangelista san Mateo, según el cual prescribió el Señor resucitado bautizar a todas las gentes «en (=eis) el nombre del Padre y del Hijo y del Espíritu Santo» (Mt 28,19) ${ }^{14}$. Un solo nombre divino, especificado seguidamente por el de las tres Personas: Esa unidad literaria y

9. Cf. a este respecto: A. Harnack, Zur Abhandlung des Herrn Holl zur Auslegung des 2. Artikels des sog. Apostolischen Glaubensbekenntnis: SAB 1 (1919) 112-16; H. Lietzmann, Die Ursprung des Apostolischen Glaubensbekenntnis: «Kleine Schriften» III (TU 74), Berlin 1962, 182-88; A. Jungmann, La Liturgie des premiers siècles, Paris 1962, 139-51; H. de' Lubac, o.c., 5583; W. Kasper, Einführung in den Glauben, Mainz 1972, 95-99 (trad. españ., 122-27); J.N.D. Kelly, o.c., 131-166 (trad. españ., 161-201. 10. Cf. supra, 11. 11. No por todos, sin embargo: El Símbolo fue dividido en 14 artículos por los grandes teólogos medievales (Alejandro de Hales, Summa Theol., III, 3,2, q.2, art. 1; san Buenaventura, In 3 Sent. 25,1; Breviloquium, V 7,2.8; Egidio Romano, De distinctione articulorum fidei: «Opera», I (Roma 1555); el mismo Sto. Tomás (Summ. Theol., II-II, I 8), quien sin embargo mantiene la división docenal en su comentario al Credo (Cf. infra, n. 76). 12. Cf. supra, 12-17. 13. J. A. Jungmann, La Liturgie..., 149; así también H. de Lubac, o.c., 55-60. 14. Cf. supra, 17ss; A. E. Burn, o.c., («An introduction...»), 20-25. 
composición ternaria refleja, pues, ya la fórmula bautismal mateana. Idéntica fórmula reproduce -en el contexto de su catequesis bautismal- el DiDAJISTA ${ }^{15} \mathrm{y}$, más ampliamentente, san JUSTINO, según el cual los cristianos son bautizados «en (=epi) el nombre 1) de Dios, Padre y Soberano del universo, 2) de nuestro Salvador Jesucristo y 3) del Espíritu Santo» ${ }^{16}$ : También aquí la unidad del Nombre divino se especifica en la ternaria mención de las Personas. Muy similar a la fórmula justiniana es la reproducida por san IRENEO, evocando el bautismo recibido 1) «en el nombre de Dios Padre, 2) en el de Jesucristo, Hijo de Dios... y 3 ) en el del Espíritu Santo» ${ }^{17}$, precisando seguidamente, -en un contexto asimismo bautismal-, que la fe 1) en «Dios Padre...» y 2) en «el Verbo de Dios, Hijo de Dios...» y 3) en «el Espíritu Santo...» constituye el «triple pilar», sobre el que descansa «la base del edificio» cristiano ${ }^{18}$. Nuevamente: La fe en las tres Personas divinas, como triple pilar de un edificio, refleja la unidad literaria y estructura ternaria de la fórmula bautismal. Por lo demás, estas fórmulas bautismales primitivas devienen un Credo pleno en san HiPólito, informándonos éste que al bautizando se le interroga 1) «si cree en (=eis) Dios Padre omnipotente, 2) si cree en (=eis) Jesucristo el Hijo de Dios...», y 3) «si cree en (=eis) el Espíritu Santo en (=en) la santa Iglesia» ${ }^{19}$. Ésta [ = la Iglesia] es, pues, el espacio salvífico $(=e n)$, donde se recibe la fe en (=eis) el Espíritu Santo así como en (=eis) el Padre y en (=eis) el Hijo. En otras palabras: El bautismo es conferido, tras constatar la única fe en el nombre de las tres Personas divinas (san Mateo, el Didajista, san Justino), separadamente confesadas (San Ireneo, san Hipólito), es decir, profesando la fe formulada en «el Símbolo de la Trinidad» ${ }^{20}$. No hay duda: El primitivo Credo bautismal refleja la unidad literaria de la única fe cristiana, formulada ésta en una composición literaria claramente ternaria y en correspondencia a su estructura teológica esencialmente trinitaria.

3) Idéntica unidad y composición literaria reflejan también los Credos teológicos o Confesiones de $\mathrm{Fe}$ no directamente relacionados con el bautismo. Ya san IRENEO afirma, en efecto, que «la Iglesia... recibió de los apóstoles... su fe 1) en un solo Dios, Padre todopoderoso..., 2) en un único Cristo Jesús, el Hijo de Dios..., y 3) en el Espíritu Santo...» ${ }^{21}$ : ¡Una fe en el Dios trino! De módo análgo se expresa ORÍGENES, asegurando que «la predicación apostólica» nos ha transmitido 1) (ante todo la existencia de un solo Dios, creador y ordenador de todas las cosas...; 2) en segundo lugar Jesucristo...», y 3) «finalmente [los apóstoles] asociaron al Espíritu Santo en honor y dignidad al Padre

15. Did 7,1.3. 16. IApol. 61,3. 17. Expos., 3. 18. Expos., 7. 19. Trad. Apost., 16-20: Cf. supra, 19. 20. San Cipriano, Epist. 75,11; Cf. 69,7. Así también: San Basilio (De fide, 3-4), san Gregorio Naz., Orat. 40,39-44 (Cf. supra, 20, n. 121), san Juan Cris., Cat. baut., V 19. De modo análogo se expresa un antiguo documento litúrgico, cuando, en el contexto de la «exposición y entrega del Símbolo», afirma sin ambages que «en la Trinidad consiste la fe de todos los cristianos»: Anónimo, Vetus missale gallicanum. XI: Incipit expositio et traditio Symboli (PL 72,349C). 21. Adv. Haer., I 10,1. 
y al Hijo...» ${ }^{22}$; por ello, «1) ante todo hay que creer que existe un solo Dios, creador y modelador de todo...; 2) también tenemos que creer que Jesucristo es Señor...; 3) debemos creer asimismo en el Espíritu Santo...» ${ }^{23}$. La única fe en el Dios trino asegura, pues, no sólo la unidad sino también la estructura ternaria de esas antiguas «Reglas de Fe». Con no menor claridad se evidencia esa unidad y composición en el SIMBOLO ROMANO, profesando «la fe $(=$ credo $) 1)$ en $(=$ in + acus.) Dios, Padre todopoderoso, 2$)$ y en $(=i n+$ acus. $)$ Cristo Jesús, su Hijo..., 3) y en (=in + acus.) el Espíritu Santo...» ${ }^{24}$. Su texto (T) acusa, pues, esta unidad y estructura literaria:

1) en Cristo, Padre todopoderoso;

2) y en Cristo Jesús, su único Hijo, nuestro Señor, que nació del Espíritu Santo y de María Virgen, que bajo Poncio Pilato fue crucificado y sepul-

Creo: $\quad$ tado, al tercer día resucitó de entre los muertos, subió al cielo, está sentado a la derecha del Padre, de donde vendrá a juzgar a los vivos y a los muertos;

3) y en el Espíritu Santo, la santa Iglesia, el perdón de los pecados, la resurrección de la carne»" ${ }^{25}$.

Idéntica unidad literaria y composición ternaria tienen generalmente, asimismo, tanto los CREDOS OCCIDENTALES, derivados de aquél ${ }^{26}$, como los CREDOS ORIENTALES, formulados a raíz de una antigua Profesión de $\mathrm{Fe}^{27}$. Y no de otro modo fue redactado el SíMBOLO NICENO, confesando la única fe de la Iglesia en el Dios trino, es decir, "profesando la fe común (=pistéuomen)» ortodoxa 1 ) «en (=eis) un solo Dios, Padre todopoderoso; 2$)$ y en $(=e i s)$ un solo Señor Jesucristo, el Hijo de Dios..., 3) y en (=eis) el Espíritu Santo» ${ }^{28}$ : ¡Profesión común de la única fe trinitaria! Re-asumida y ampliada luego por el SímBOLO CONSTANTINOPOLITANO, cuya unidad y estructura literaria no deja lugar a dudas:

Creemos:

1) en un solo Dios, Padre todopoderoso, creador...;

2) y en un solo Señor Jesucristo, el unigénito Hijo de Dios, engendrado por el Padre antes de...;

3) y en el Espíritu Santo, el Señor y dador de vida...; esperamos... la vida del mundo futuro.

Amén» ${ }^{29}$.

22. De Princ., I Praef. 4. Análoga estructura ternaria refleja el tratado De Trinitate de Novaciano, escrito hacia la misma fecha (antes del a. 250) y redactado a raíz de un comentario de las tres grandes divisiones de «la Regla de la verdad»: La cual «exige ante todo creer en Dios, Padre y Señor omnipotente...» (I 1), enseñándonos «a creer — después del Padre - en el Hijo de Dios, Jesucristo Señor nuestro...» (IX 46), y «el orden lógico de la demostración a la autoridad de la fe... nos exhorta a creer... también en el Espíritu Santo...» (XXIX 163). Sobre el Símbolo en Novaciano, Cf. C. Blume, o.c., 256-59. 23. In Ev. Ioan., 32,16. 24. Cf. supra, 24; F. Kattenbusch, o.c., II 473-75 25. Denz. 4; J.N.D. Kelly, o.c., 102 (trad. españ., 128); supra, 23, n. 142 (bibliogr.). 26. Cf. supra, 23, n. 143; J.N.D. Kelly, o.c., 173-79 (trad. españ., 210-17): Textos. 27. Cf. supra, 23, n. 144; J.N.D. Kelly, o.c., 182-91 (trad. españ., 220-230): Textos. 28. Cf. supra, 24. 29. Cf. supra, 26. 
Si la inclusión ofrecida por los vocablos sinónimos «creemos»y «amén» asegura la unidad literaria y temática de este Credo, su literaria y teológica estructura ternaria - fiel eclosión final de la original fórmula trinitaria (Mt $28,19)$ - refleja con claridad «las divisiones naturales del Símbolo» ${ }^{30}$, cuya composición ternaria corresponde a su contenido trinitario ${ }^{31}$. Todo el Símbolo, introducido por la fórmula confesional «creo en» y concluido por el corroborante «amén», tiene por contenido la confesión 1) teológica, 2) cristológica y 3) pneumatológica, cada una de ellas articulada en tres, cinco y tres partes respectivamente: Si de Dios confesamos su 1) unicidad, 2) paternidad y 3) actividad creadora, la confesión de «su Hijo Jesucristo» comprende la fe en su 1) encarnación, 2) paśón y muerte, 3) resurrección, 4) ascensión y 5) retorno como juez; finalmente, la confesión del «Espíritu Santo» comprende la fe en 1) la Iglesia y la comunión de los santos, 2) el perdón de los pecados y 3) la vida eterna:

\begin{tabular}{|c|c|c|c|}
\hline & Introducciór & "Cren en" & \\
\hline & & 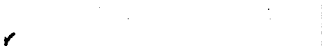 & 1) unicidad \\
\hline & & 1. conf. teológica & 2) paternidad \\
\hline & & (DIOS-PADRE) & 3) actividad creadora \\
\hline & & & 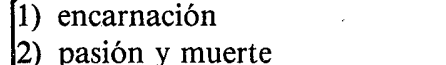 \\
\hline MBOLO & Contenido & 2. conf. cristológica & 3) resurrección \\
\hline & (confesión) & (DIOS-HIJO) & 4) ascensión y glorificación \\
\hline & & & $\begin{array}{l}\text { (5) retorno como juez } \\
\text { (1) Iglesia + comunión santos }\end{array}$ \\
\hline & & 3. conf. pneumatoló- & 2)El perdón de los pecados \\
\hline & & $\begin{array}{l}\text { gica (DIOS-ESPÍ- } \\
\text { (RITU) }\end{array}$ & $\begin{array}{l}\text { 3) resurrección de la carne y la } \\
\text { vida eterna. }\end{array}$ \\
\hline & & & \\
\hline
\end{tabular}

Esta estructura nuestra que el epicentro del Credo cristiano es la confesión cristológica o fe en el misterio salvífico diseñado por el Padre, realizado

30. J. A. Jungmann, o.c., 149. 31. Cf. Id., o.c., 139-42; El sacrificio de la Misa, Madrid 21953, 586; H. de Lubac, o.c., 60-71.76; G. Wingren, Das dreigliedrige Glaubensbexenntinis: $\mathrm{KuD} 4$ (1958) 61-72. En esta línea se situó ya un ilustre pionero de la moderna investigación sobre el Credo, afirmando que «el Símbolo es la ampliada fórmula bautismal» [ $=$ Mt 28,19] y, «como ésta, también aquél tiene una estructura ternaria», siendo «la división en doce artículos una posterior operación artificial, contra la que se opone toda la composición del Símbolo»: A. Harnack, Das Apostolische Glaubensbekenntnis, Berlin 1892, 19; Cf. también recientemente $\mathrm{Ph}$. Schäfer, Einführung in das Glaubensbekenntnis, Mainz 1979, 15s (trad. españ., Santander 1983, 19s). Esa estructura ternaria refleja también, por tanto, el Símbolo niceno (Cf. I. Ortiz de Urbina, o.c., 5361). Ya un teólogo medieval formuló bien esa unidad ternaria del Símbolo, afirmando netamente que «in totis sane tribus Personis una confessio»: Pascasio Radberto, De fide, spe et caritate, I 6, 1 (PL 120,1402). 
por el Hijo y consumado por el Espíritu Santo. Por lo demás, si el centro focal de la confesión teológica es la paternidad de Dios, el de la confesión cristológica lo es la resurrección, siendo el de la confesión pneumatológica el perdón de los pecados. Un solo Dios es, pues, el personal objeto unitario de nuestra fe, ternariamente formulada en la confesión de las tres Personas divinas y de su respectiva obra salvífica: 1) La creación obrada por el Padre, 2) la redención realizada por el Hijo y 3) la santificación operada [en la Iglesia] por el Espíritu Santo.

Esta unitaria estructura literariamente ternaria y teológicamente trinitaria del Símbolo, origen éste o fuente y compendio de la dogmática de la Iglesia (Cf. supra), deberían reflejar - interna y externamente- por tanto los diversos tratados de la teología cristiana, explicitación ésta de aquél (Cf. supra). En todo caso, esa estructura muestra que el Símbolo es como una grandiosa sinfonía, -icantada por el coro de todos los creyentes en Cristo!-, en la que la obertura del «creo en» introduce a la confesión de la única fe, cuya sinfónica orquestación de su triple melodía se concluye con el majestuoso y solemne «amén». A la luz de esa unidad y estructura literaria del Símbolo debe moverse la interpretación de su contenido teológico, para valorar con objetividad tanto el significado de sus verdades centrales como la secuencia y correlación de todas ellas en el común tronco de la confesión trinitaria. Una interpretación, por lo demás, realizada ya —con desigual éxito- desde la antigüedad cristiana, y continuada hasta el presente:

\section{Los intérpretes del Símbolo}

Reproducir todos los antiguos y modernos comentarios al Credo sería un trabajo ingente y, además, exigiría varios volúmenes. Hemos renunciado desde un principio a tal empresa. Tampoco serviría a la finalidad de nuestra obra, mucho más modesta y desde luego más práctica: Ofrecer al cristiano hodierno una antológica selección representativa de comentarios catequéticos y teológicos al Símbolo, - completados por uno nuestro-, en los que se refleje claramente la Fe de la Iglesia, condensada en el Símbolo ${ }^{32}$. Nada mejor, para ello, que escuchar ante todo a quienes, desde antiguo, fueron sus mejores intérpretes, - los Padres y Doctores de la Iglesia-, por haber contribuido eficazmente a «generar» la dogmática cristiana o a dar forma concreta y permanente a sus verdades así como desarrollar su contenido, deviniendo por ello tanto cualificados maestros de la teología del cristianismo como reconocidos representantes de la tradición de la Iglesia; cuyo Magisterio - paráfrasis y comentarios al Símbolo- introduciremos asimismo en nuestra selección antológica, por ser el divinamente constituido intérprete y garante de la ortodoxia cristiana: ¡A aquéllos y, sobre todo, a éste deben consultar incesantemente los exégetas y teólogos, para «saber si corren o no en vano»! (Gál 2,2).

32. Cf. supra, $4 \mathrm{~s}$. 
1) Nuestra selección antológica está encabezada por el testimonio de los PADRES APOSTÓLICOS y de los APOLOGISTAS GRIEGOS: Aquéllos, del todo cercanos al Nuevo Testamento, enlazan directamente con la revelación neotestamentaria y son, por ello, cualificados e imprescindibles testigos «ad intra» de la fe cristiana; no les ceden en importancia los Apologistas del s. II, los primeros teólogos de la Iglesia así como los primeros confesores «ad extra» de la fe de la Iglesia ante la cultura y religión pagana, contribuyendo por lo demás decisivamente - san JUSTINO sobre todo- a la formación del Símbolo ${ }^{33}$. Más decisiva fue la aportación de san IRENEO (ca. 140-202): Eximio catequista y apologeta así como el mayor teólogo de su tiempo, es también cualificado testigo tanto del Símbolo bautismal como de la «Regla de fe» o compendio de la dogmática de la Iglesia ${ }^{34}$. Ese doble testimonio de la fe cristiana ofrece asimismo la rica obra de TERTULIANO (ca. 155-215), cuyos datos y textos son de la mayor importancia para la historia del Credo ${ }^{35}$ o «el Símbolo». Así designado aquél por vez primera por san CIPRIANO (ca. 205-258) y, por tanto, testigo del «Símbolo de la Trinidad», al que selló con su martirio ${ }^{36}$. El alejandrino san CLEMENTE (ca. 150-215), no sólo director de la escuela catequética de su ciudad sino también pionero de la sintonía entre cultura pagana y teología cristiana, fue un gran educador de la fe - iel «Pedagogo»! - y, por tanto, merece un puesto entre los antiguos representantes del Credo, compendio de

33. Cf. supra, 18. Textos en: A. Hahn-G.L. Hahn, o.c., 1-5; J.N.D. Kelly, o.c., 68-75 (trad. españ., 90-98). Todos los abundantes testimonios de ese período fueron recogidos por A. Harnack (Materialien zur Geschichte und Erklärung des alten römischen Symbols aus der christlichen Literatur der zwei ersten Jahrhunderte: A. Hahn-G.L. Hahn, o.c., 364-90), cuya autorizada valoración no deja lugar a dudas: «Das ganze Material ist natürlich für ein gesichertes Verständnis des Inhalts und für die Entzifferung des Ursprungs des Taufbekenntnis von hohem Werth» (365). Sobre los Padres apostólicos, Cf.: S. Bäumer, o.c., 139-57; C. Blume, o.c., 261 (=San Ignacio); A.E. Burn, o.c., 26-31; F. Kattenbusch, o.c., II 310-22; J.N.D. Kelly, o.c., 65-70 (trad. españ., 87-93). Sobre los Apologistas griegos y, en especial, san Justino, Cf.: S. Bäumer, o.c., 133-38; C. Blume, o.c., 259-61; A.E. Burn, o.c., 33-44; F. Kattenbusch, o.c., II 279-310; J.N.D. Kelly, o.c., 43-44.70-76 (trad. españ. 61-62.93-99). 34. Cf. supra, 18, nn. 104.107. A este respecto, Cf.: S. Bäumer, o.c., 120-22; C. Blume, o.c., 253-56; A.E. Burn, o.c., 41-44; F. Kattenbusch, o.c., II 25-53; B. Reinders, Parádosis. Le progrés de l'idée de la tradition jusqu'à saint Irenée: RThAM 5 (1933) 155-91; H. Holstein, La tradition des Apôtres chez saint Irenée: RSR 36 (1949) 229-70; B. Haeglund, Die Bedeutung «regula fidei» als Grundlage theologischer Aussagen: StTh 12 (1958) 1-44:4-19; V. Grossi, Regula veritatis et narratio battessimale in Sant' Ireneo: Aug 12 (1972) 437-63; J.N.D. Kelly, o.c., 76-82 (trad. españ., 99-104). 35. Cf. supra, 18. A este respecto, Cf.: S. Bäumer, o.c., 114-19; C. Blume, o.c., 239-48; A.E. Burn, o.c., 48-57; F. Kattenbusch, o.c., I 141-44; II 53-94; A D'Ales, La théologie de Tertullien, Paris ${ }^{2} 1905,254-61$; Id., Tertullien. Symbolum: RSR 26 (1936) 468; F. Dölger, Die Eingliederung des Taufsymbols in den Taufvollzurg nach den Schriften Tertullians: AuC 4 (1933) 138-46; J.M. Restrepo-Jaramillo, La doble fórmula simbólica en Tertuliano: Gr 15 (1934) 3-58; J. Crehan, Early christian baptism and Creed, London 1950, 82-88; B. Haegelund, a.c., 19-29; G.G. Blum, Der Begriff des Apostolicum im theologischen Denken Tertullians: KuD 9 (1963) 102-121; J. Quasten, Patrología, I 620s; J.N.D. Kelly, o.c., 44-45.82-88 (trad. españ., 62-63.106-112). 36. Textos en A. Hahn-G.L. Hahn, o.c., 16s; Cf. a este respecto: S. Bäumer, o.c., 109-110; C. Blume, o.c., 249-50; F. Kattenbuscn, o.c., II 372-77; J.N.D. Kelly, o.c., 46 (trad. españ., 64). 
la «regla eclesiástica» ${ }^{37}$. Lo merece sobre todo ORígenES (a. 185-253): Pensador y teólogo de encumbrada talla, fue un eximio testigo de la fe de la Iglesia y uno de los más decisivos generadores de la dogmática cristiana ${ }^{38}$. Los también alejandrinos san ATANASIO (a. 295-373) y san CIRILO (+444), -ilustre defensor aquél de la $\mathrm{Fe}$ nicena y campeón éste de la ortodoxia antinestoriana-, son asimismo - y por ello- cualificados representantes de la Fe de la Iglesia ${ }^{39}$. 'También lo son los tres grandes PADRES CAPADOCIOS, por su decisiva contribución a la defensa y desarrollo del dogma trinitario y, en especial, de la teología pneumatológica ( san Basilio!) ${ }^{40}$. El primer gran comentarista del Símbolo fue san CIRILO Jerosolimitano (a. 315-387) en sus famosas «Catequesis» (a. 350): Si en las cuatro últimas [ = mistagógicas] instruye a los «neófitos» ${ }^{41}$, la protecatequesis así como las 18 primeras catequesis pre-bautismales se dirigen a «los iluminados» o catecúmenos, a quienes, tras proponerles «el fundamento» del «edificio de la fe» ${ }^{42}$, les expone ésta y el Símbolo ${ }^{43}$, al que seguidamente comenta ${ }^{44}$ a raíz de una explicación bíblica, teológica y catequética, en un esfuerzo por «expresar con lenguaje espiritual las realidades del Espíritu» ${ }^{45}$. También los PADRES ANTIOQUENOS, representados por Teodoro M. $(+428)$ y san Juan Cris. $(+405)$, son ilustres representantes del Credo ${ }^{46}$, por ser ambos defensores de la ortodoxia formulada en el Símbolo niceno y constantinopolitano: Aquél comentó el Credo en sus diez primeras «Homilías catequéticas» (ca. 388-392) para los catecúmenos de su comunidad eclesiástica ${ }^{47}$, con el fin de "destruir el error e instruir a la

37. Frecuentemente mencionada (Strom. I 96,1; 167,$1 ;$ III 66,$1 ; 77,1 ; 105,1 ; 109,2 ;$ IV 15,4 ; 98,3; 101,1; VI 131,1; VII 13,4; 41,3); Cf. a este respecto: B. Haeglund, a.c., 30-34. Sobre «el Símbolo» y «la Regla de Fe» en Clemente A., Cf. F. Kattenbusch, o.c., II 102-134. 38. Cf. supra, 18; F. Kattenbusch, o.c., II 134-79; D. van den Eynde, Les normes de l'enseignement chrétien, Paris 1933, 308ss; A.C. Outler; Origen and the «regula fidei»: ChH 8 (1939) 212-21; R.P.C. Hanson, Origen's doctrine of tradition: JThS 49 (1948) 17-27; R.C. Baud, Les «regles» de la théologie d'Origène: RSR 55 (1967) 161-208:177-80.187-200; J.N.D. Kelly, o.c., 92s (trad. españ., 117s); R. Trevijano, Orígenes y la «regula fidei»: AA.VV., Origeniana, Bari 1975, 327338. 39. A. Hahn-G.L. Hahn reproduce el texto del Credo de san Atanasio (o.c., 264s) y de san Cirilo (o.c., 310-16). Sobre la importancia de san Atanasio para el Símbolo, Cf. F. Kattenbusch, o.c., I 320-36:333ss; II 242-61. 40. Textos del Símbolo en A. Hahn-G.L. Hahn, o.c., 148-51.269s. Sobre san Basilio, Cf. F. Kattenbusch, o.c., I 342-48.366s. 41. Cat. XIX-XXIII. 42. Cat. I-IV. 43. Cat. V. 44. Cat. VI-XVIII. 45. Cat. XVII, 1. Sobre la importancia de san Cirilo para el Símbolo, Cf. S. Bäumer, o.c., 93-96; A.E. Burn, o.c., 66-69; F. Kattenbusch, o.c., I 40-46.233-44.399-401; J.N.D. Kelly, o.c., 33s (trad. españ.; 50s). El texto del Credo usado por el obispo jerosolimitano (Cf. Cat. V 12) ha sido reconstruido por A.A. Stephenson, The text of the Jerusalem Creed: StPatr 3 (1961) 303-13; Cf. A. Hahn-G.L. Hahn, o.c., 132-34. Una visión panorámica de la catequesis sobre el Credo y de los ritos sobre la «traditio» y «redditio Symboli» en Jerusalén, en tiempo de san Cirilo, ofrecen: F. Kattenbusch, o.c., II 399401; H. Leclercq, a.c. (DACL, II), 2561-66; P. de Puniet, a.c. (DACL, II) 2593-95; más bibliografía, al respecto, supra, 20, n. 128 46. Texto del Símbolo antioqueno en A. Hahn-G.L. Hahn, o.c., 141-43; texto de Teodoro M. en: Id., o.c., 302-8; J.N.D. Kelly, o.c., 187s (trad.españ., 226). Cf. a este respecto: F. Kattenbusch, o.c., I 220-23; J.N.D. Kelly, o.c., 184s.187s (trad. españ., 223s.226s). Sobre san Juan Crisóstomo, Cf. C.P. Caspari, Alte und neue Quellen zur Geschichte des Taufssymbols und der Glaubensergeln, II, Christiana 1869 (repr. Bruxelles 1964), 225-244. 
Iglesia», refutando «mediante sus [ = Credo] breves palabras a quienes se oponen a la verdadera fe» ${ }^{48}$; y ésta defendió con ahínco también su amigo Juan, cuya nutrida obra exegética, teológica, apologética y catequética le merece un puesto entre los antiguos representantes del Símbolo. Lo son también los occidentales san HILARIO (+367) y san AMBRosio (ca. 337-397): En el tratado «Sobre la Trinidad» de aquél, afirma que la fórmula bautismal (Mt 28,19) "contiene todo lo referente al misterio de la salvación» (II 1) y, tras exponer la doctrina trinitaria (II 2-XII 56), se concluye con una sentida plegaria del autor por su fidelidad «a la verdad, que he profesado en el Símbolo de mi regeneración...» ${ }^{49}$, siendo aquel tratado, asimismo una de las más logradas exposiciones de la ortodoxia cristiana; no le cede en rango el obispo milanés, a quien por lo demás debemos un breve pero sugestivo comentario al Símbolo ${ }^{50}$, «breviario de la fe» formulado por «los santos Apóstoles» ${ }^{51} \mathrm{y}$ «entregado» a los «competentes», para que lo retengan «en la memoria diariamente» como «una gran defensa», y lo «devuelvan» a la Iglesia o públicamente lo confiesen ${ }^{52}$. Breve y denso es también el comentario al Credo del obispo de Remesiana NiCETAS (+ ca. 420) en el libro V de su «Instructio ad compentes» ${ }^{53}$, dirigido a éstos como exposición del Símbolo, que «en pocas palabras contiene todos los misterios, coleccionados brevemente de todas las Escrituras como preciosas perlas de una corona regia, a fin que tanto ignorantes como cultos posean una suficiente ciencia salvífica» ${ }^{54}$ : ¡No hemos renunciado a este testigo del Credo! Lo fue también el monje y traductor RUFINO de Aquileia

47. Descubiertas (a. 1932) y publicadas (texto siríaco + trad. inglesa) por vez primera por A. Mingana (Commentary of Theodore of Mopsuestia on the Nicene Creed, Cambridge 1932; Id., Commentary of Theodore of Mopsuestia on the Lord's Prayer and on the Sacraments of Baptism an the Eucaristy, Cambridge 1933), fueron todas ellas publicadas más recientemente por $\mathrm{R}$. Tonneau-R. Devresse, Les Homélies catéchétiques de Théodore de Mopsueste, Ciudad del Vaticano 1949; una síntesis de la explicación teodoriana al Símbolo ofrece R. Tonneau, o.c., XVIIXXV. Sobre las Catequesis de Teodoro, en general, Cf. J. Quasten, Patrología, II 427-29 (bibliogr.). 48. Hom. II 4. Teodoro evoca expresamente los Conc. Niceno (Hom. III 12; IX 1) y Constantinopolitano: Hom. III 4; IX 14. 49. De Trin., XII 57. Sobre el Símbolo en san Hilario, Cf.: S. Bäumer, o.c., 77-78; F. Kattenbusch, o.c., I 379-87. 50. Explanatio Symboli ad initiandos (PL 17,1193-96; SCh 25bis, 46-59): Cf. C.P. Caspari, o.c., II 48-127. Sobre su autenticidad ambrosiana, Cf.: R.H. Connelly, St. Ambrose and the «Explanatio Symboli»: JThS 47 (1946) 185-90; Id., The «Explanatio Symboli ad initiandos». A work of St. Ambrose, Cambridge 1952; B. Botte, Ambrose de Milan. Des Sacramentes, Des Mystères, L'Explication du Symbole (SChr 25bis), Paris 1961, 21-25. 51. O.c., 2-3.7. 52. O.c., 1.9; Epist. 20,4. Sobre la «traditio» y «redditio Symboli» en la iglesia de Milán, Cf.: P. de Puniet, a.c., 2614-17:2616; B. Arezzo, La catechesi di Sant'Ambroggio, Genova 1957, 55-84:65-67; V. Monachino, San Ambrogio e la cura pastorale d Milano nel s. IV, Milano 1973, 46-79:47. El texto del Símbolo milanés es ofrecido por: a. Hahn-G.L. Hahn, o.c., 36s; J.N.D. Kelly, o.c., 173 (trad. españ., 210). Cf. a este respecto: S. Bäumer, o.c., 70-77; A.E. Burn, o.c., 205-209; F. Kattenbusch, o.c., I 392ss; II 439s. 53. Explanatio Symboli, 1-14 (PL 52, 847-76:865-74). El texto del Símbolo usado por Nicetas (o.c., 1) es ofrecido por A. Hahn-G.L. Hahn, o.c., 47-49. Cf. a este respecto: S. Bäumer, o.c., 69-70; A.E. Burn, o.c., 252-55; F. Kattenbusch, o.c., I 403-7; II 440-43. 54. O.c., 13. 
(ca. 345-410) en su comentario (ca. 404) al Credo ${ }^{55}$ : Redactado éste por «los Apóstoles» como «breve indicio de» su predicación ${ }^{56} \mathrm{y}$ «torre de la fe» cristiana ${ }^{57}$, la explicación teológica de sus doce artículos se propone sostener a «los incipientes» en la fe ${ }^{58}$. El máximo comentarista antiguo del Símbolo es sin duda alguna san AGUSTÍN ${ }^{59}$ : Nueve veces abordó su explicación (a. 391421) tanto en dos obras teológicas ${ }^{60}$ como en siete Sermones sobre el Credo ${ }^{61}$, seis de los cuales ${ }^{62}$ dirigidos a los «competentes» de su iglesia con ocasión de la «traditio Simboli» [el sábado antes del $4 .^{\circ}$ domingo de cuaresma], para desvelarles el rico venero de «la sucinta fórmula de la Fe» ${ }^{63}$, que, sin escribirla y sí aprendiéndola de memoria ${ }^{64}$, deberían luego «devolverla» [ = «redditio Symboli»] de modo privado primero [=el sábado antes del $5 .^{\circ}$ domingo de cuaresma] y solemnemente luego el día [ = Sábado Santo] de su regeneración bautismal ${ }^{65}$; por lo demás, el Credo ocupa también «un lugar destacado» en otras obras del obispo hiponense ${ }^{66}$, «de importancia decisiva para la historia de la valoración del Símbolo» que, con la aportación agustiniana, recobró «nueva vida» ${ }^{67}$. Es lo que refleja el comentario catequético de su amigo y discípulo, el obispo cartaginés san QUODVULTDEUS, en sus tres «Sermones sobre el Símbolo» para los «competentes de Cartago, predominando el interés del pastor por desvelarles «el sacramento del Símbolo» ${ }^{68}$. Análogo interés refle-

55. Explanatio Symboli, 1-46 (CC,XX 133-82). El texto del Símbolo de Aquileia es ofrecido por: A. Hahn-G.L. Hahn, o.c., 42s; J.N.D. Kelly, o.c., 174 (trad. españ., 211). Cf. a este respecto: S. Băumer, o.c., 65-68; A.E. Burn, o.c., 201-205; F. Kattenbusch, o.c., I 46-47.102-30; II 43336; M. Villain, Rufin d'Aquilée, commentateur du Symbole des Apôtres: RSR 34 (1944) 129-56; J.N.D. Kelly, Rufinus. A commentary on the Apostles' Creed, London 1955. Ignoramos por qué omitió la mención de esta obra J. Bribomont, Rufino de Aquileia, en: «Patrología», III, Madrid 1981, 291-300 (igrave «lapsus» del patrólogo!). 56. O.c., 2 . 57. O.c., 3-45. 58. O.c., 16.36.41. 59. Cf.: C.P. Caspari, o.c., II 264-82; S. Bäumer, o.c., 58-65; A.E. Burn, o.c., 21013; F. Kattenbusch, o.c., I 47.51-53.136-39; II 403-442.445-47; C. Eichenseer, Das Apostolicum bein hl. Augustinus, St. Ottilien 1960, 136ss; J.N.D. Kelly, o.c., 175s (trad. españ., 212s). 60. Cf. De agone christiano (ca. 398), XII 13-XXXIII 35 (Cf. C. Eichenseer, o.c., 149s); Enchiridion (ca. 421), VIII 2-CXIII 19. 61. Cf. De fide et symbolo: PL 40,181-96; CSEL 41 , 1-32 (a. 391: Cf. C. Eichenseer, o.c., 148s); Serm. ad catech. de Symbolo (PL 40,627-36; CC 46,185-99); Serm. 216 (ca. 393: PL 38,1076-82); de los a. 410-12 son los Serm. 212 (SCh 116,17484).213 (PLS, II 536-43).214 (RBén 72,14-21). 215 (RBén 68,18-25): Cf. C. Eichenseer, o.c., 14648; P. Verbraken, Études critiques sur les sermons de saint Augustin, Steenbrugis (Bélgica) 1976, 104-106. Trad. españ. de los Serm. 212-16 ofrece A. Fueyo, Sermones de san Agustín, V, Madrid 1928, 44-78. - 62. Serm. ad catech. de Symbolo + Serm. 212-216. 63. Serm. 212,2; así también: Serm. 212,1;213,1;58,1;59,1; De fide et symbolo, I 1. 64. De fide et symbolo, I 1; Serm. 58,1.13; 213,10;214,1.2; Serm. ad catech. de Symbolo, 1 . 65. Sobre la «traditio» y «redditio Symboli» en África, Cf.: F. Kattenbusch, o.c., II 51-53; P. de Puniet, a.c., 2595-98: 2597; F. van der Meer, Augistinus der Seelsorger, Köln 1953, 375s; C. Eichenseer, o.c., 133-45; V. Grossi, La liturgia battessimale in S. Agostino (SEA 7), Roma 1970, 55-60; más bibliografía, supra, 20, n. 128. 66. Cf. C. Eichenseer, o.c., 151-54. Está, pues, justificada la inclusión de textos agustinianos de otras obras (además de las mencionadas) en nuestra antología. 67. F. Kattenbusch, o.c., II 397.403. Texto del Símbolo usado en Hipona ofrece: A. Hahn-G.L. Hahn, o.c., 38-39.58s; J.N.D. Kelly, o.c., 176s (trad. españ., 213s). 68. Sermones I-III de Symbolo 
jan los comentarios asimismo catequéticos al Credo de los obispos italianos san MÁxIMo de Turín (+ ca. 415) ${ }^{69}$ y san PEDRo Crisólogo (+ ca. 450 ) ${ }^{70}$, cualificados representantes del Símbolo. También lo son -aunque no lo hayan comentado - los papas romanos san LEÓN Magno $(+461){ }^{71}$ y san GREGORIO Magno ( + a. 590-604) ${ }^{72}$, con los que respectivamente se cierra la edad antigua y se abre la edad media. Los comienzos de la exposición medieval sobre el Símbolo están muy bien representados por el arzobispo español san ILDEFONSO de Toledo ( +667$)$, en el contexto de su tratado sobre el bautismo ${ }^{73}$ : Tras una introductoria exposición sobre el porqué de la «traditio Symboli» a los «competentes», - para que reciban «la fe ortodoxa» y vivan según ella, una vez bautismalmente regenerados-, así como sobre la motivación, nombre y naturaleza del Símbolo ${ }^{74}$, aborda el comentario teológico y catequético a cada uno de sus artículos ${ }^{75}$, a fin que aquéllos «creyendo, se sometan a Dios, sometiéndose a Él, vivan rectamente, viviendo así, purifiquen su corazón y, purificado éste, entiendan lo que creen» ${ }^{76}$. Las diversas explicaciones medievales sobre el Credo ${ }^{77}$ encuentran una cima en el históricamente instructivo y teológicamente denso comentario al Símbolo apostólico de Sto. TOMÁS de Aquino ${ }^{78}$, escrito - a raíz del «texto recibido» [T] - poco antes de su

(CC 60,305-363); Cf. V. Grossi, Quodvultdeus: «Patrología», III 600-3:602. 69. Hom. 83 (PL 57,433-440); texto del Símbolo en: A. Hahn-G.L. Hahn, o.c., 40s; J.N.D. Kelly, o.c., 174 (trad. españ., 211). A este respecto, Cf. F. Kattenbusch, o.c., II 447. Sobre el autor y su obra, Cf. B. Studer, Máximo de Turín: «Patrología», III 699-701. 70. Serm. 56-62 (PL 52,354-75; CC 24,314-52); Cf. a este respecto A. Olivar, Los sermones de san Pedro Crisólogo, Monserrat 1962, 171-73; a esos sermones hay que añadir otra «Expositio Symboli»: Cf. A. Olivar, o.c., 369-84. Sobre el autor y su obra, Cf. B. Studer, Pedro Crisólogo: «Patrología», III 701-4. Texto del Símbolo usado en Ravenna ofrecen: A. Hahn-G.L. Hahn, o.c., 41s; J.N.D. Kelly, o.c., 174 (trad. españ., 211). A este respecto, Cf. F. Kattenbusch, o.c., I 101s; II 443-45. 71. Texto del Símbolo en A. Hahn-G.L. Hahn, o.c., 27.321-330; Cf.: S. Bäumer, o.c., 51-54; F. Kattenbusch, o.c., II 423s. Sobre el autor y su obra, Cf. B. Studer, León Magno: «Patrología», III 719-47. 72. Texto del Símbolo, por él usado: A. Hahn-G.L. Hahn, o.c., 28-30.337s. Sobre el autor y su obra, Cf.: L.M. Weber, Gregor I der Grosse: LThK, IV 1177-80; B. Altaner, Patrología, Madrid 21962 , 460-65. 73. De cognitione Baptismi, 31-95 (PL 96, 111-172); texto latino + trad. española ofrece J. Campos, San Ildefonso de Toledo, Madrid 1971, 236-78. Texto del Símbolo, por él usado: A. Hahn-G.L. Hahn, o.c., 66; Cf. a este respecto F. Kattenbusch, o.c., I 154s; II 459s. 74. O.c., 31-35. 75. O.c., 36-95. 76. O.c., 95. 77. Cf. Amalario de Tréveris, Epist. de ceremoniis Baptismi (PL 99,896); Rábano Mauro, Hom. XIII in Dom. 2 Quadragessimae (PL 110,2729); De ecclesiastica disciplina, 2 (PL 112,124-26); San Bruno Herbipolense, Comment. in Symb. Apost. (PL 142,551-61); Ivo Carnotense, Serm. 23 (PL 162,604-7); Abelardo, Expos. Symboli quod dicitur Apostolorum (PL 178, 617-30); Id., Expositio fidei in Symbolum Athanasii (Ib., 629-32); Joslenio de Soissons, Expos. Symboli (PL 186,1479-88). La musa medieval se inspiró no sólo en el Padrenuestro (Cf. S. Sabugal, La Oración del Señor, Madrid 1984, 19-26) sino también en el Credo: Cf. H. Walther, Verzifizierte Paternoster un Credo: RMA 20 (1964) 45-64:57ss. 78. In Symbolum Apostolorum expositio: "Oppuscula Theologica», II (ed. R.M. Spiazzi), Roma 1954, 193-217 (bibliogr.: 192). Sobre el Símbolo, Cf. también Id., Summa Theol., II-II 1,8-10: Puesto que «la Iglesia universal no puede errar, por estar dirigida por el Espíritu Santo» y «el Símbolo ha sido promulgado por la autoridad de» aquélla, en él «no hay nada inexacto» y sí se contiene «la colección de todas las verdades de la fe» $(1,8-9)$, competiendo «una nueva pro- 
muerte (probablemente a. 1273) y, por tanto, síntesis de su teología y experiencia mística: ¡Excelente comentario! También lo es el comentario al «Símbolo Apostólico» [ = T] del CATECISMO ROMANO ${ }^{79}$, promulgado (a. 1566) por san Pío V tras haber sido elaborado por una comisión de teólogos, -nombrados por los Padres conciliares de Trento-, como «presentación eficaz de las doctrinas fundamentales del cristianismo ${ }^{80}$; esa finalidad anima toda la obra, cuya primera parte, tras un breve tratado «sobre la fe y el Símbolo" ${ }^{81}$, aborda el comentario bíblico, patrístico, teológico y catequético al Credo ${ }^{82}$, que influirá decisivamente sobre los comentarios católicos al Símbolo en las siguientes centurias; y puesto que «la fe tridentina permanece fe de la Iglesia» ${ }^{83}$, está justificada su inserción en nuestra antología. De ésta no podía faltar naturalmente el testimonio conciliar y papal del antiguo y hodierno MAGISTERIO de la Iglesia, por el que debe ser guiado el Pueblo de Dios ${ }^{84}$, bajo cuya «vigilancia» tienen que trabajar tanto exégetas como teólogos católicos ${ }^{85}$, cuyos «documentos deben conocer bien los presbíteros» ${ }^{86}$ y a la luz de los cuales tienen que «enseñar los catequistas» ${ }^{87}$; en el contexto del Magisterio hodierno sigue ocupando un puesto de relieve la «Profesión solemne de Fe» o «El Credo del Pueblo de Dios» formulado por PABLO VI, justamente considerado por un ilustre teólogo (J. Card. Daniélou) como «norma de toda catequesis», y valorado por Juan Pablo II como «referencia segura para el contenido de» aquélla ${ }^{88}$. Puesto que «únicamente al Magisterio de la Iglesia fue encomendado [por Dios] el oficio de interpretar auténticamente la Palabra de Dios oral o escrita» ${ }^{89}$, su paráfrasis o interpretación del Símbolo debe ser normativa para el creyente católico.

2) Esa selección antológica podría ser ampliada, naturalmente, con textos de numerosos comentarios católicos modernos al Símbolo de la $\mathrm{Fe}^{90}$. Pero

posición del Símbolo a la autoridad del Sumo Pontífice», por ser él garante de «la unidad de la fe en toda la Iglesia» $(1,10)$. De ạí que su Exposición del Símbolo apostólico condense la explicación de todas las verdades de la fe cristiana: ¡Una mini-«Suma Teológica»! 79. Texto latino (A. Hahn-G.L. Hahn, o.c., 32s) + trad. española ofrece P. Martín, Catecismo Romano, Madrid 1956; Cf. a este respecto H. Jedin, Geschichte des Konzils von Trient, IV. 2, Freiburg 1975, 257s. 80. O.c., pról. 8. 81. O.c., I: De fíde et Symbolo, 1-4. 82. O.c., I, art. 1-12. 83. H. Jedin, o.c., 258. Juan XXIII aconsejaba para la predicación y catequesis el uso del Catecismo Romano (Cf. AAS 1960, 213s), sin duda por ser «excelente» (K. Rahner, Curso fundamental de la fe [trad. españ.], Barcelona 1979, 517) y constituir «una obra de primer orden, resumen de la doctrina cristiana y de la doctrina tradicional» (Juan Pablo II, Exh. Apost. CT 13). Se comprende, pues, las recientes traduciones italianas (Ed. Paulinas, Catechismo del Concilio di Trento, Roma 1961; T.S. Centi, Catechismo Romano, Siena 1981; L. Andrianopoli, Il Catechismo Romano comentato, Milano 1983), sin que se deba exagerar su actualidad (como lo hace P. Rodríguez, Attualità del Catechismo Romano: P. Andrianopoli, o.c., XIII-XX): Porque la fe de Trento no es toda la fe de la Iglesia ni responde a las exigencias actuales, nuestra época necesita su Catecismo. 84. Cf. Conc. Vat. II, Const. LG 12. 85. Conc. Vat. II, Const. DV 23. 86. Conc. Vat. II, Decr. PO 19. 87. Juan Pablo II, Exh. Apost. CT 61. 88. Cf. supra, 39, n. 66. 89. Conc. Vat. II, Const. DV 10; Cf. Decr. UR 21. 90. Cf. por ejemplo: I. Ortiz de Urbina, El Símbolo niceno, Madrid 1947, 63-266; J. Ratzinger, Einführung in das Christentum, 
ello agigantaría el volumen de nuestra obra y, por lo demás, dificultaría su acceso al lector común, al que también la dirigimos. Hemos renunciado por ello - iy con pena! - a esa empresa. No del todo, sin embargo. Tendremos en cuenta, efectivamente, esos estudios, -algunos del todo instructivos y alicientes-, en el comentario personal a cada artículo del Credo, con el que introducimos y completamos aquella antología: Una breve exposición histórica sobre la génesis, formación y significado de cada artículo introducirá su respectiva explicación antológica, seguida ésta por un comentario bíblico y catequético al mismo, en el que nos esforzaremos por hodiernizarlo o interpretar su contenido teológico en conceptos y lenguaje asequibles al lector de hoy. ¿Finalidad de esta interpretación? Una sola: Desvelar el antiguo y siempre nuevo mensaje del Símbolo, en el intento de mostrar - a su luz - la respuesta, que la $\mathrm{Fe}$ de la Iglesia ofrece a los interrogantes existenciales del creyente hodierno.

Una Fe profesada por el autor y propuesta a sus lectores en el siguiente Símbolo para nuestro tiempo, síntesis y ampliación bíblica de los antiguos Credos de la Iglesia así como de su posterior doctrina dogmática ${ }^{91}$ :

Mïnchen 1968 (trad. españ.: Introducción al Cristianismo, Salamanca 1971); W. Beinert, Das Glaubensbekenntnis der Oekumene, Freiburg 1973, 41-142; W. Sandfuchs (Hrsg.), Ich glaube, Würzburg 31975 (trad. ital., Assisi 1977); AA.VV. (=Obispos franceses), La Foi de l'Eglise, Paris 1978, 47-433; Ph. Schäfer, Einführung im das Glaubensbekenntnis, Mainz 1979 (trad. españ., Santander 1983); G. Ferraro, Il Simbolo de la Fede, Roma 1980, 33-149; O. González de Cardedal (ed.), El Credo de los cristianos, Madrid 1982; AA.VV., El Credo. Reflexiones sobre la Fórmula de Fe del Pueblo de Dios, Madrid 1982. Desde el punto de vista catequético, ofrecen un comentario al Símbolo de la Fe los Catecismos católicos de: A. Baur-W. Plöger, Botschaft des Glaubens. Ein katholischer Katechismus, Donauwörth (Essen) 1978; AA.VV., Grundriss des Glaubens, München 1980 (2. ${ }^{a}$ parte: Comentario al Credo). Obispos alemanes, Katholischer Erwachsenen-Katechismus. Das Glaubensbekenntnis der Kirche, München-Stuttgart 1985. 91. Las ampliaciones introducidas en este Símbolo pueden extrañar sólo a quien ignore, que recientemente Pablo VI formuló su «Solemne Profesión de Fe» repitiendo «sustancialmente - con algunas explicaciones postuladas por las condiciones espirituales de esa época- la fórmula nicena...». (Cf. supra, 47, n. 6), sensiblemente ampliada por ello en ese Credo. Por lo demás, ya un pionero de la investigación sobre el Símbolo precisó que, omitiendo éste «la alusión a la predicación» de Jesús así como a «su relación con los publicanos y pecadores, a su personalidad tal como brilla en los Evangelios... el Símbolo es incompleto...» (A. Harnack, o.c., 34). Lo es también, respecto a la profesión de fe «en Dios Padre» y «en el Espíritu Santo»: Ambas confesiones pueden y deben ser ampliadas para el creyente hodierno. Nada de extraño, por otra parte. Si el Credo es «el compendio de la fe» así como «la síntesis de la teología» (Cf. supra, 4-7), la renovación de aquélla y ésta - promovida sobre todo por el Conc. Vat. II- postula una renovación correspondiente del Símbolo: ¡Sus vetustos y sólidos sillares, — de imperecedera validez-, exigen ser hoy remodelados, para servir adecuadamente al renovado edificio de la Iglesia hodierna! Así lo reconoció un ilustre teólogo católico, y hoy pastor de la Iglesia, cuyos análisis sobre la necesidad de redactar nuevamente el Credo (Cf. K. Lehmann, Bedarf das Glaubensbekenntnis einer Neufassung?: AA.VV., «Veraltetes Glaubensbekenntnis?», Regensburg 1968, 125-186; Cf. también: K. Rahner, La necesidad de una «fórmula breve» de la fe cristiana, en: Conc. 3 [1967] 450-465; Id., fórmulas breves de la fe: «Curso fundamental de la fe», 515-527; G. Baum, A new Creed, en: The Ecumenist 6 [1968] 164-167), desembocan en una respuesta del todo afirmativa: «Sí, pues mediante nuevas fórmulas de fe concentradas y concentradoras, puede la Confesión de Fe ser decisivamente completada, respectivamente aligerada, debiendo asimismo aquélla ser acompañada -más que hasta el presente- por una explicación fundamentalmente teológica, es decir, kerig- 


\section{CREO EN UN SOLO DIOS, -PADRE, HIJO Y ESPÍRITU SANTO-, QUE ES AMOR:}

-En EL PADRE, quien sólo por su amor engendra eternamente al Hijo, procediendo de ambos también por amor el Espíritu Santo, de modo que en estas tres distintas Personas divinas venero y adoro la unidad en la trinidad y la trinidad en la unidad. Por amor creó asimismo el «Padre omnipotente» -mediante el Hijo en el Espíritu Santo- todos los seres visibles -entre los cuales y como su cúspide al hombre, creado a su imagen y semejanza con un alma espiritual e inmortal- e invisibles, es decir, a los ángeles.

-Y en UN SOLO SEÑOR NUESTRO, JESUCRISTO, el unigénito Hijo de Dios, nacido eternamente del Padre como su Palabra viviente, por quien y para quien todo fue creado. El cual, por la salvación de todos los hombres:

Fue enviado por el Padre, - al llegar la plenitud de los tiempos-, y se encarnó por obra del Espíritu Santo en el seno de María siempre Virgen, - por ello devenida verdadera Madre de Dios-; y, uniendo sustancialmente la asumida naturaleza humana a su Persona divina, devino verdadero hombre y asumió la condición de Siervo, semejante en todo a nosotros excepto en el pecado. Llamado por el Padre - en su bautismo- a cumplir la misión salvífica de su preanunciado Siervo mesiánico, anunció e inauguró en la tierra -mediante palabras y signos salvadores- el Reinado de Dios, manifestando asimismo el gratuito amor del Padre a los pecadores y fundando - en sus discípulosla Comunidad escatológica del nuevo Israel. En obediente cumplimiento del salvífico designio del Padre sobre su Siervo sufriente, que «por nuestras rebeldías fue entregado a la muerte», sufrió voluntariamente - bajo Poncio Pilato- una ignominiosa pasión, «haciéndose obediente hasta la muerte y muerte de cruz», - no sin darnos antes a su Madre por Madre nuestra, la Madre de la Iglesia-; fue sepultado y descendió a los infiernos o morada de los muertos, en signo de solidaridad con ellos así como de su expiación universal y de su señorío sobre la muerte. Al tercer día - en cumplimiento de las Escrituras- resucitó victorioso de entre los muertos como «Espíritu vivificante», dando a cuantos creen en Él participar de su triunfo sobre toda realidad de sufrimiento y de muerte. Pues, tras habernos dejado en el sacramento de

máticamente orientada» (K. Lehmann, a.c., 184s). Se cumprende, en este sentido, el reitelauo intento por formular nuevamente el Credo, tal como se refleja en las «modernas confesiones de fe» aparecidas en las últimas décadas (Cf.: G. Ruhbach-H. Schröder-M. Wichelhaus (Hrsg.), Bekenntnis in Bewegung, Göttingen 1969; R. Bleistein, Kurzformel des Glaubens, II: Texte, Würzburg 1971, 20-85 [el a. reproduce 70 Credos modernos]; H. Schröer, Unser Glaubensbekenntnis heute. Versuch einer theologischen Bilanz, Hamburg 1970, 35s). A ese intento se suman las reflexiones de K. Rahner sobre la exigencia hodierna de nuevas y diversas «fórmulas breves de la fe» (loc. cit.): Puesto que «el Símbolo apostólico... no puede hoy ejercer en forma suficiente la función de tal fórmula fundamental, pues llama de manera poco inmediata en la actual situación espiritual», existe «la necesidad de diversas fórmulas fundamentales» de la fe, las cuales, conservando la validez del «Símbolo apostólico» y en correspondencia con la legítima «pluralidad insuperable de teologías», contengan «solamente lo que reviste importancia decisiva y es la base desde la cual en principio puede alcanzarse el todo de la fe», es decir, sean «un punto de partida - prometedor de éxito- para la inteligencia de toda la fe cristiana»: O.c., 516-520. 
la eucaristía el memorial de su muerte y resurrección, fue exaltado por el Padre a la gloria celeste, - a la que fue asociada ya en cuerpo y alma María-, siendo constituido asimismo Señor y Salvador de cuantos con fe invocan su nombre, así como Iuez de vivos y muertos Para realizar este juicio universal, vendrá de nuevo al final de los tiempos, -cuando «el Evangelio haya sido anunciado en todo el mundo»-, pidiendo a cada uno cuenta de sus talentos recibidos y retribuyéndoles - según sus méritos- con el don de la vida eterna o el castigo de la condenación sin fin.

-Y en EL ESPÍRITU SANTO, Señor y vivificador. Él habló por los proretas, realizó la encarnación del Hijo de Dios en el seno de María y lo ungió con la plenitud de sus dones a raíz del bautismo, para que - a impulso suyo- realizase la obra salvadora. Efundido por el Señor glorificado sobre su Comunidad mesiánica, para que fuese testigo suyo «hasta los confines de la tierra», dio así origen a la Iglesia. A ésta ilumina con su luz, - para que sea indefectible en la Verdad-, y con la gracia - comunicada por la Palabra, la oración y los sacramentos- la santifica, para que sus miembros crezcan en santidad, se amen como Cristo los amó y - aunados en este amor- Le manifiesten al mundo, a fin que éste crea en Él y se salve. Sacramento de salvación universal es, en efecto, la Iglesia, fundada por Cristo - mediante el Espíritu Santocomo su Cuerpo místico, la Casa de Dios edificada sobre el fundamento de los Apóstoles, el nuevo y peregrinante Pueblo de Dios regio, sacerdotal y profético; visiblemente constituida como Sociedad de la caridad, está integrada por todos los creyentes en Cristo bajo la guía pastoral del sucesor de Pedro -el obispo de Roma- y de los Apóstoles - los obispos de las iglesias locales-, aunados aquél y éstos en la comunión del Colegio episcopal, del que aquél es la Cabeza. Todos ellos - con la colaboración de sus sacerdotes y diáconos- rigen, enseñan y santifican a la que es «Nación santa» y, sin embargo, - por encerrar en su seno a justos y pecadores- necesitada de incesante autoevangelización y conversión, «para evangelizar creíblemente al mundo» la Buena Noticia de la Salvación, mediante el perdón de los pecados. Todos los hombres, en efecto, pecan en Adán - con la excepción de María, «concebida sin pecado por privilegio divino en atención a los méritos de Cristo redentory- $-\mathrm{e}$ incurren en pecados personales, cuyo perdón es otorgado por la Iglesia inicialmente mediante el bautismo y, después de éste, mediante el sacramento de la reconciliación, siendo los pecados veniales purificados también per la súplica del perdón al Padre, «como nosotros perdonamos a nuestros deudores». Así ora diariamente la Iglesia, creyendo en la resurrección corporal de todos los muertos - al fin del mundo- y confesando su fe en la Vida eterna, de la que ya participa plenamente María y en la que, tras haber sido purificados de todo pecado en el purgatorio quienes con él mueran, participarán por don divino todos los «muertos en Cristo» así como cuantos encuentre creyendo en Él a su venida, siendo por el contrario los malvados, -que voluntariamente rechazaron Su amor-, condenados a un suplicio igualmente eterno:

AMÉN.

Esta re-formulación del Símbolo - me interesa subrayarlo- explicita y reinterpreta tanto el antiguo Símbolo bautismal como el posterior Credo nice- 
no y constantinopolitano: ¡No los sustituye! Aquél y éstos siguen siendo las imperecedas confesiones de $\mathrm{Fe}$, mediante cuya profesión se une el cristiano de hoy a la fe de toda la Iglesia antigua y hodierna. No se trata, pues, de sustituir sino de reinterpretar el Credo recibido para, reinterpretado u hodiernizado, comunicarlo a nuestra generación cristiana y trasmitirlo a la venidera, contribuyendo así a unirla con toda la cristiandad en la confesión del Dios uno y trino: ¡La única confesión capaz de «formar unos cristianos firmes en lo esencial y humildemente felices en su fe» ? $^{92}$. Sólo esa fe, vertebrada en la espina dorsal del Símbolo ${ }^{93}$, hace de aquéllos unos creyentes adultos y, en calidad de tales, valientes confesores de Cristo, es decir, testigos ante el mundo del gratuito e indecible amor del Padre a los pecadores, manifestado en la entrega redentora de su Hijo y comunicado -en y por la Iglesia - mediante el don vivificante de su Espíritu.

92. Juan Pablo II, Exh. Apost. CT IX 61. 93. Cf. supra, 8s. 